\title{
Angucyclinone Antibiotics: Total Synthesis of
}

\author{
YM-181741, (+)-Ochromycinone, (+)- \\ Rubiginone $\mathrm{B}_{2}$, (-)-Tetrangomycin and MM-
}

47755

Krishna P. Kaliappan* and Velayutham Ravikumar

Department of Chemistry, Indian Institute of Technology-Bombay, Powai, Mumbai 400076, INDIA

E-mail: kpk@chem.iitb.ac.in

\section{Supporting Information}

Spectral data for all new compounds................................. S2 - S63 

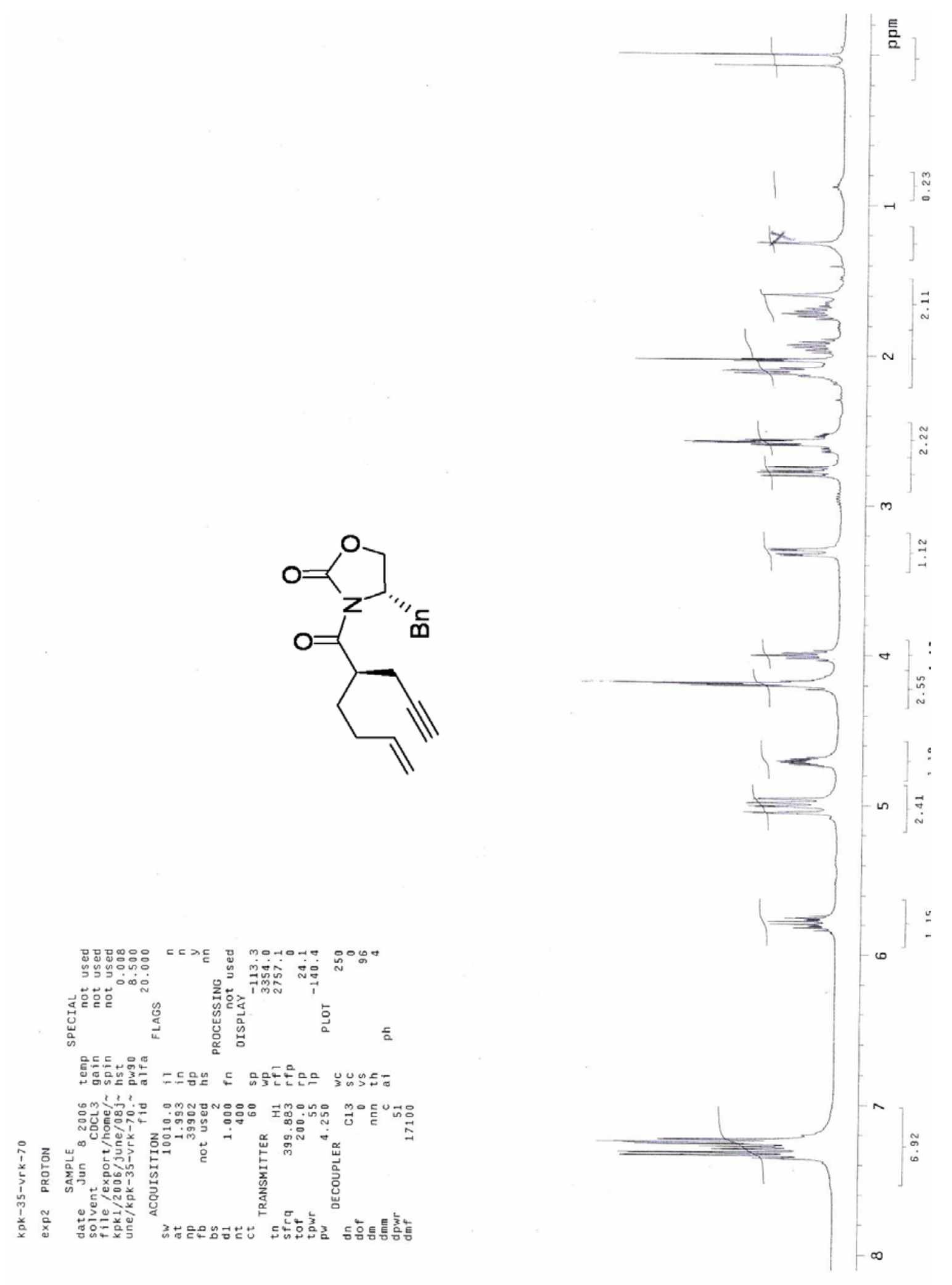


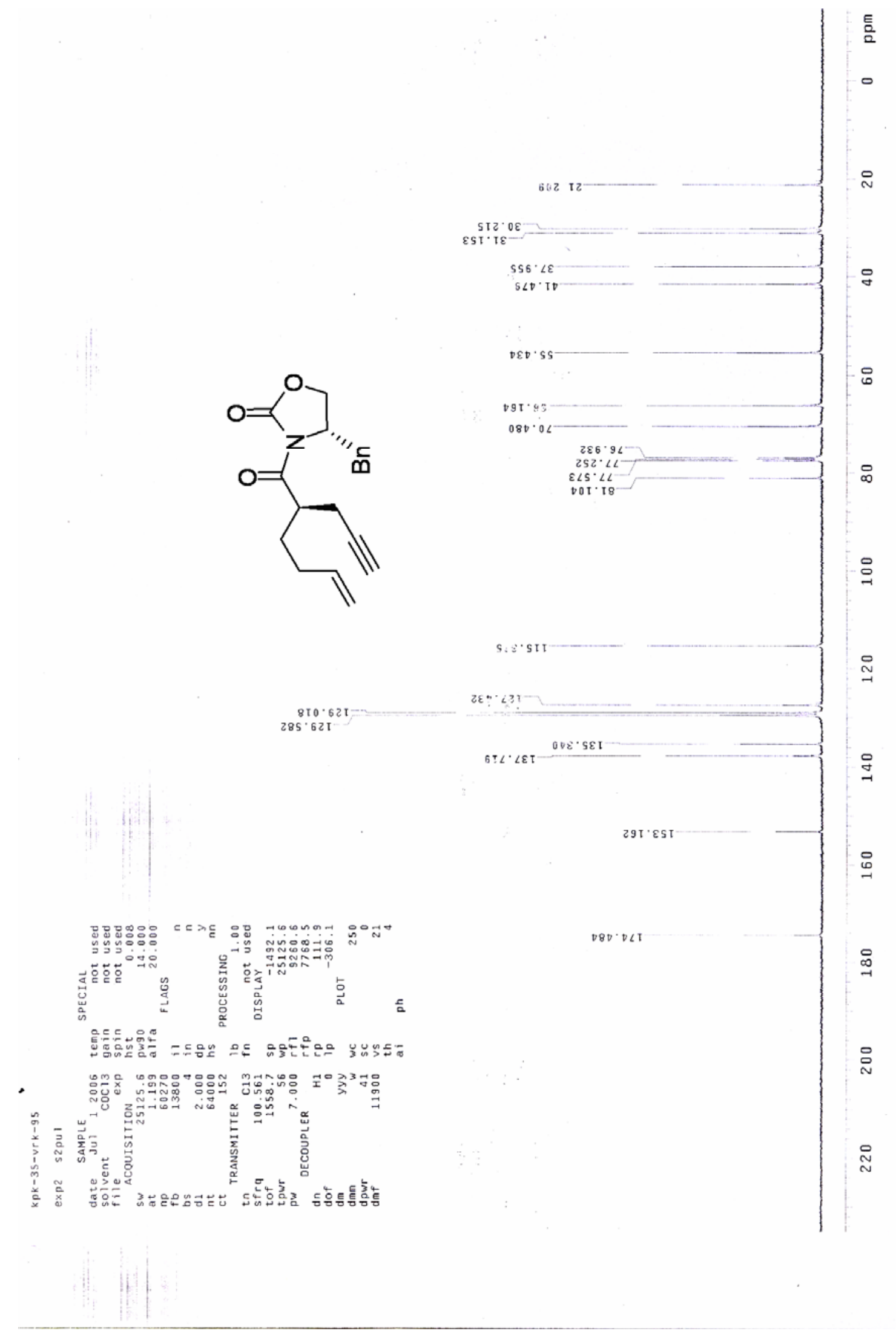




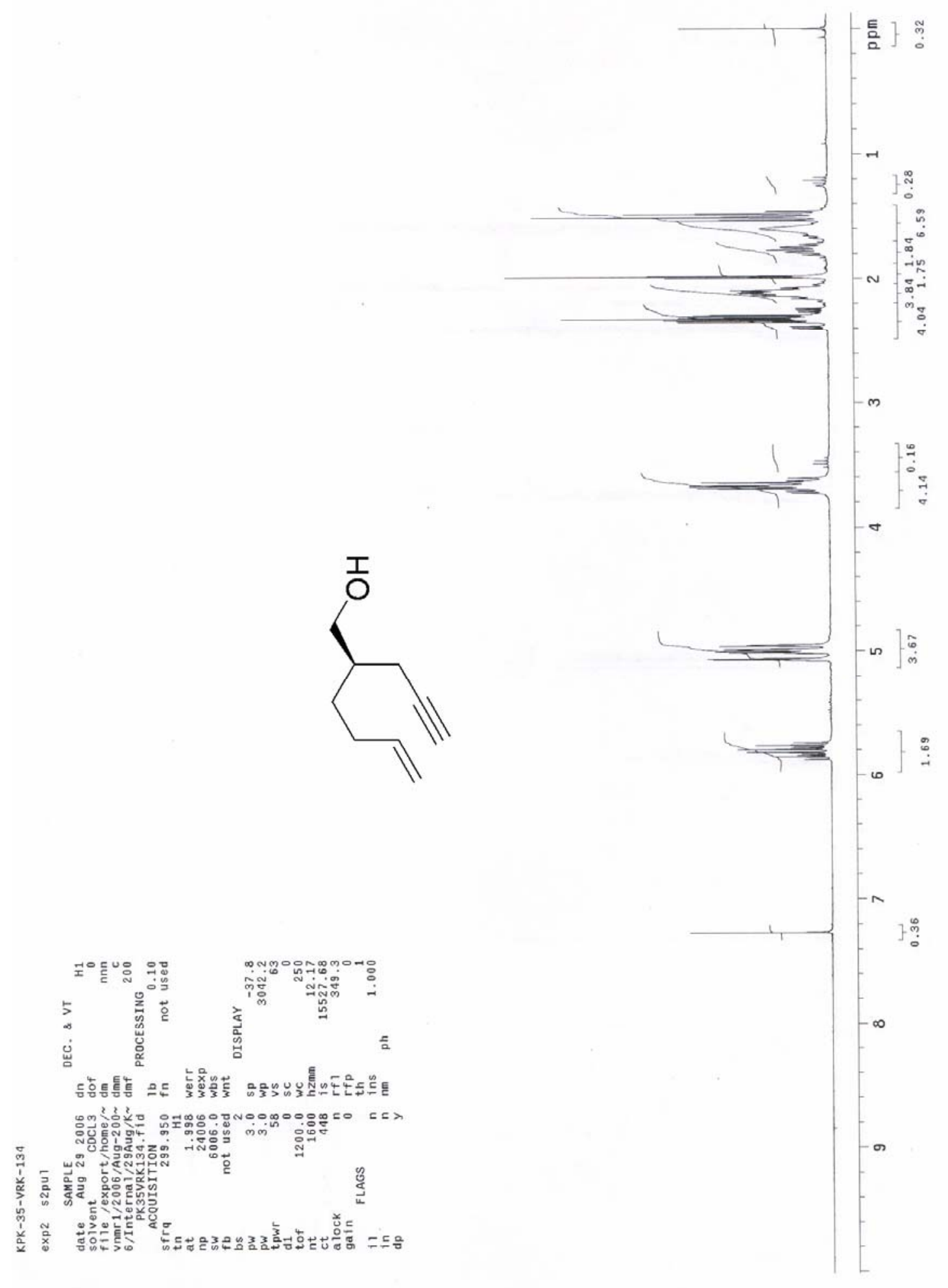




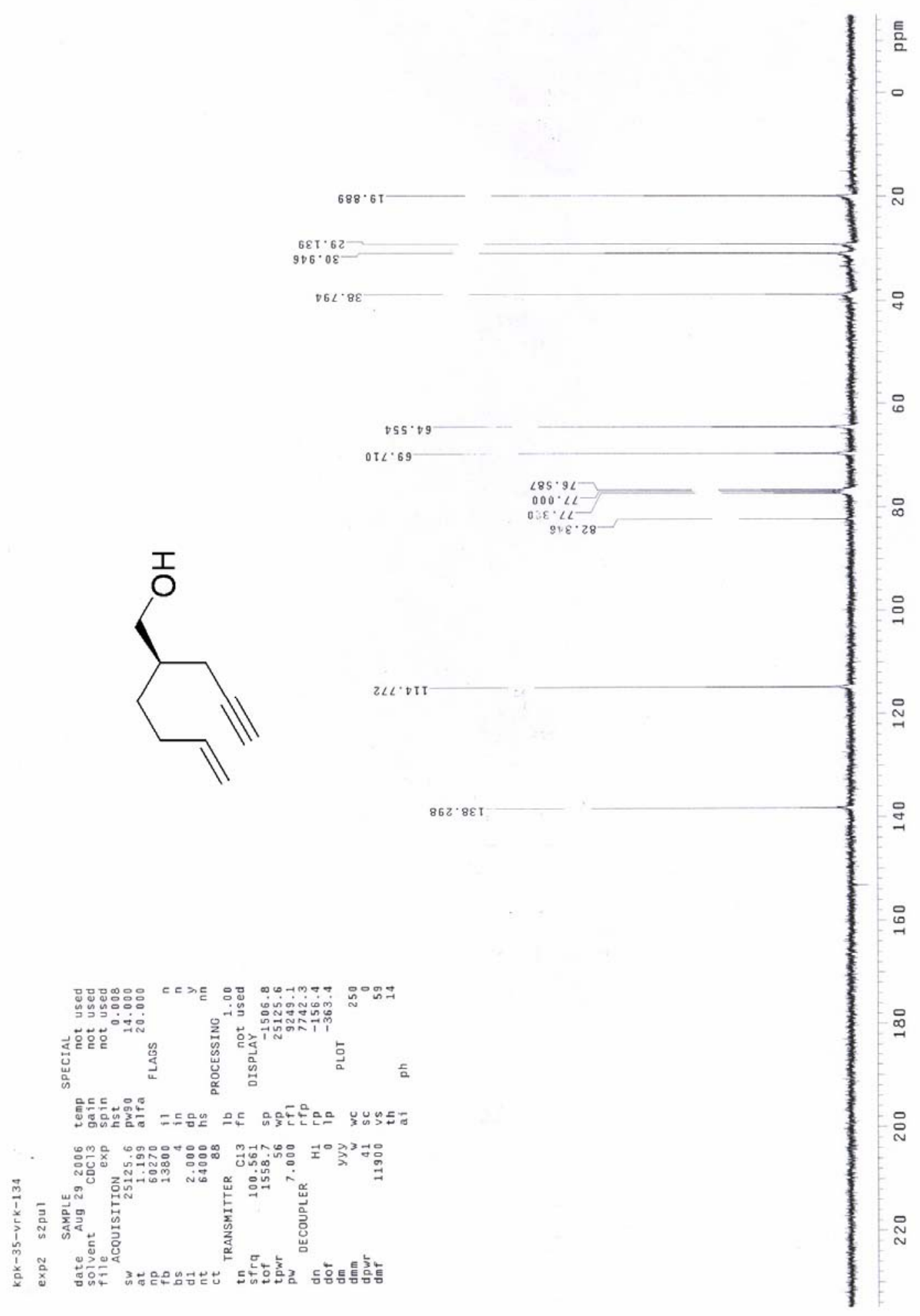




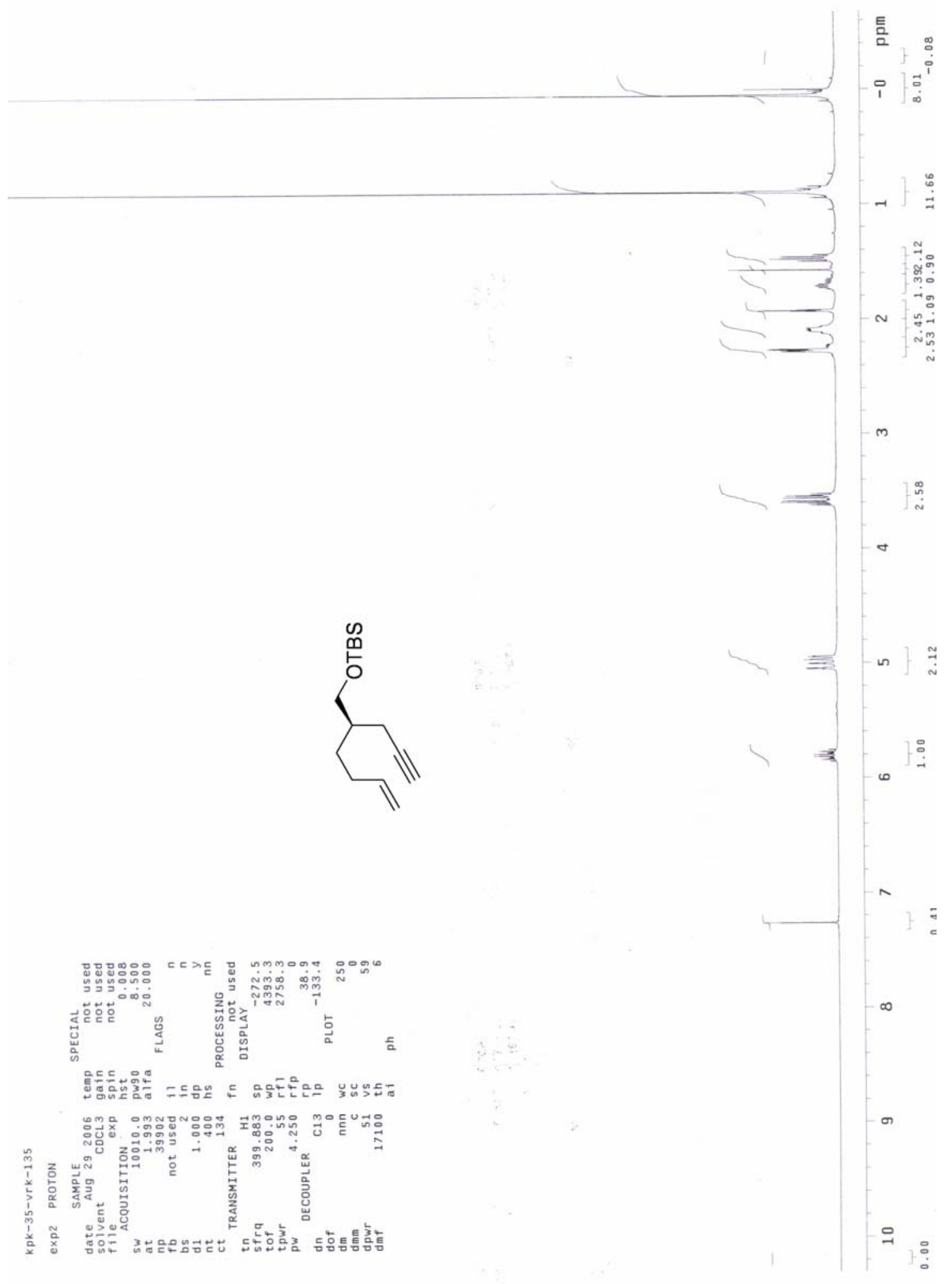




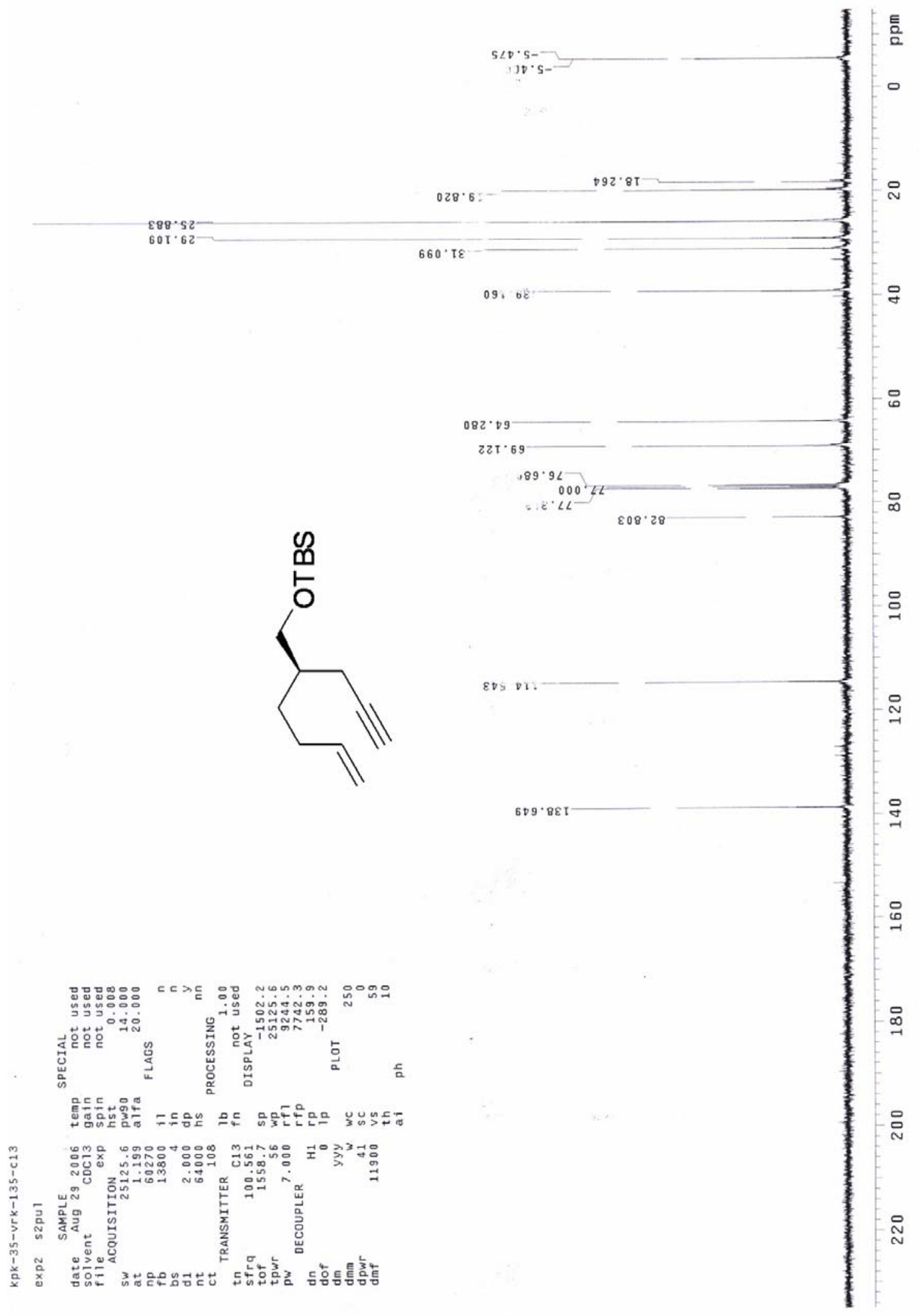




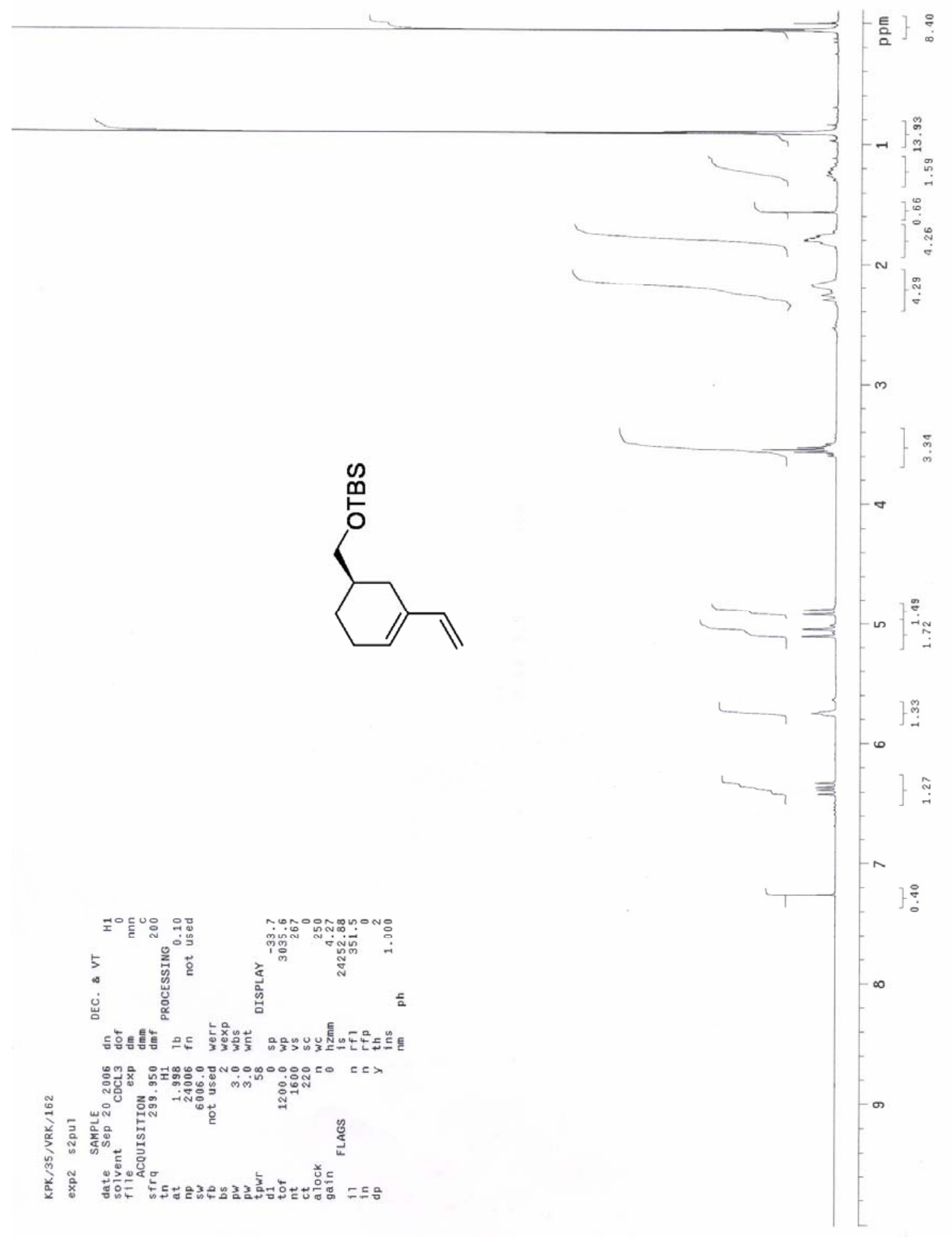




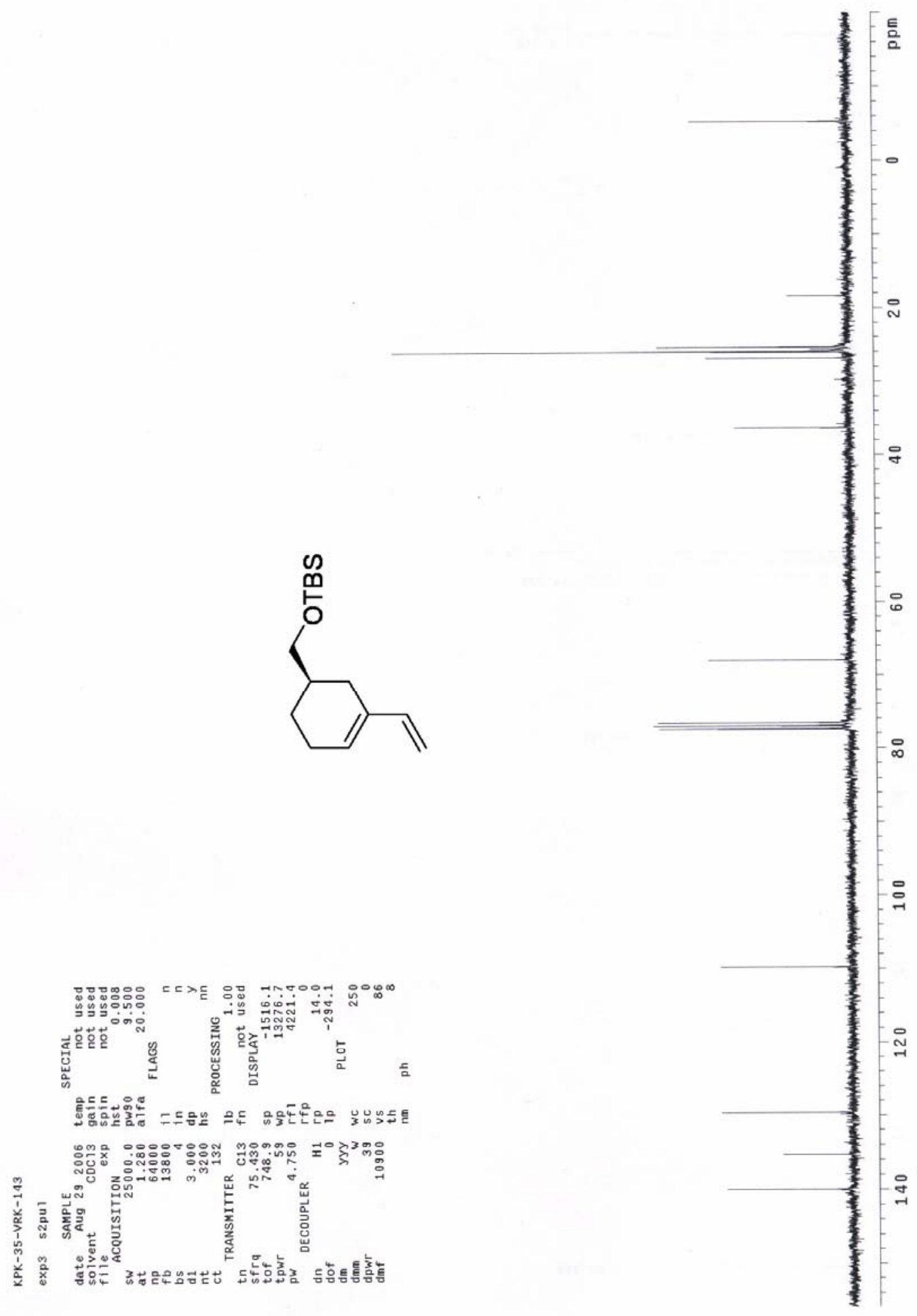




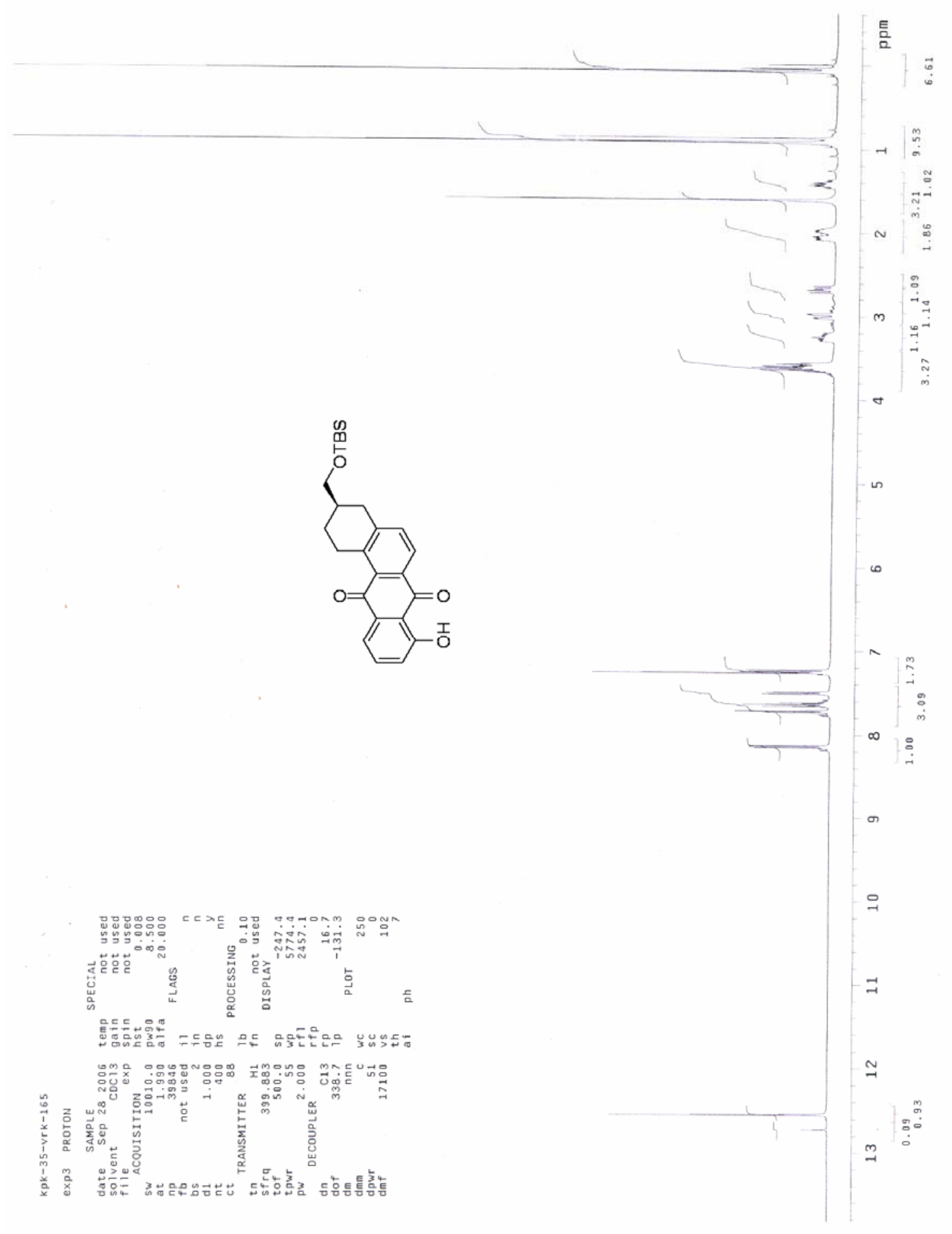




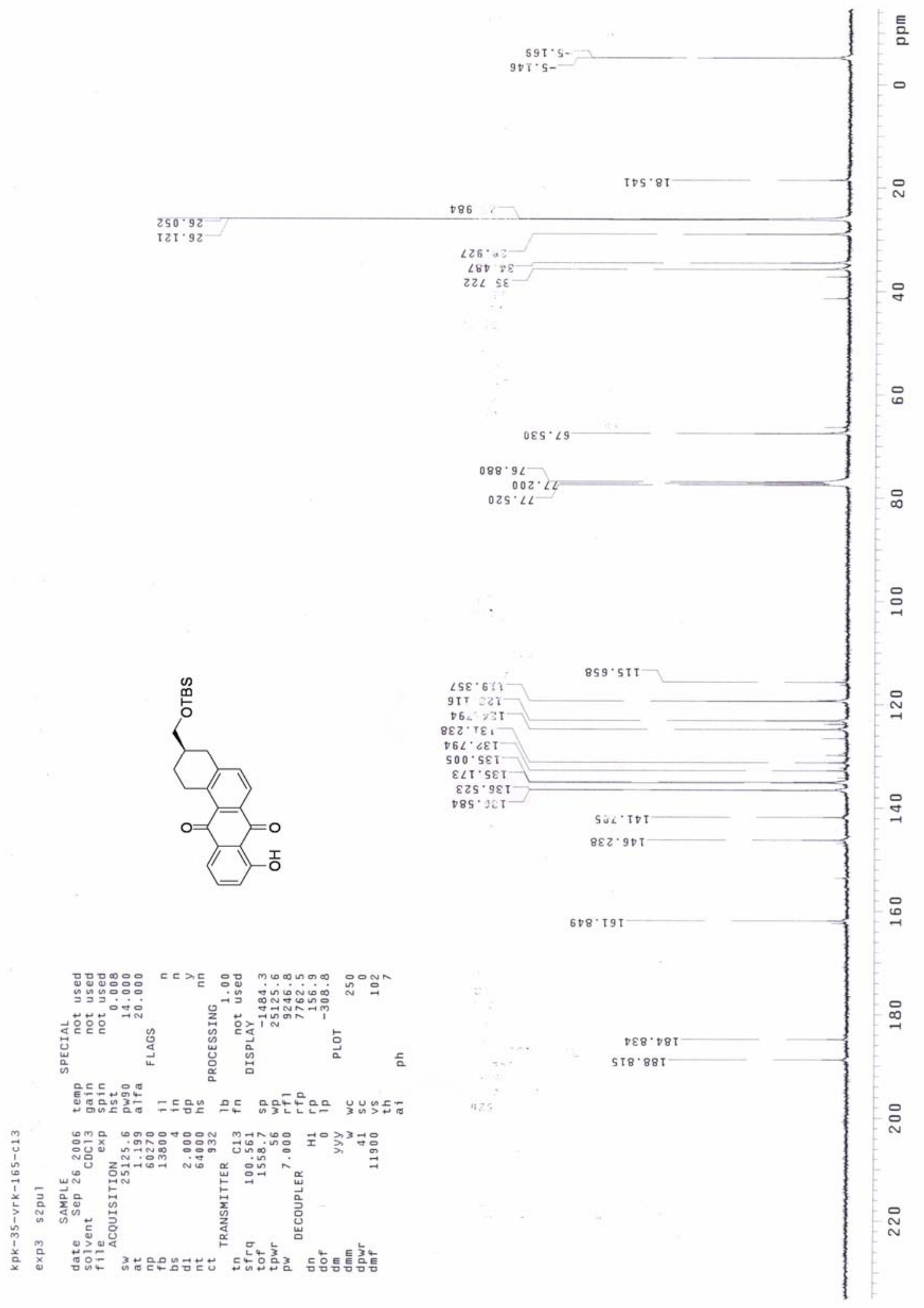




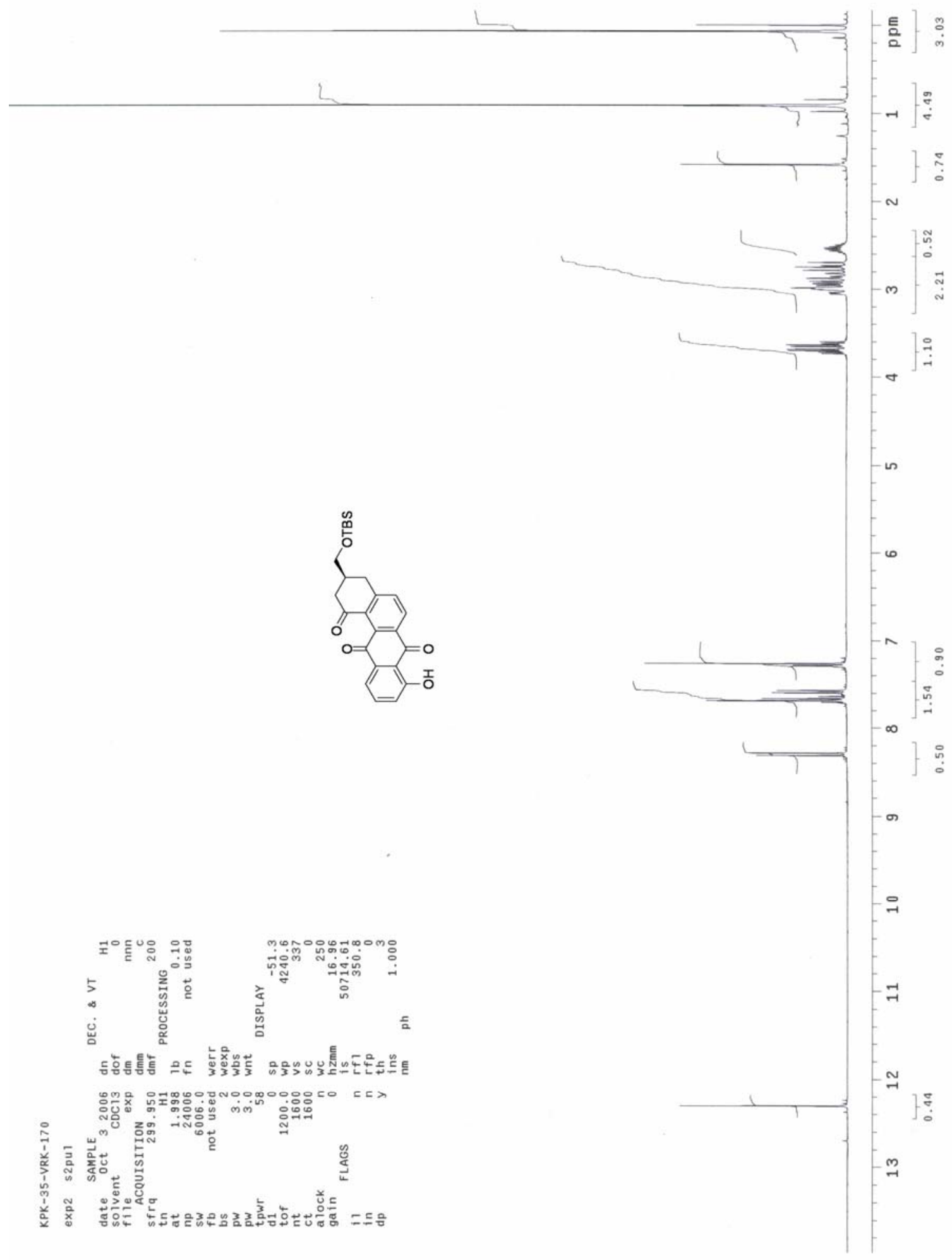



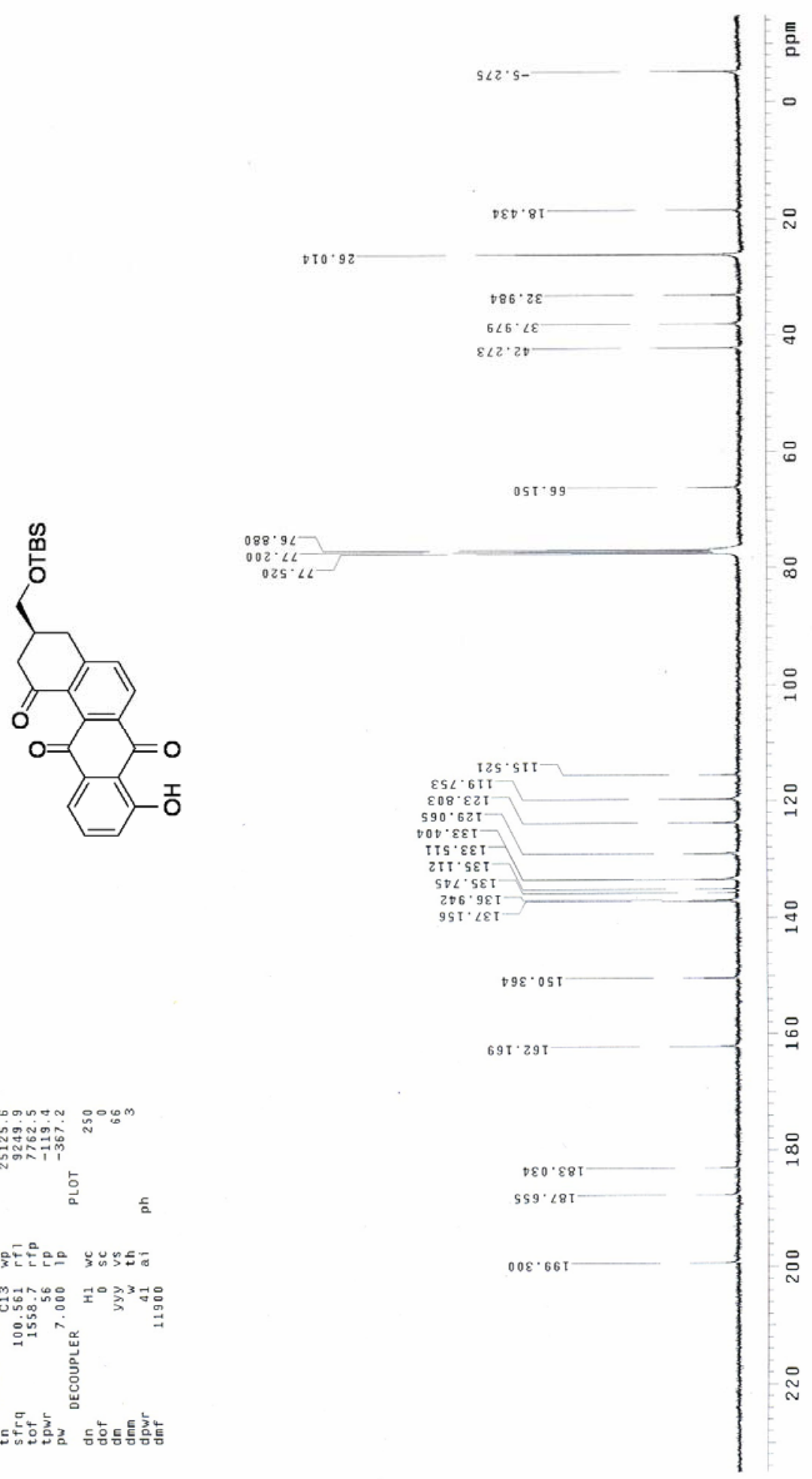


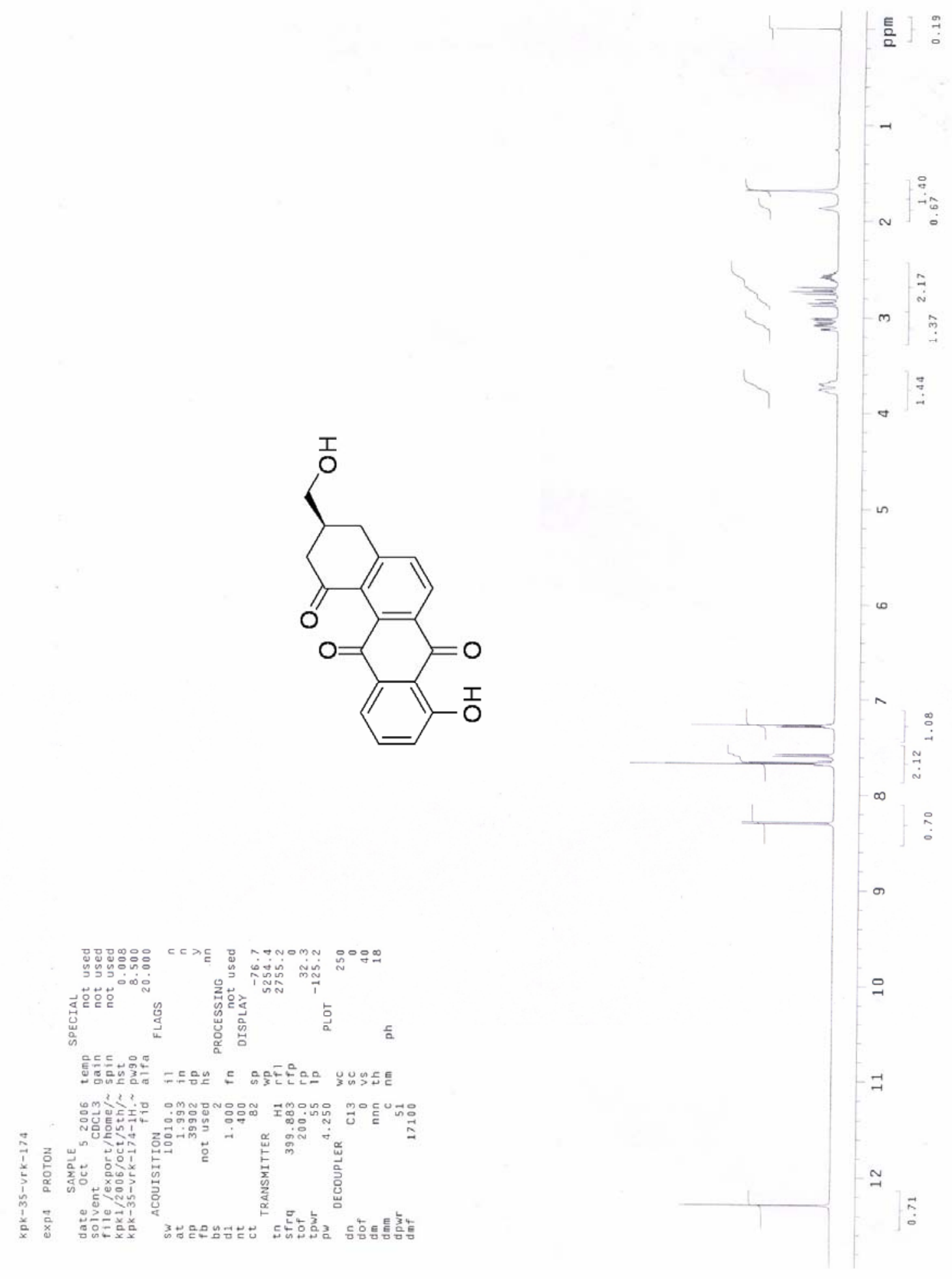




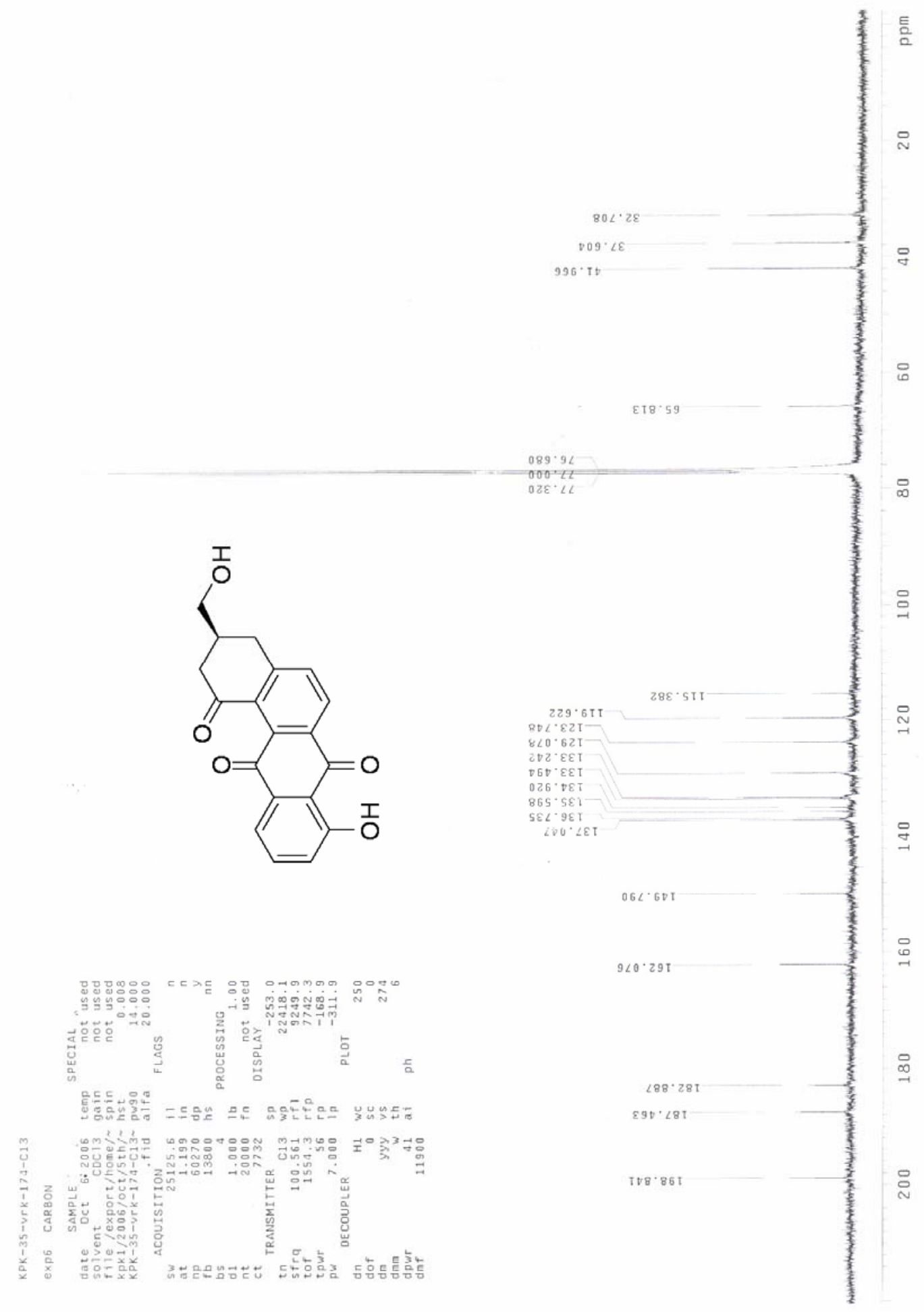



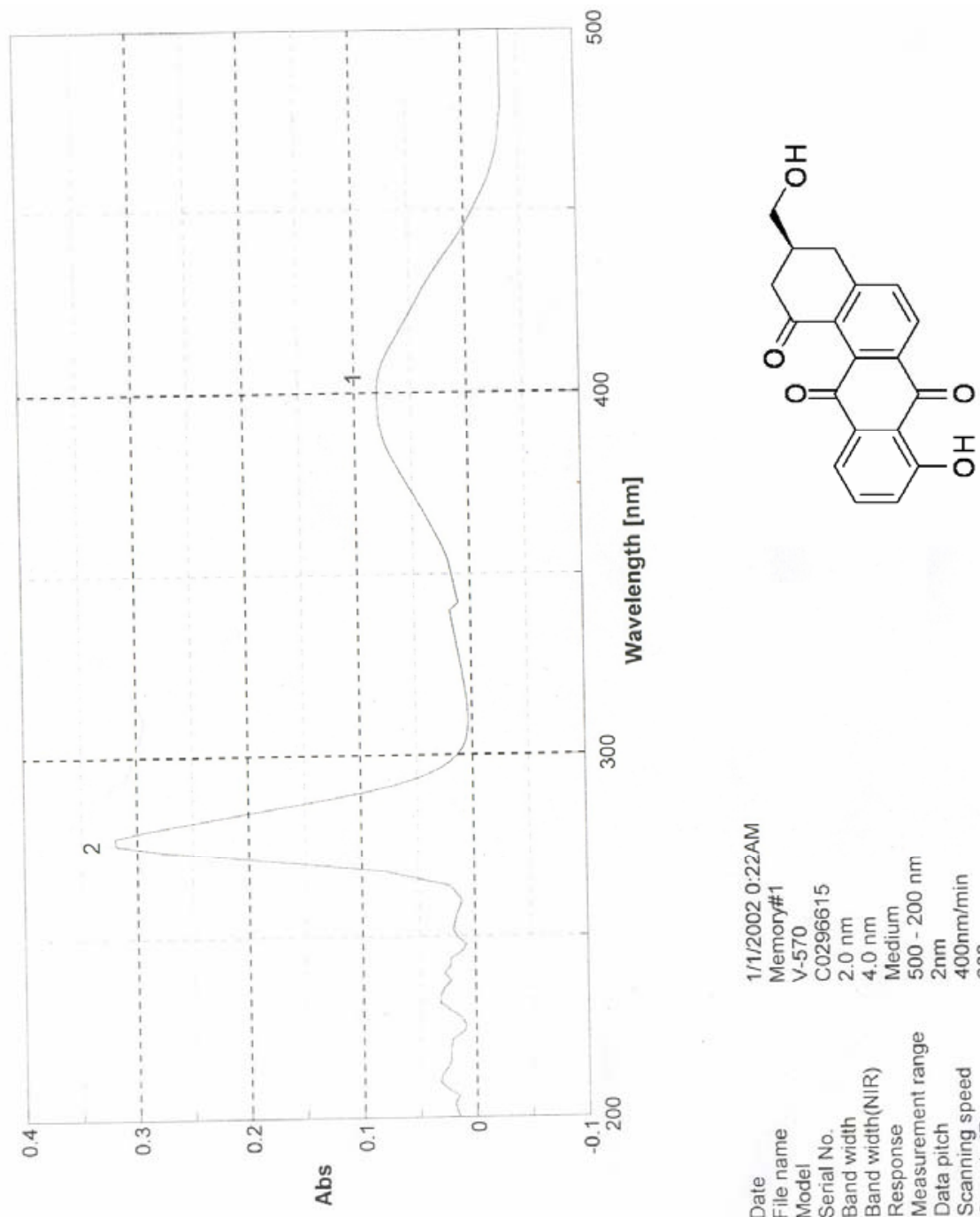

蒂

ㅌำ

$i^{N}$

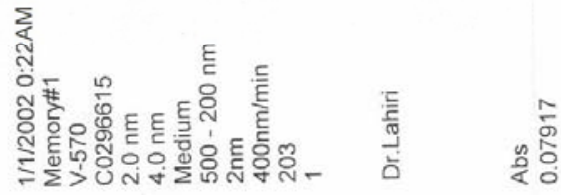

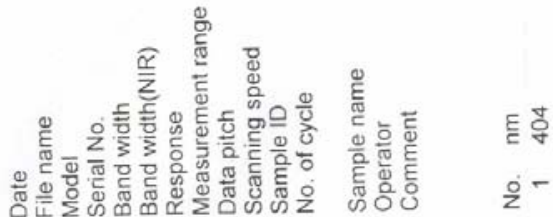




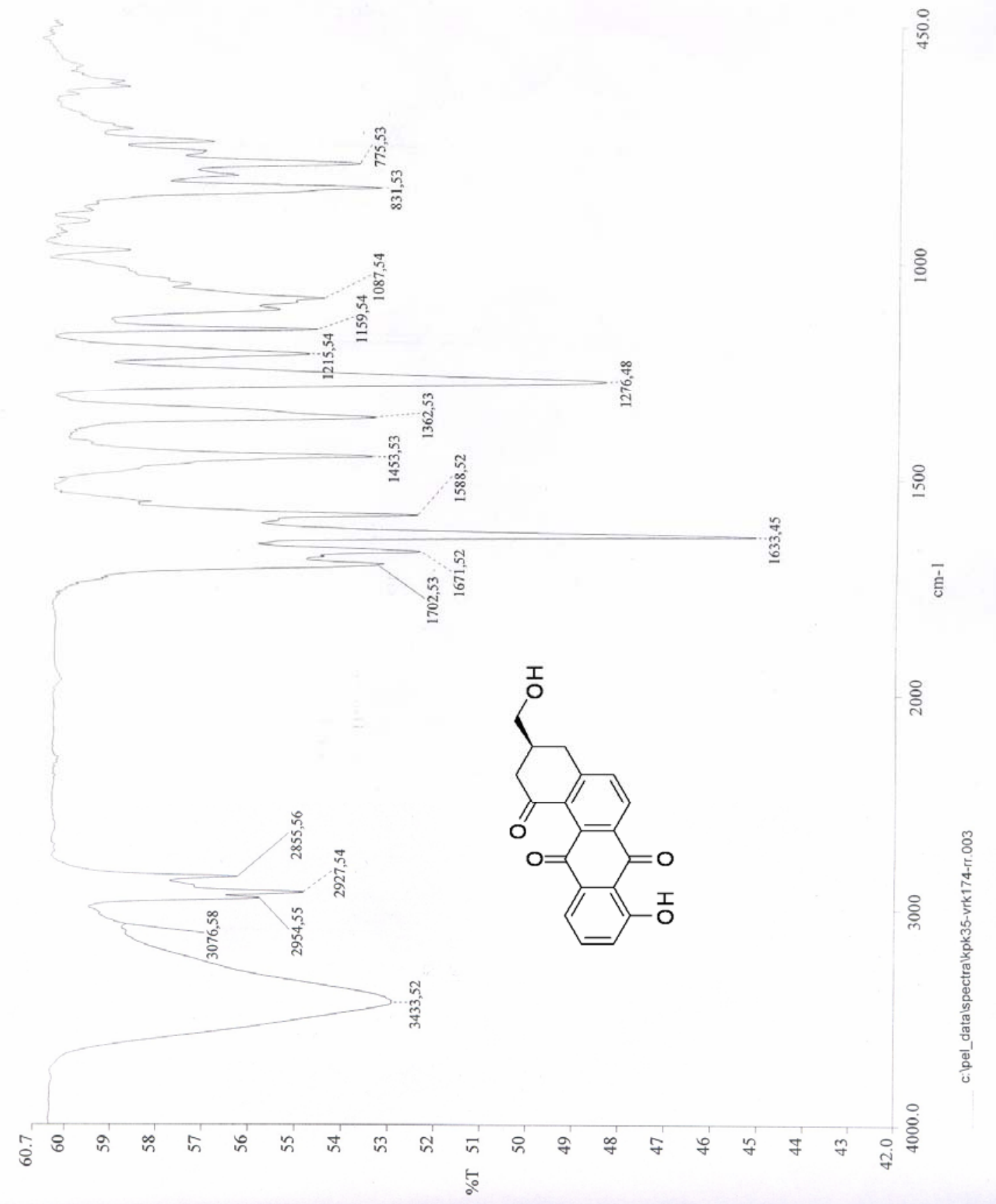



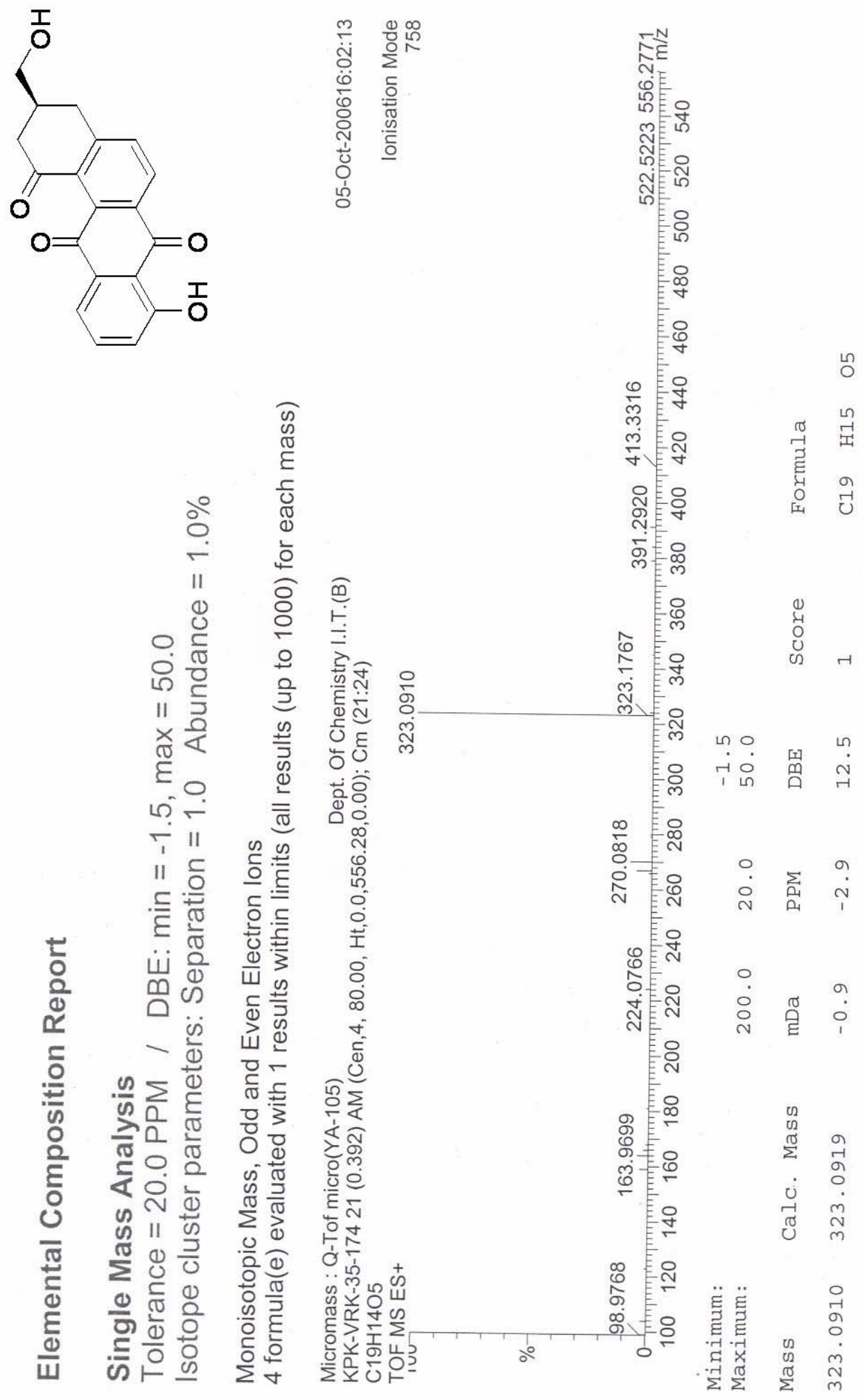


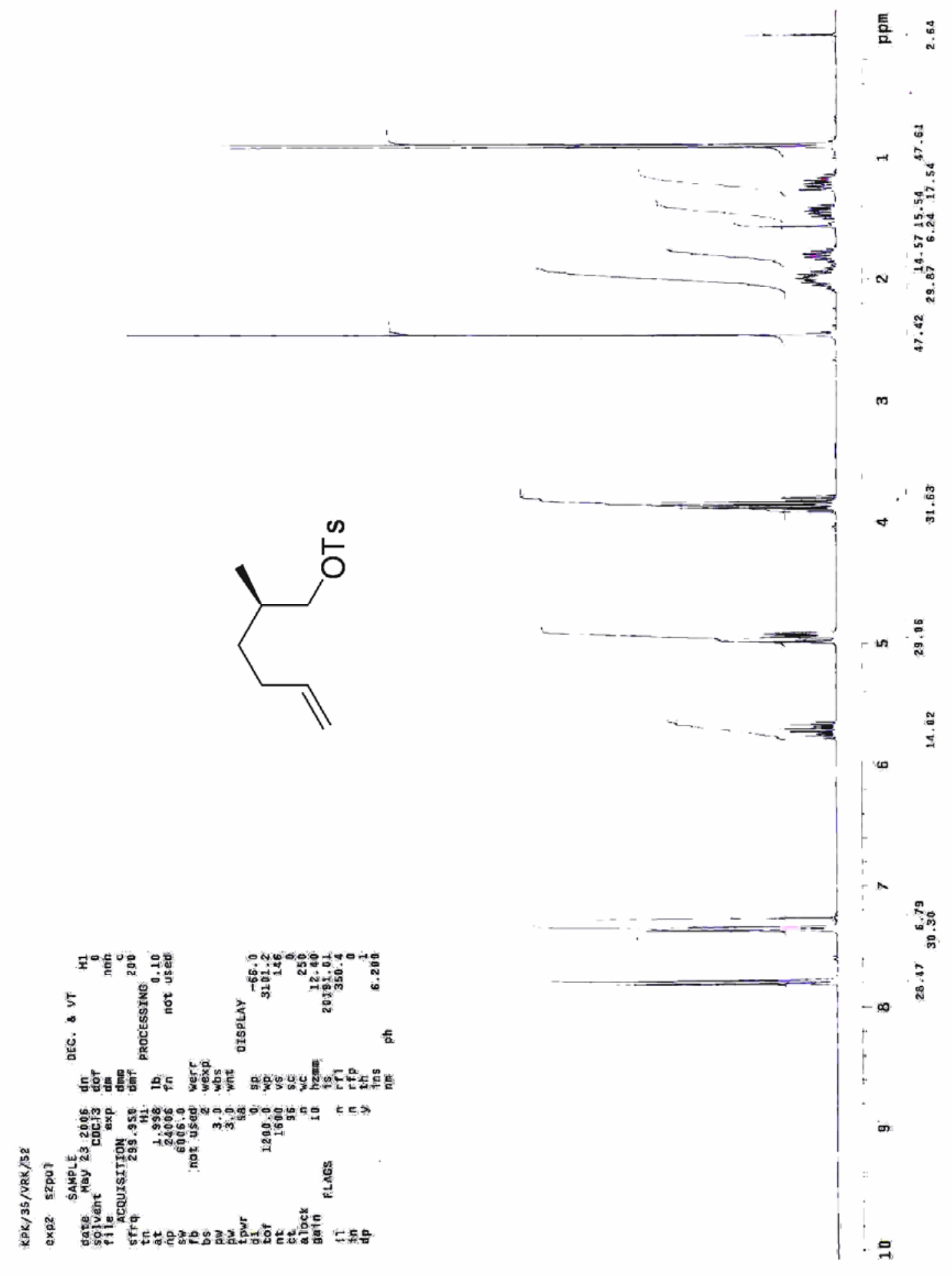




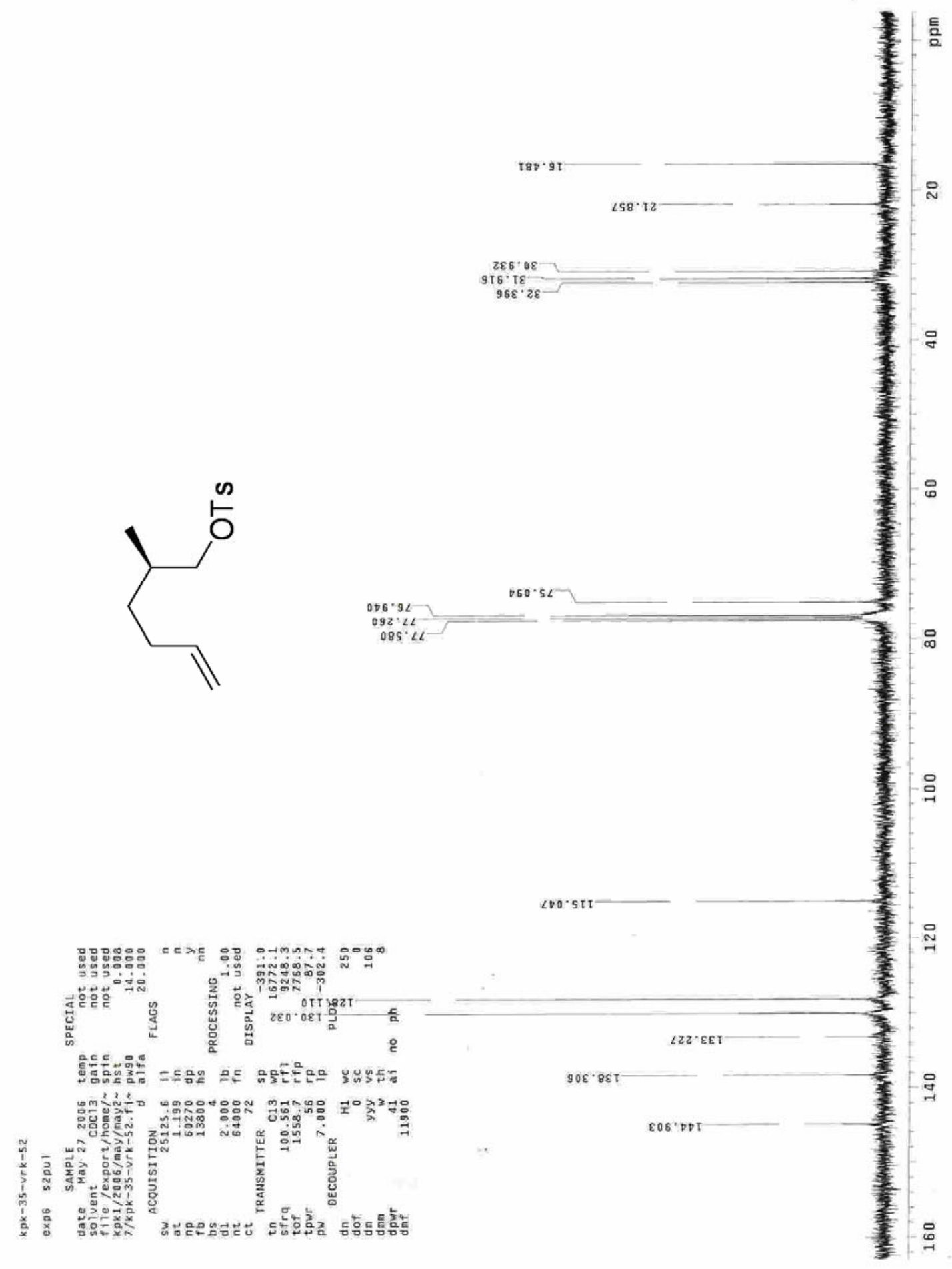



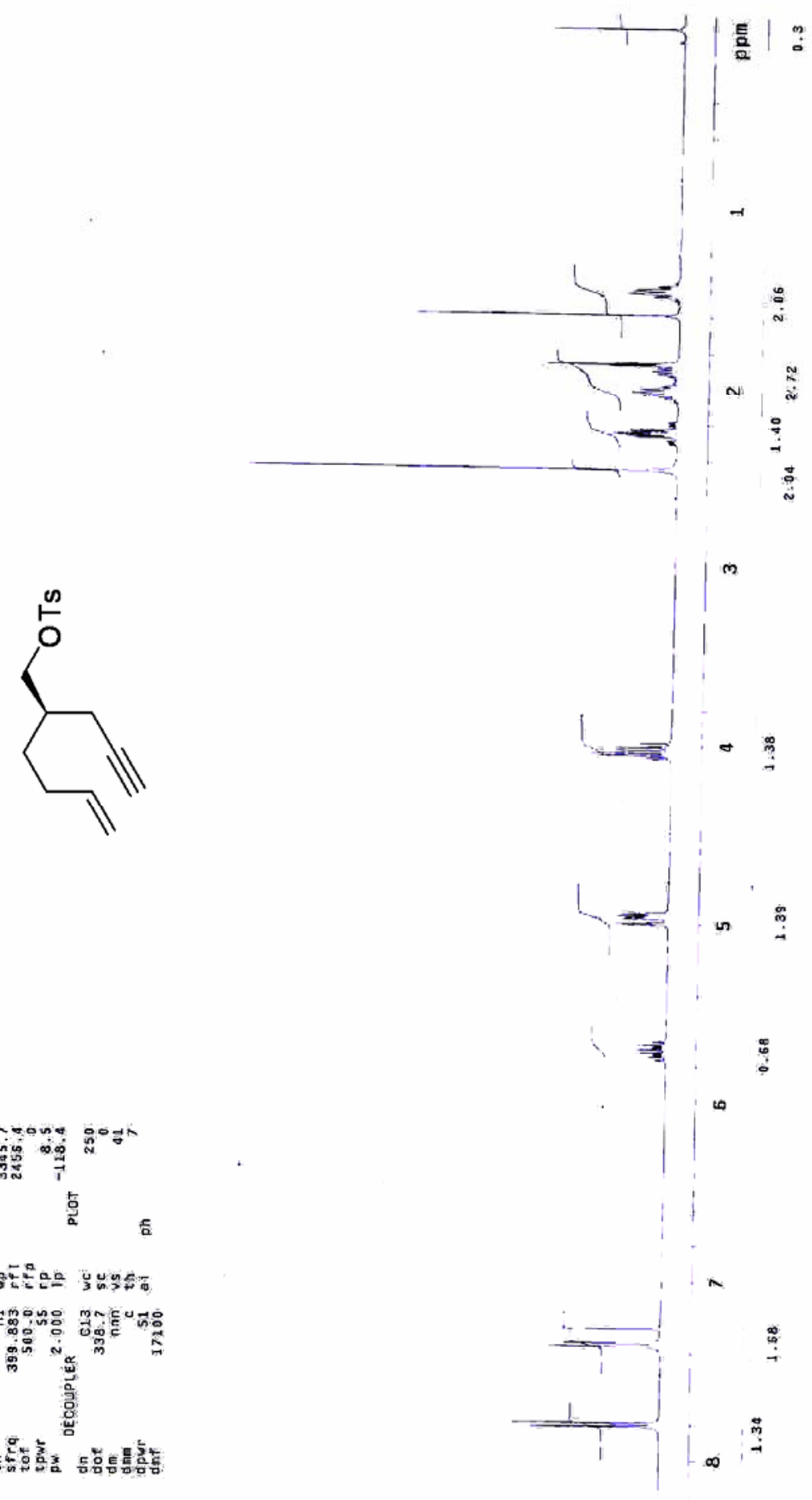


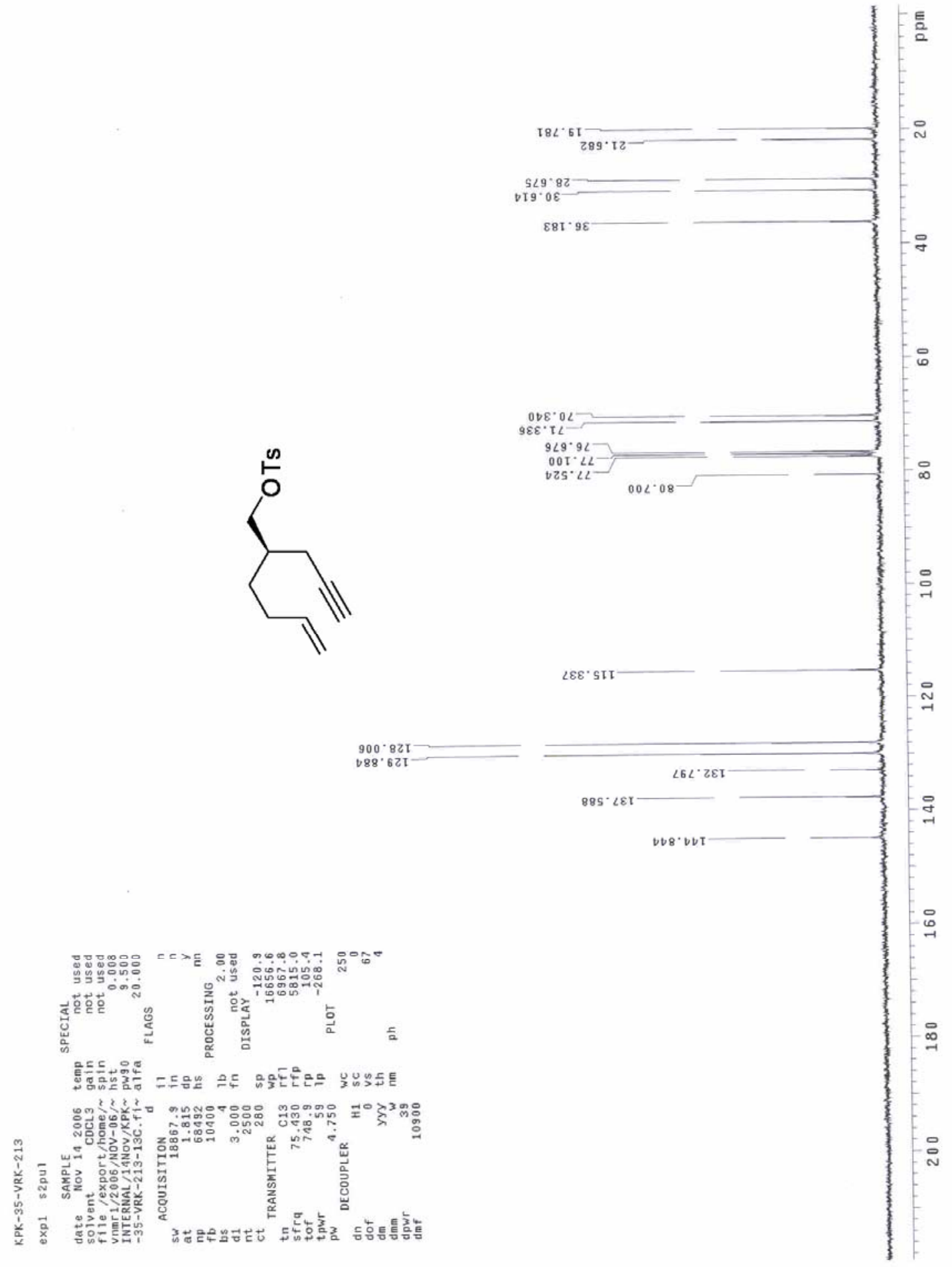




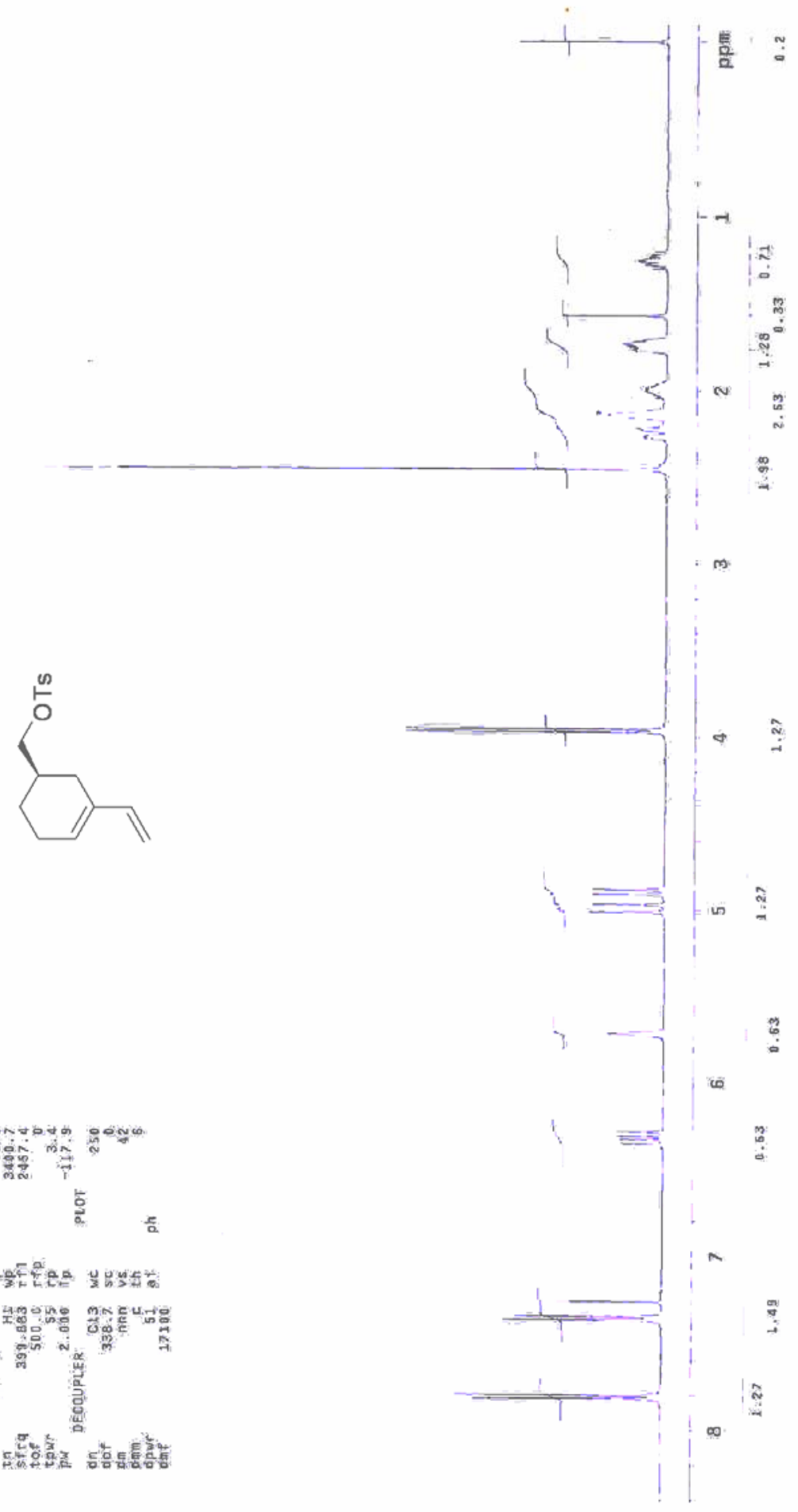




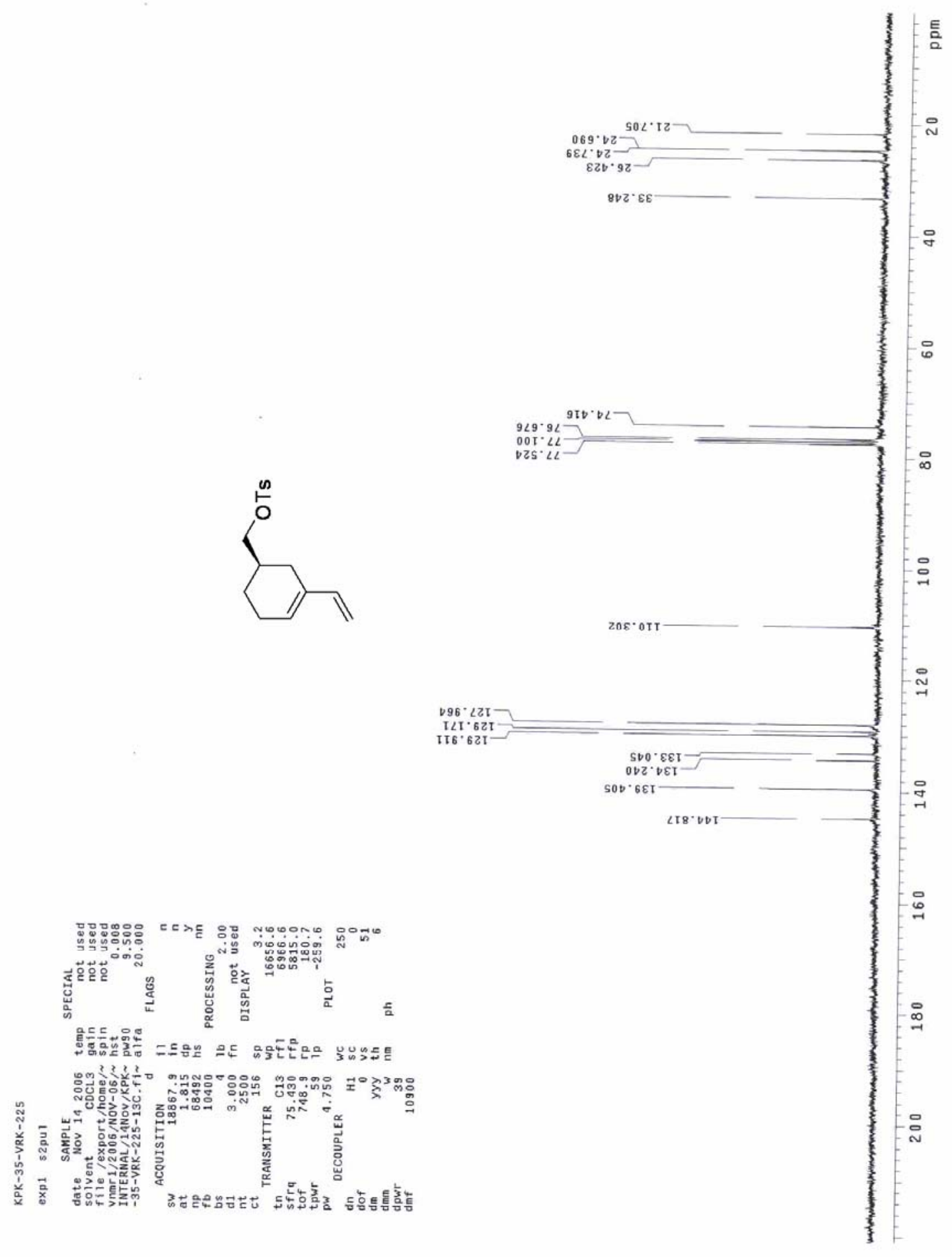




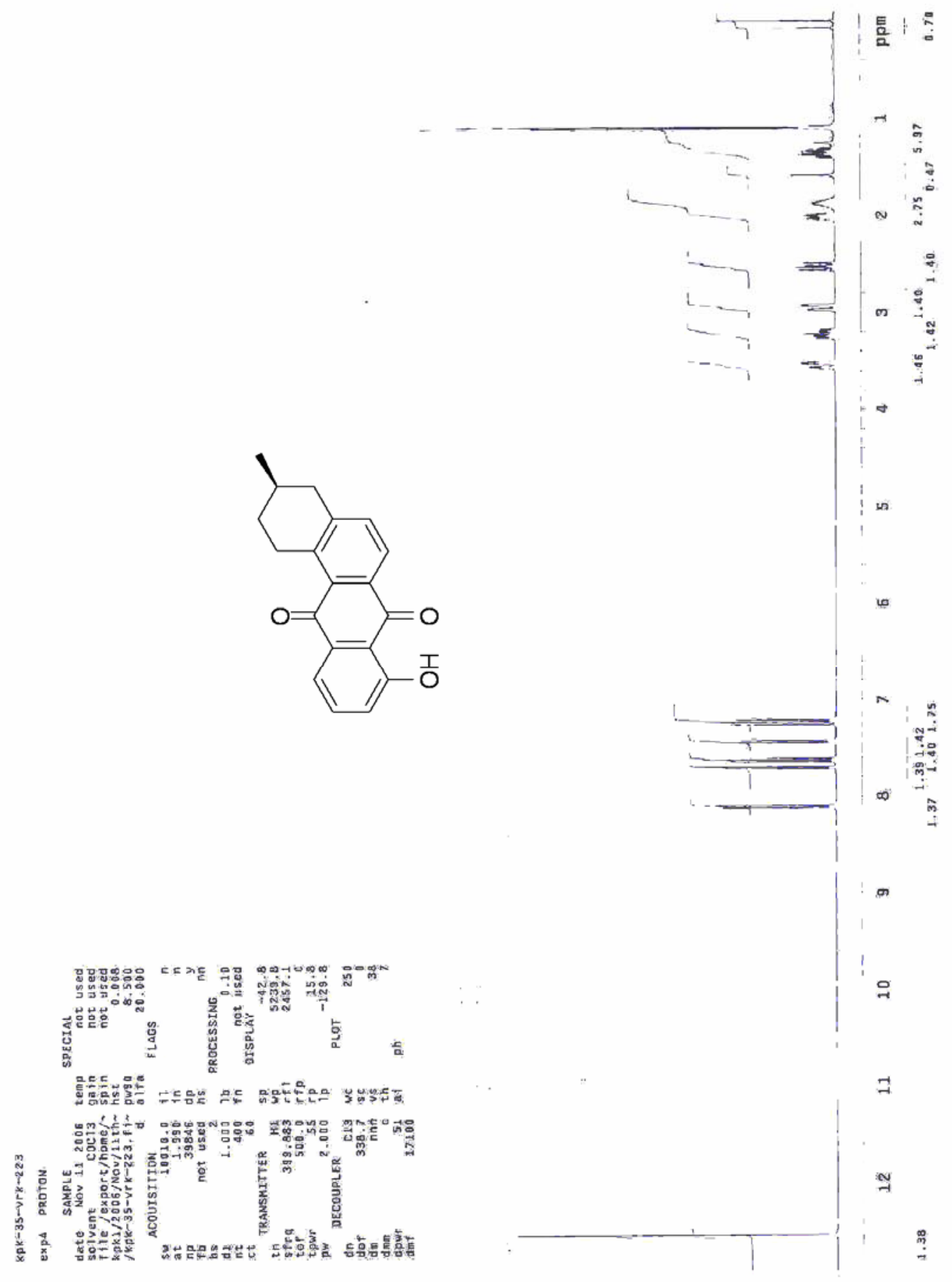




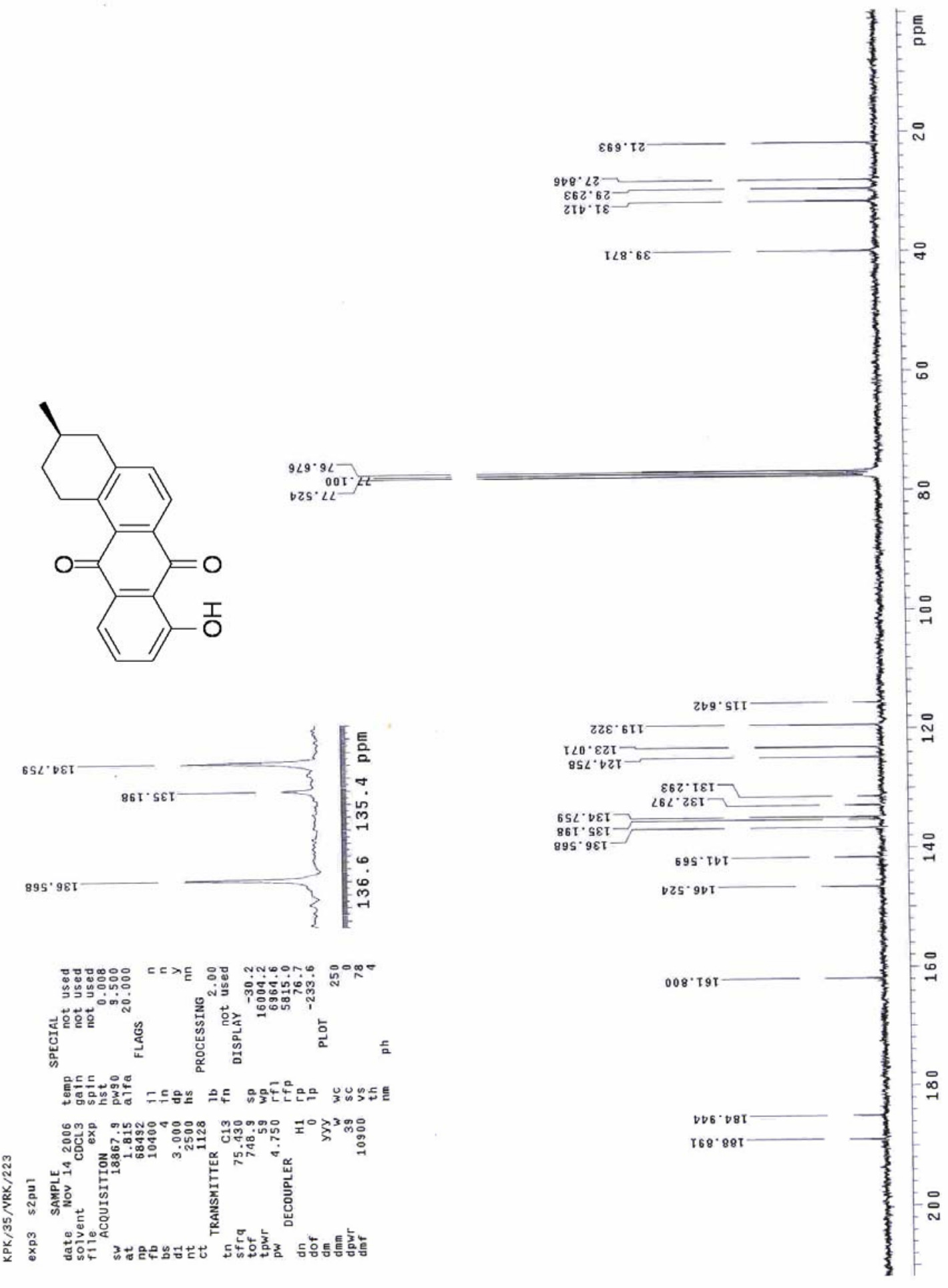



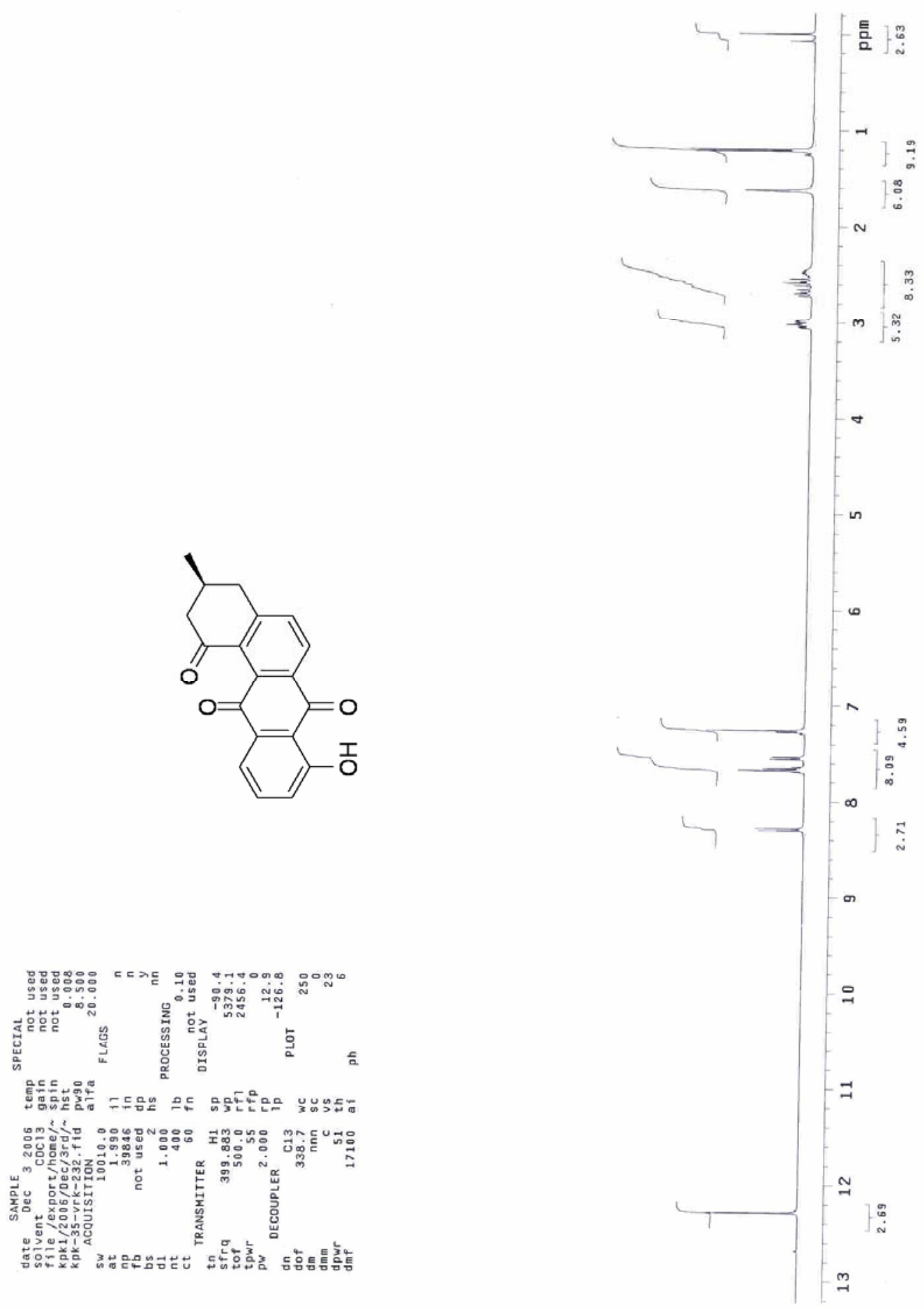

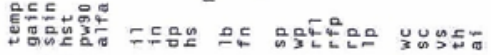

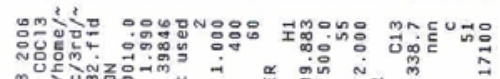

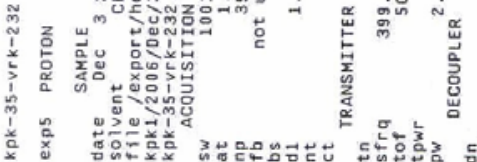

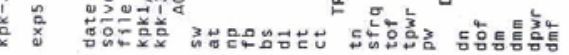




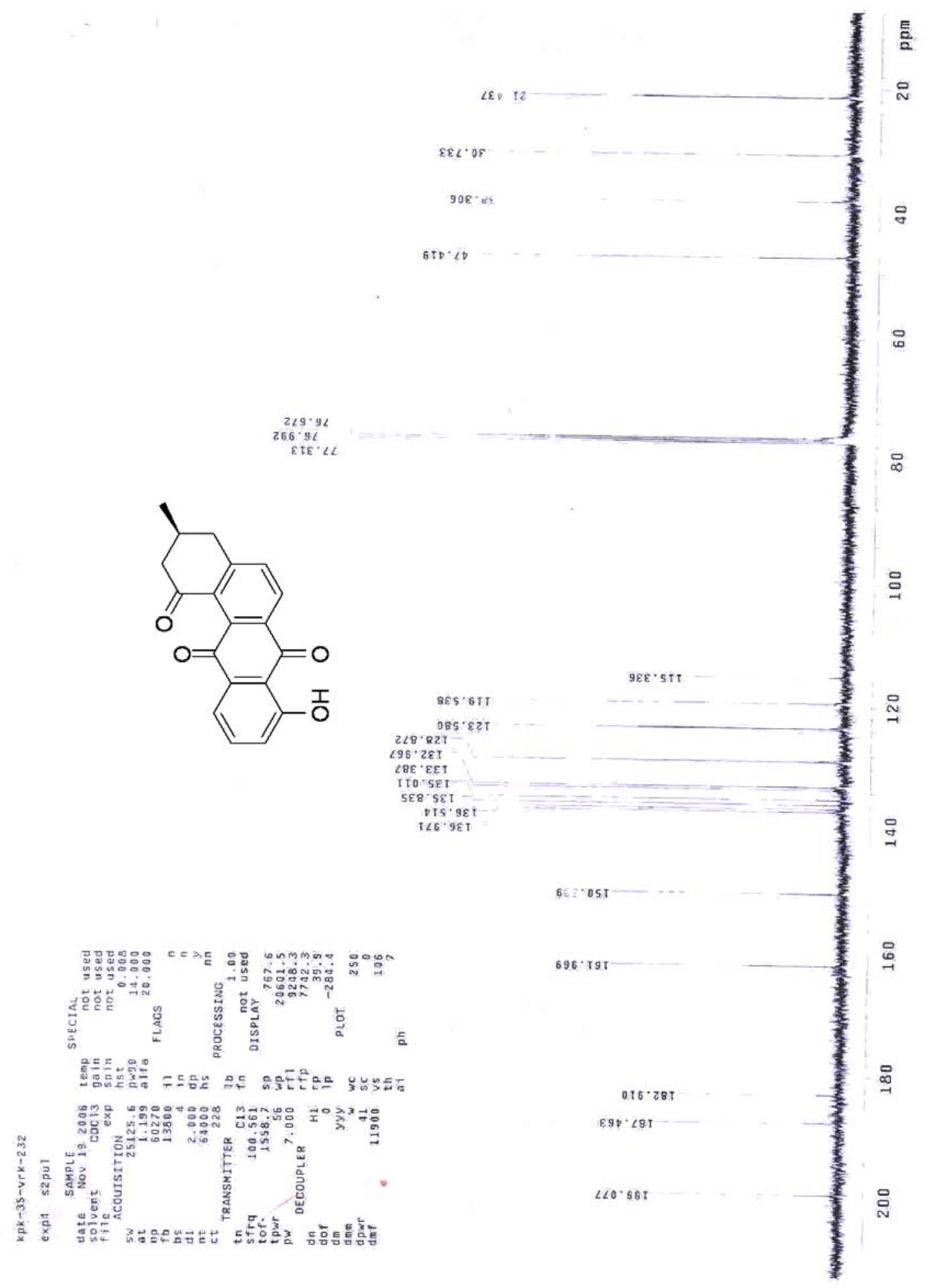




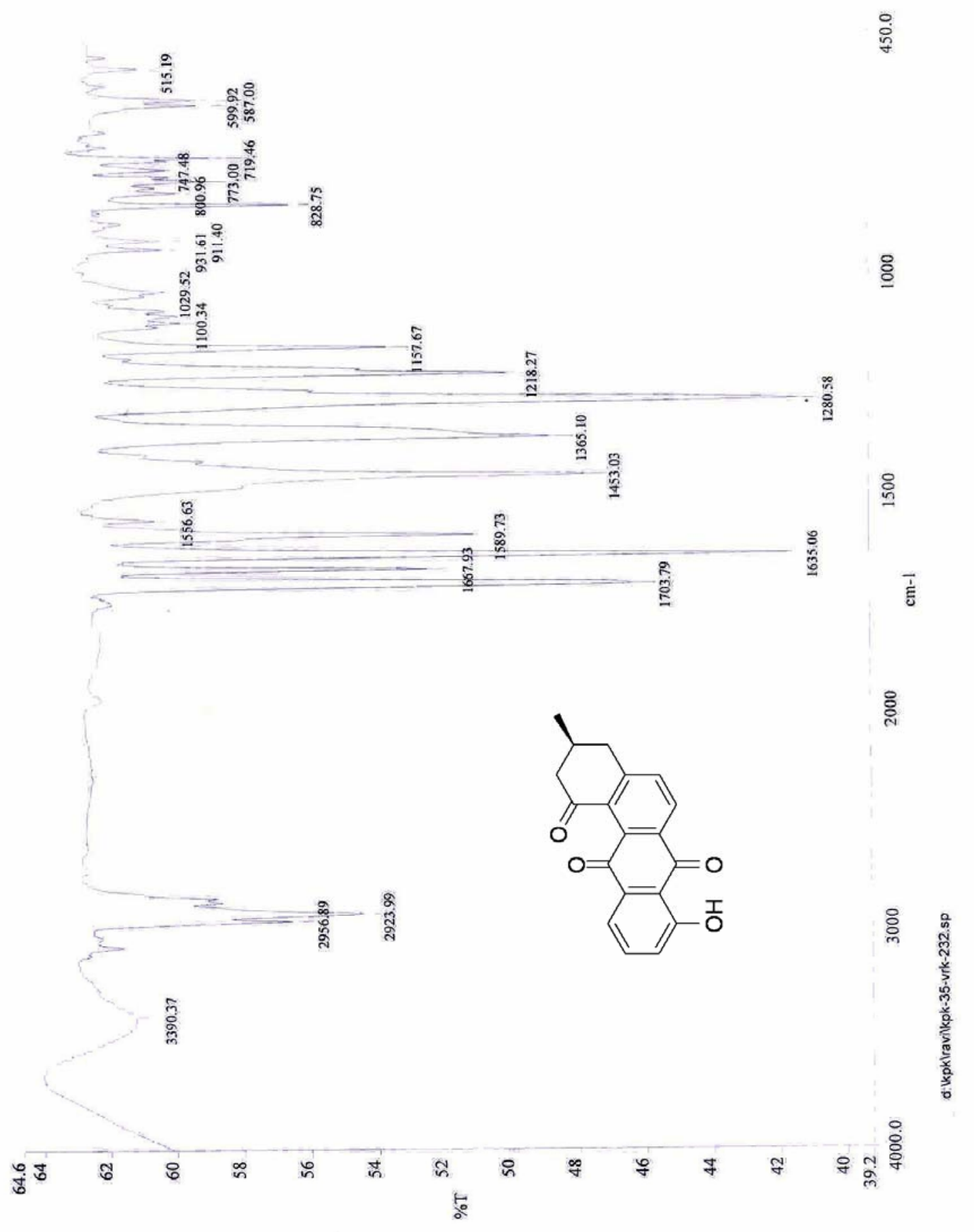


ำ
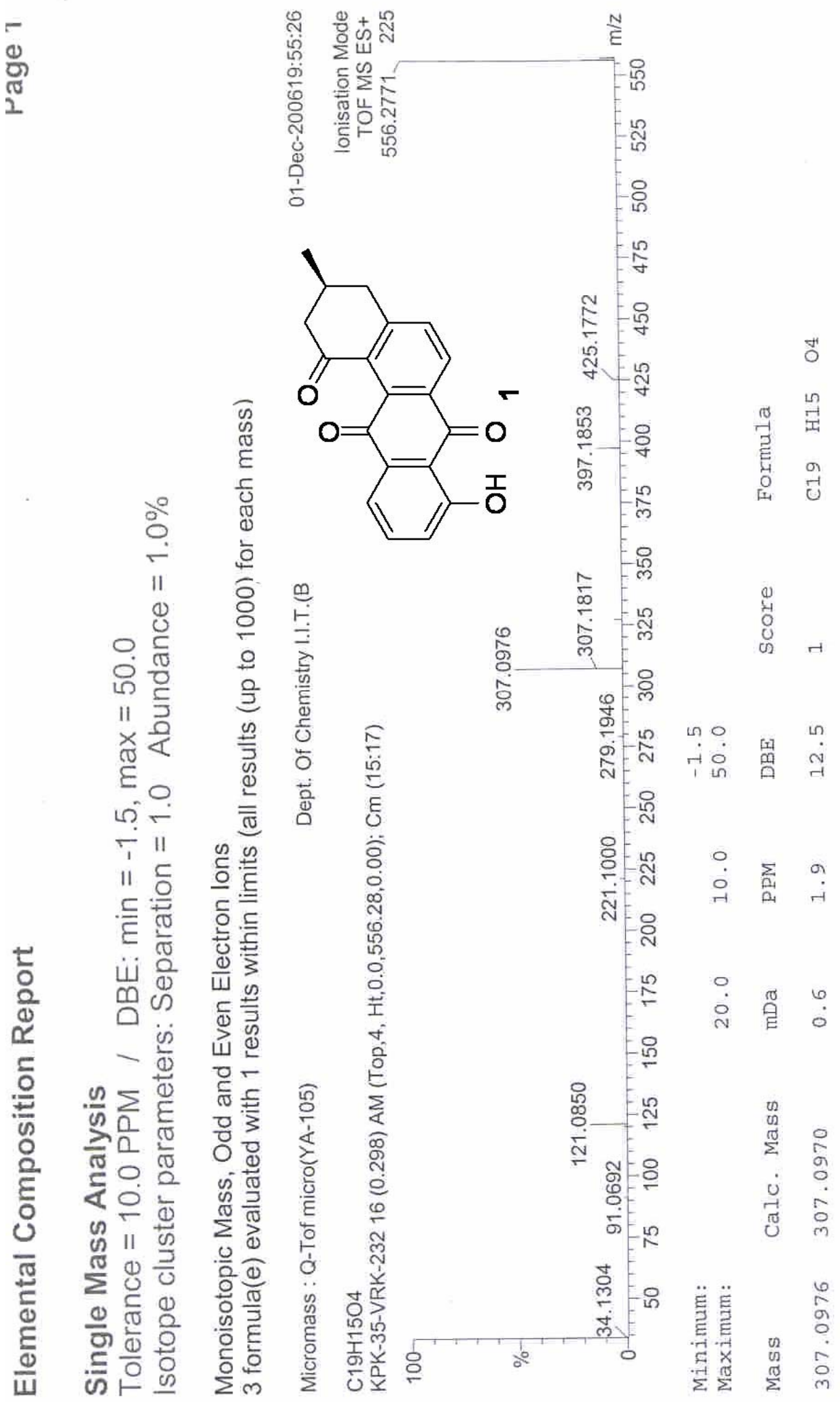

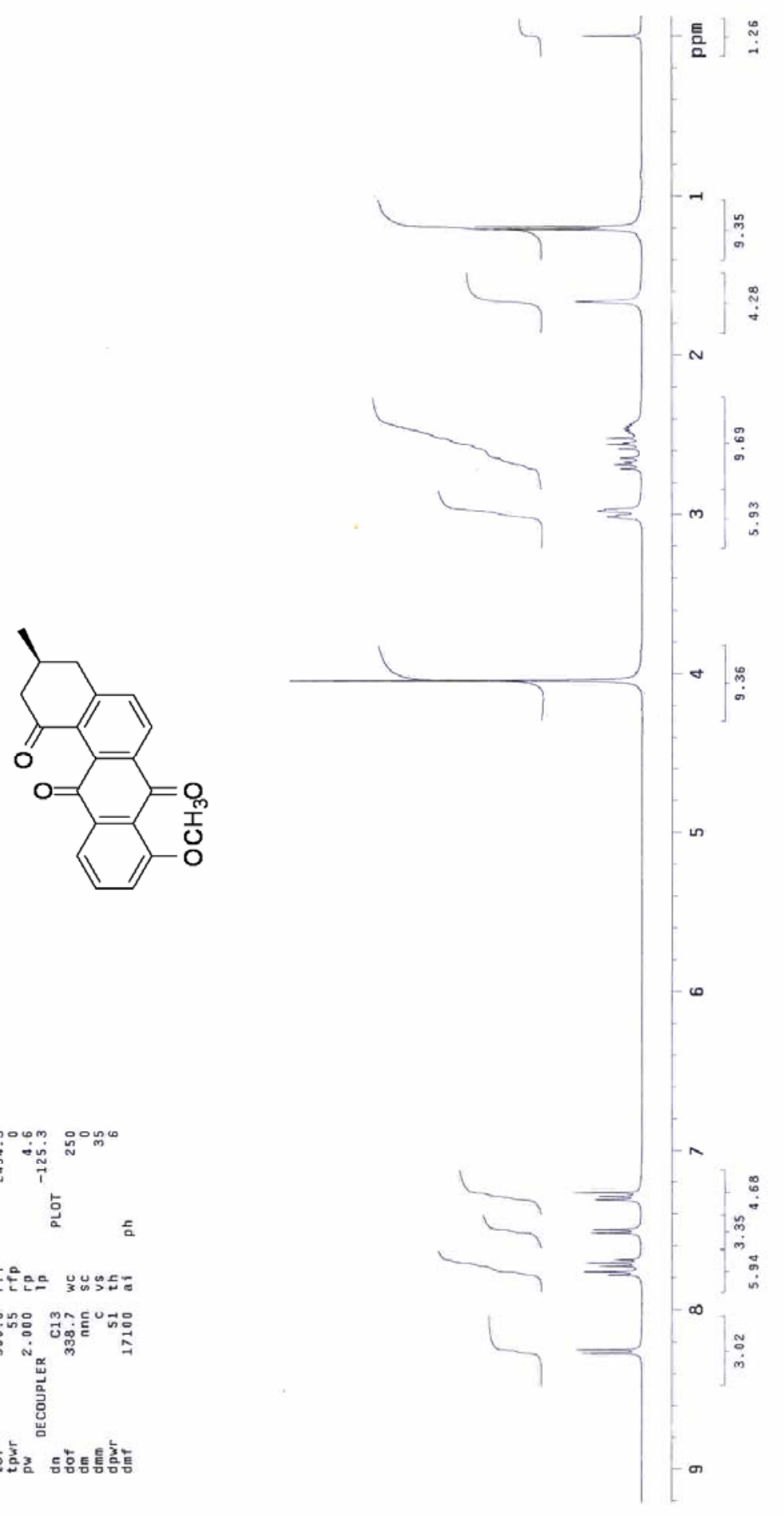

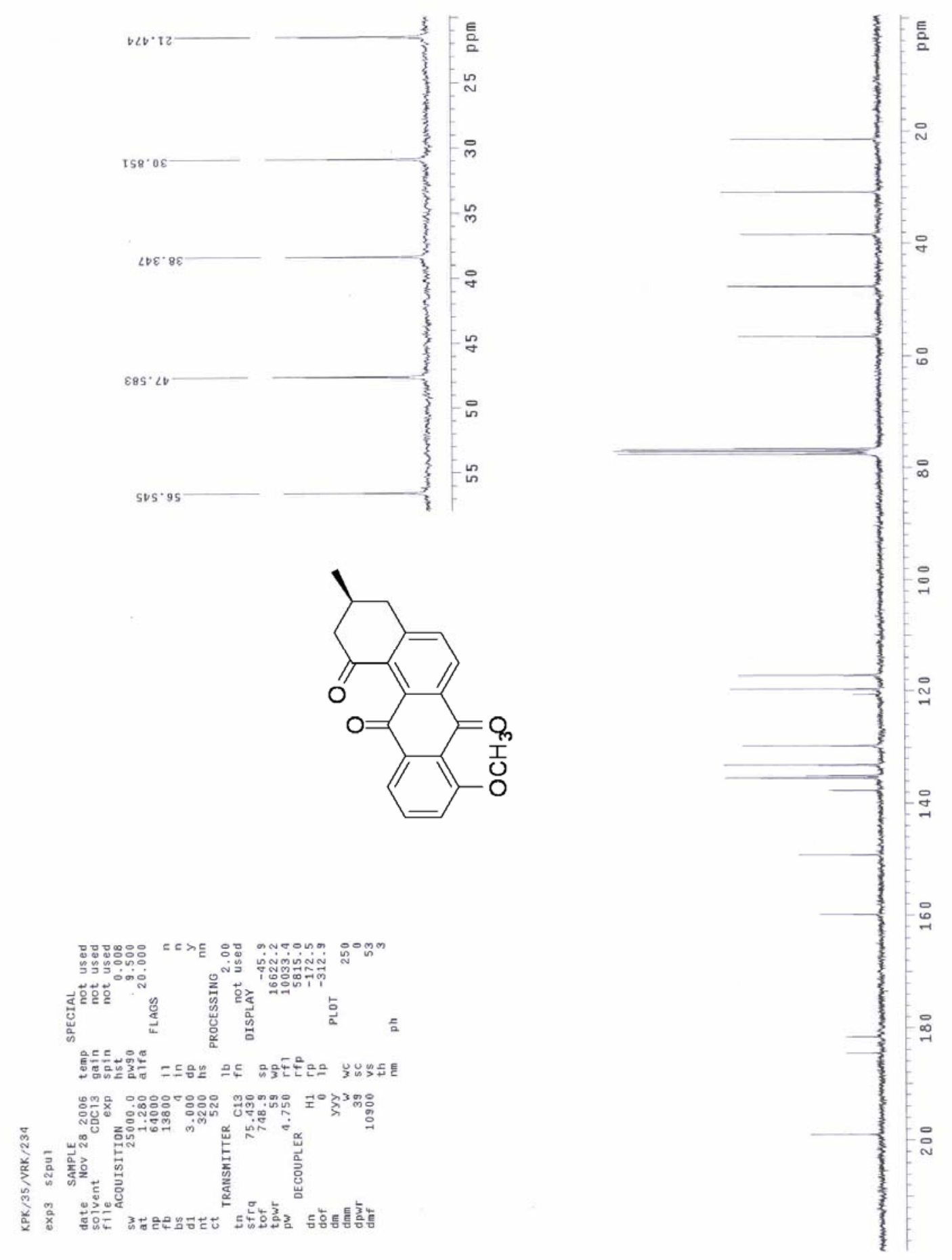


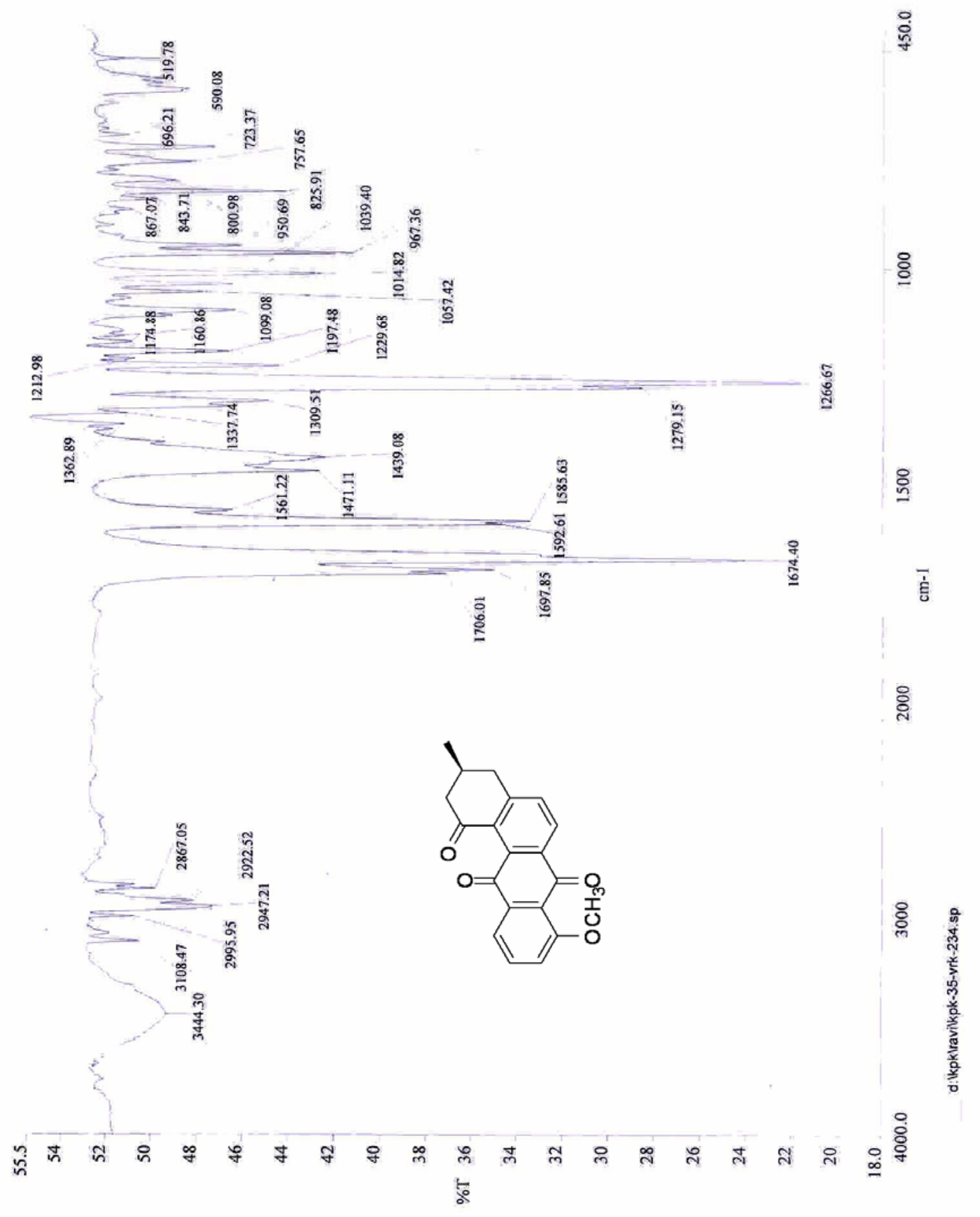




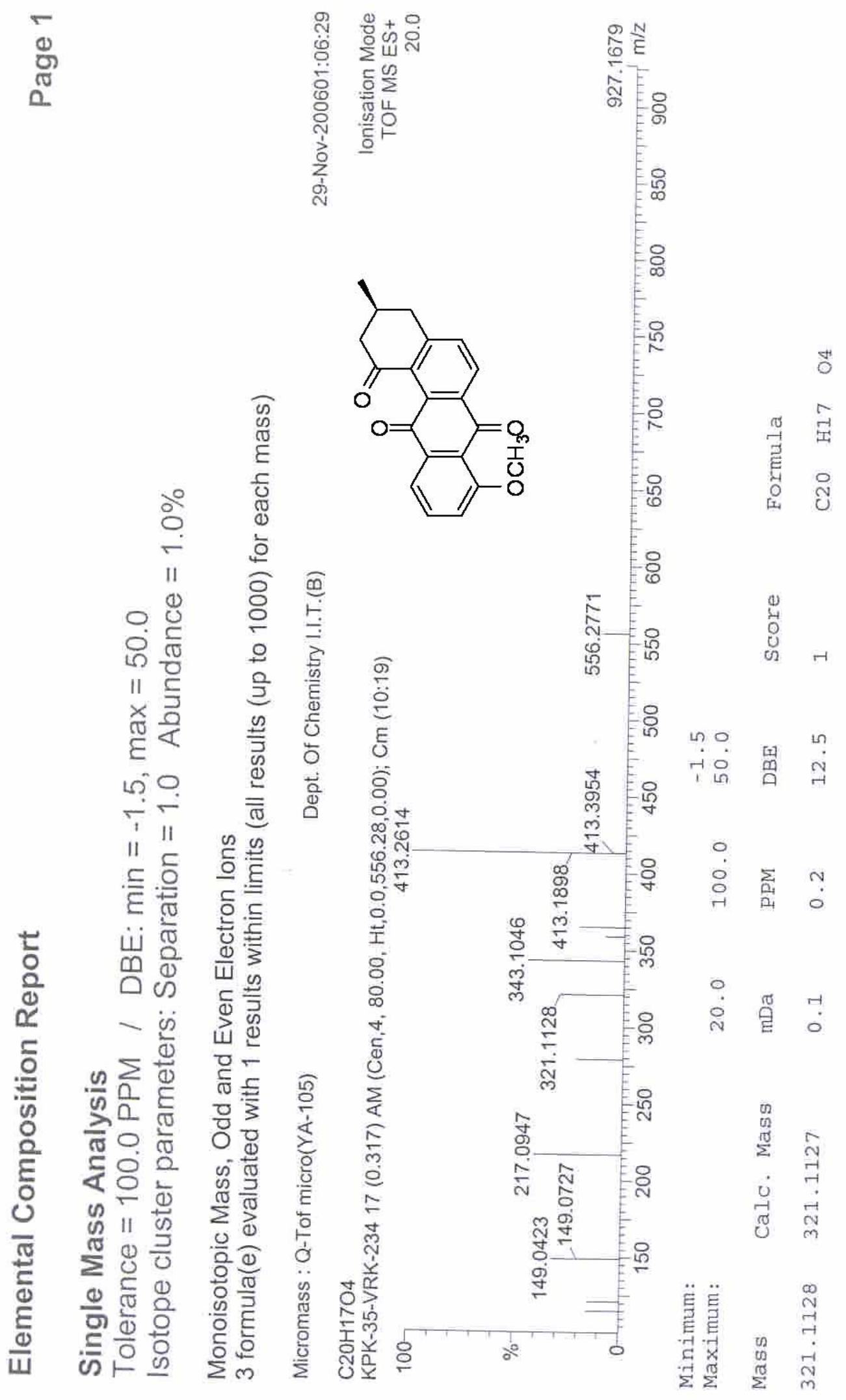




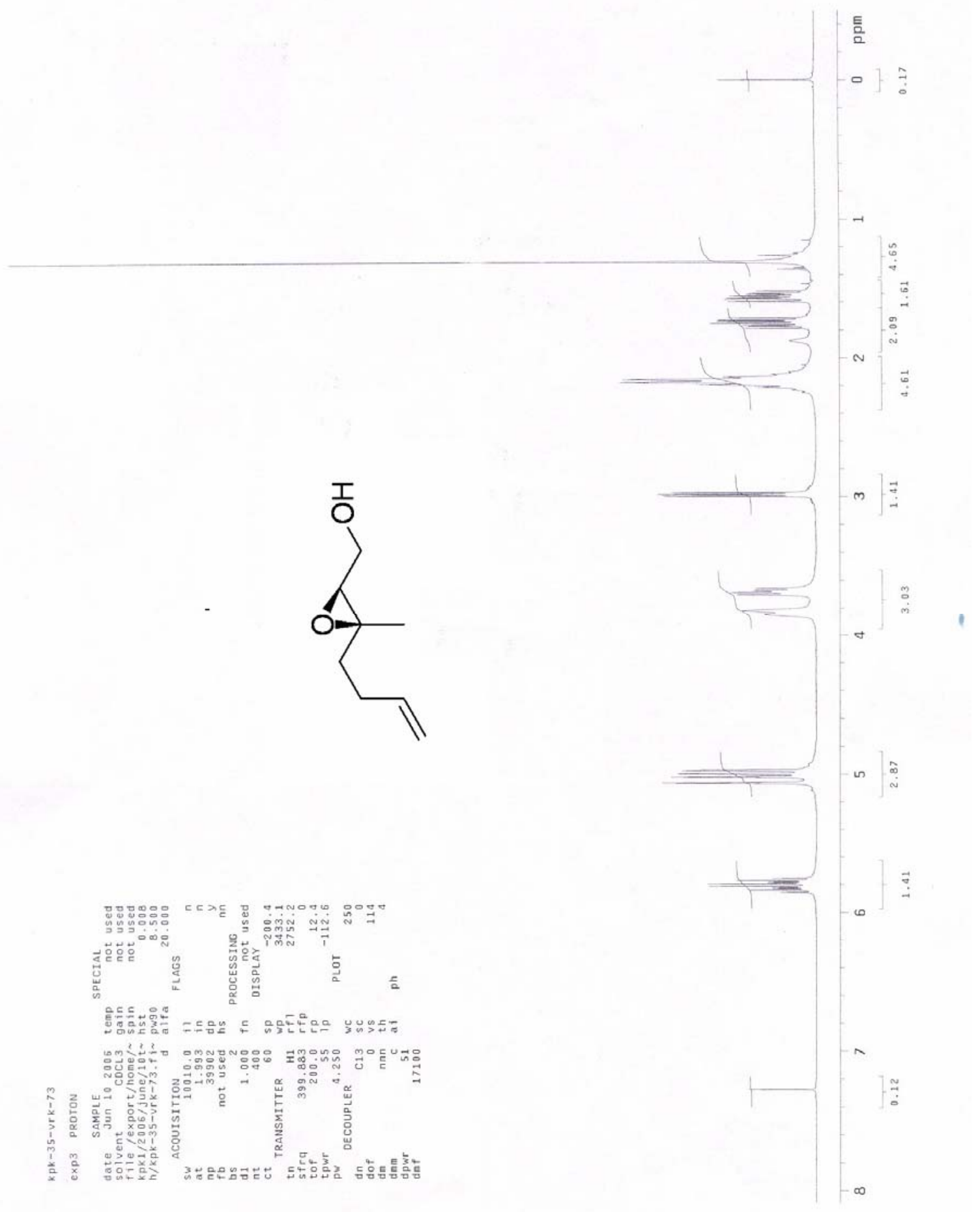




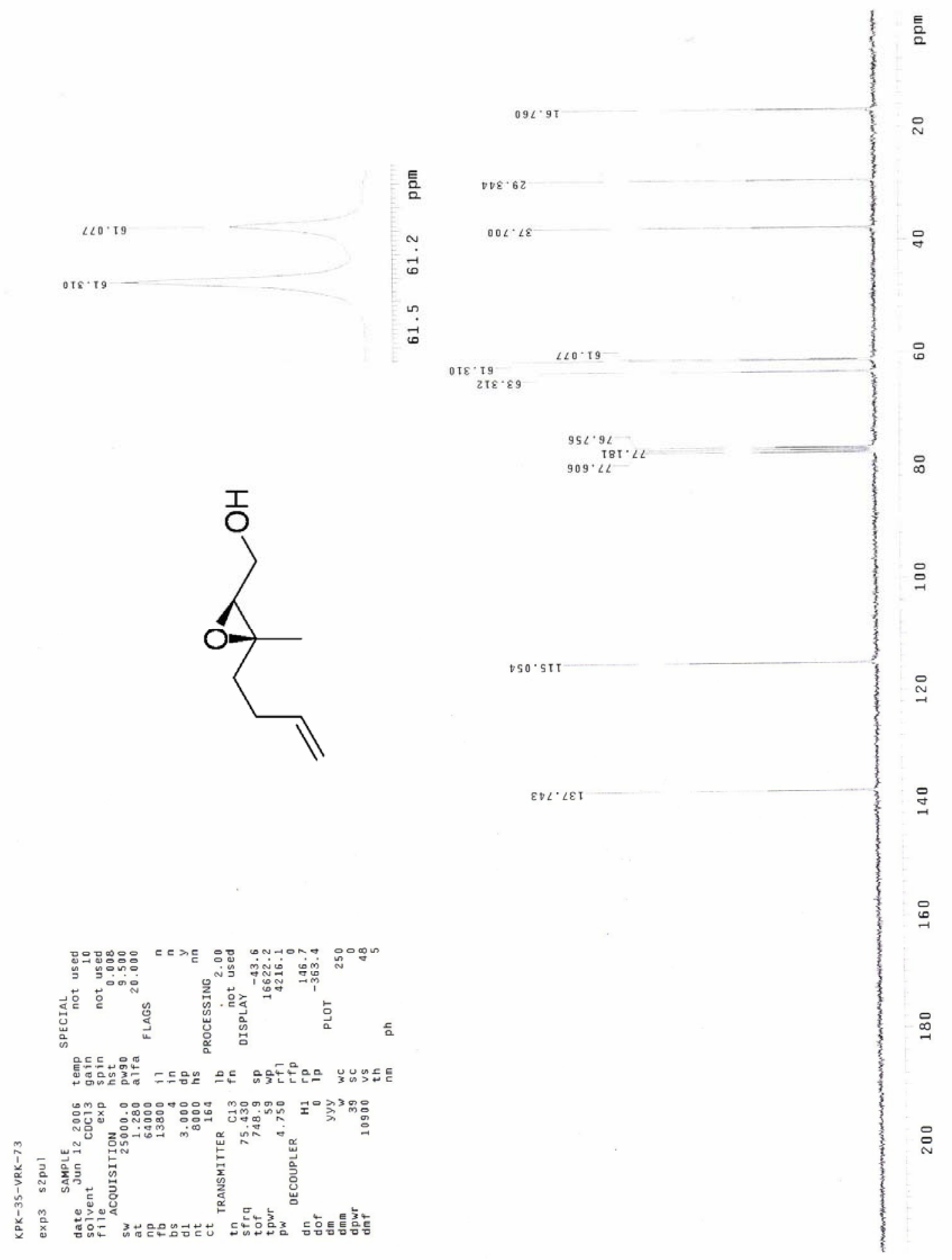




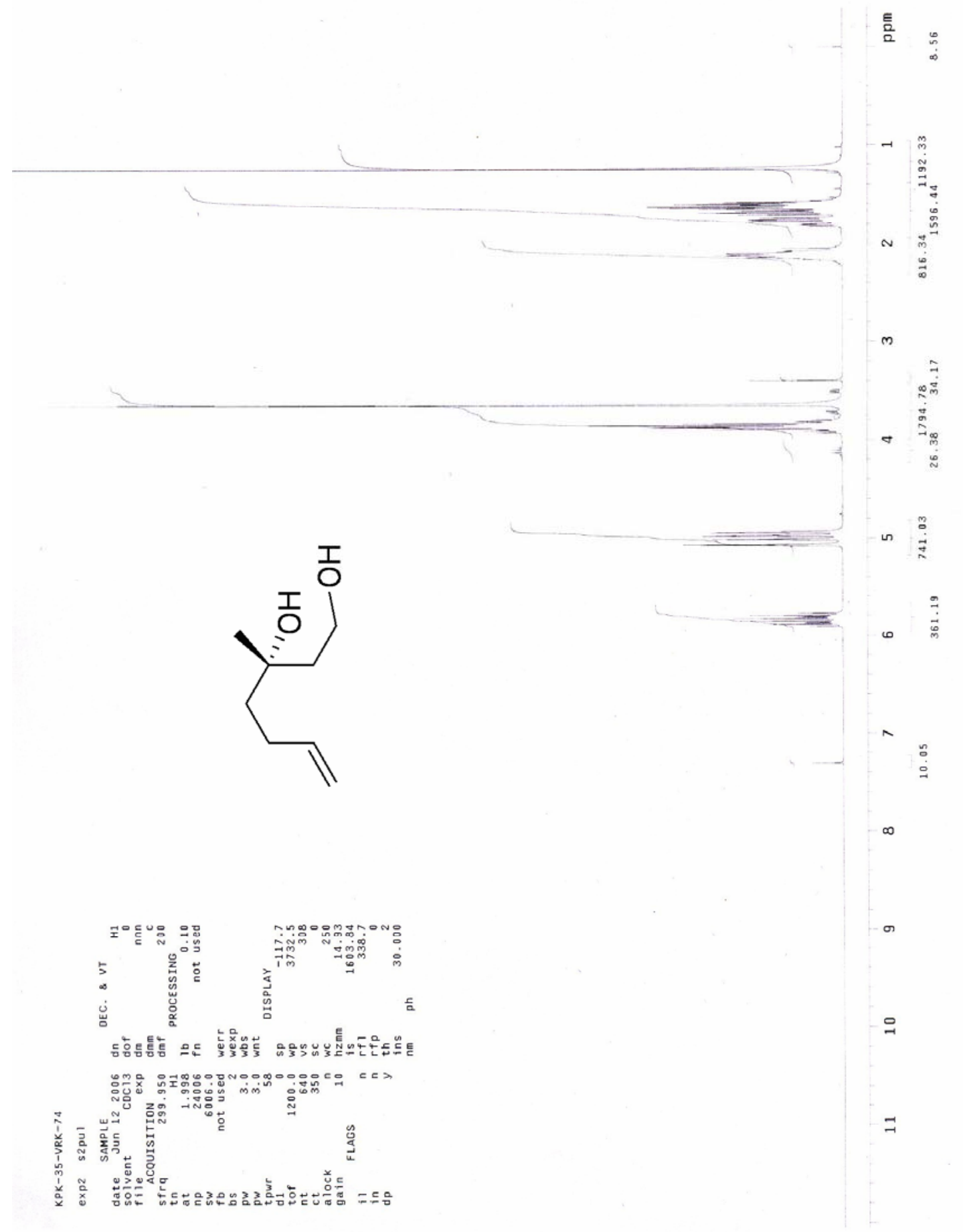




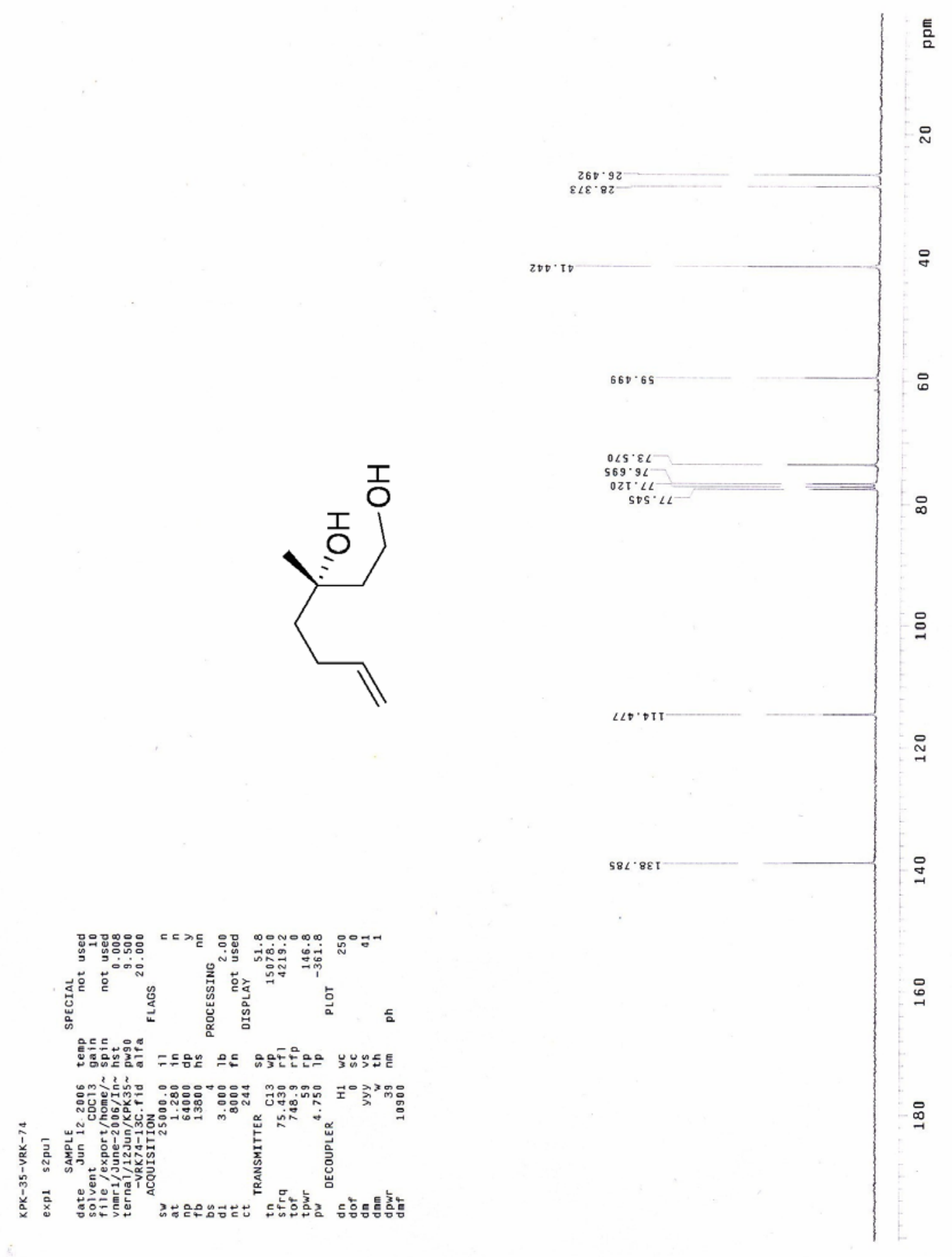




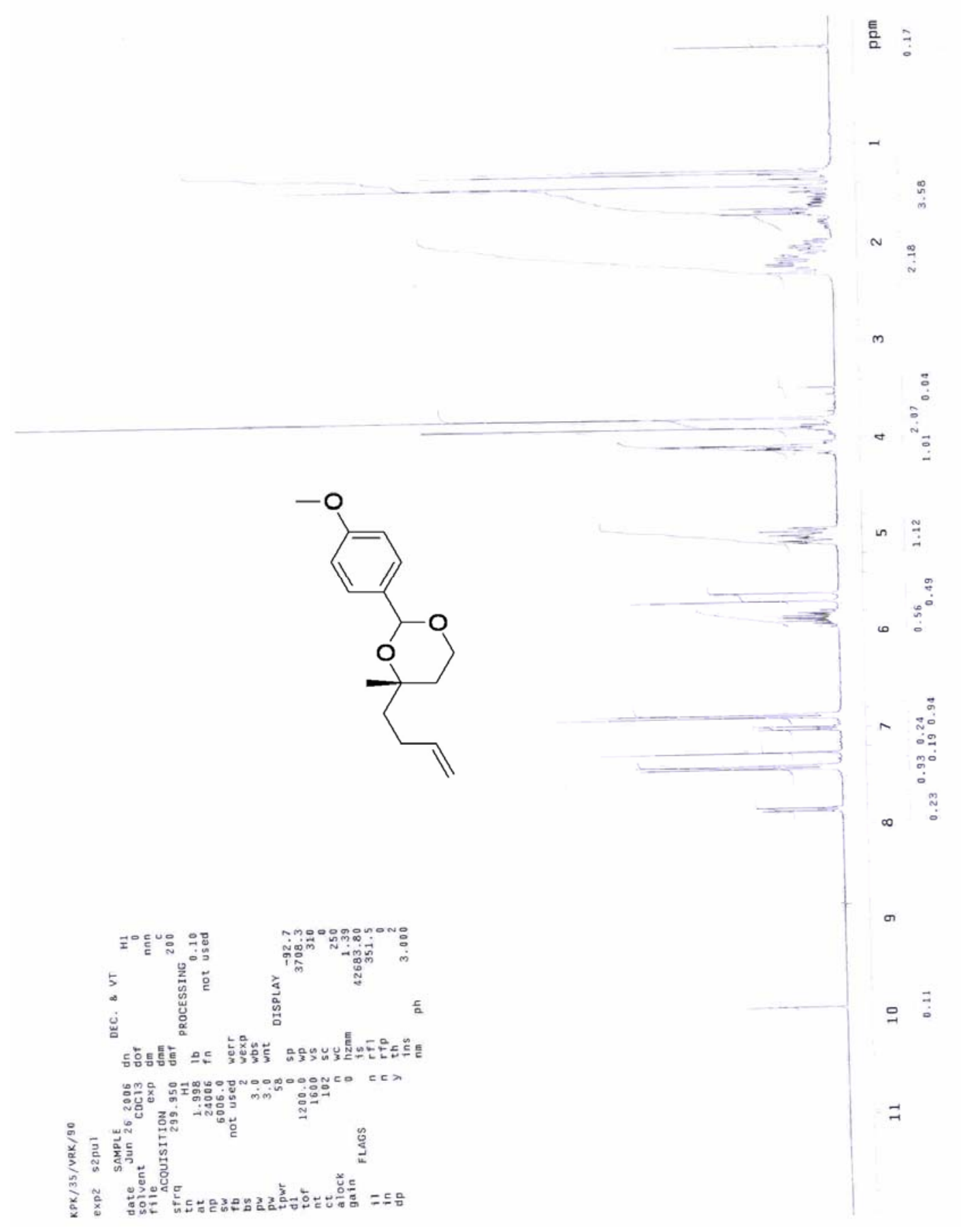




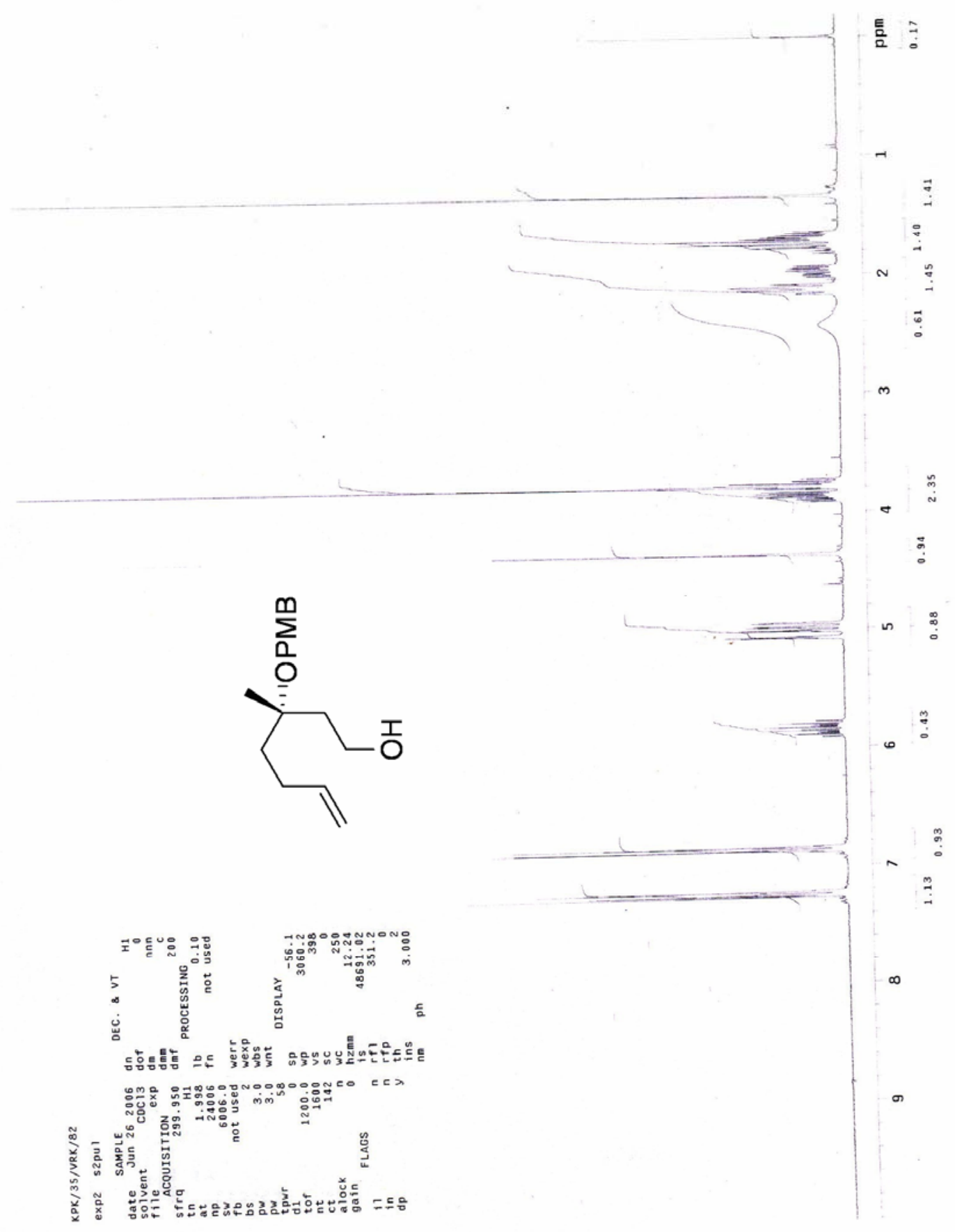




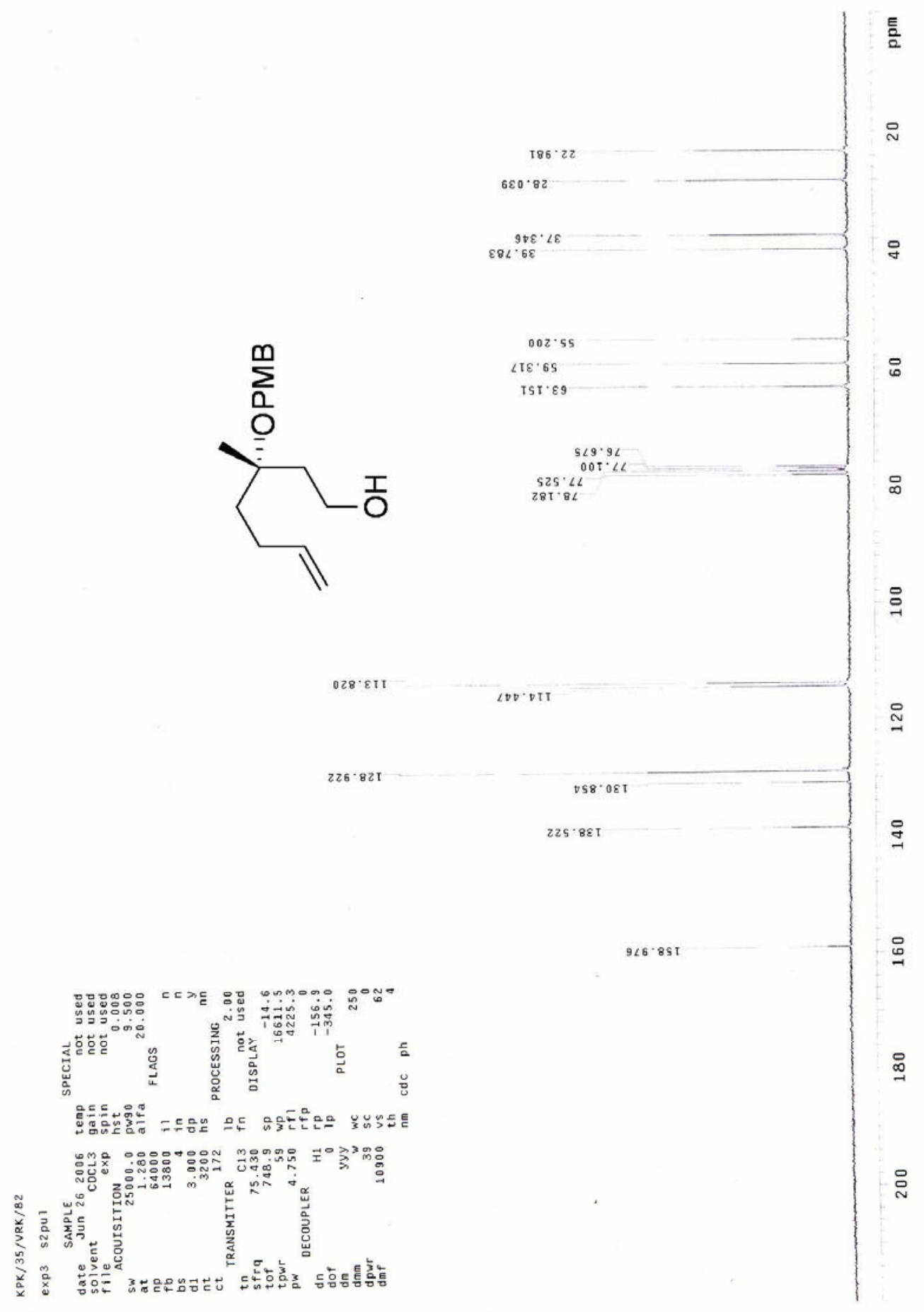




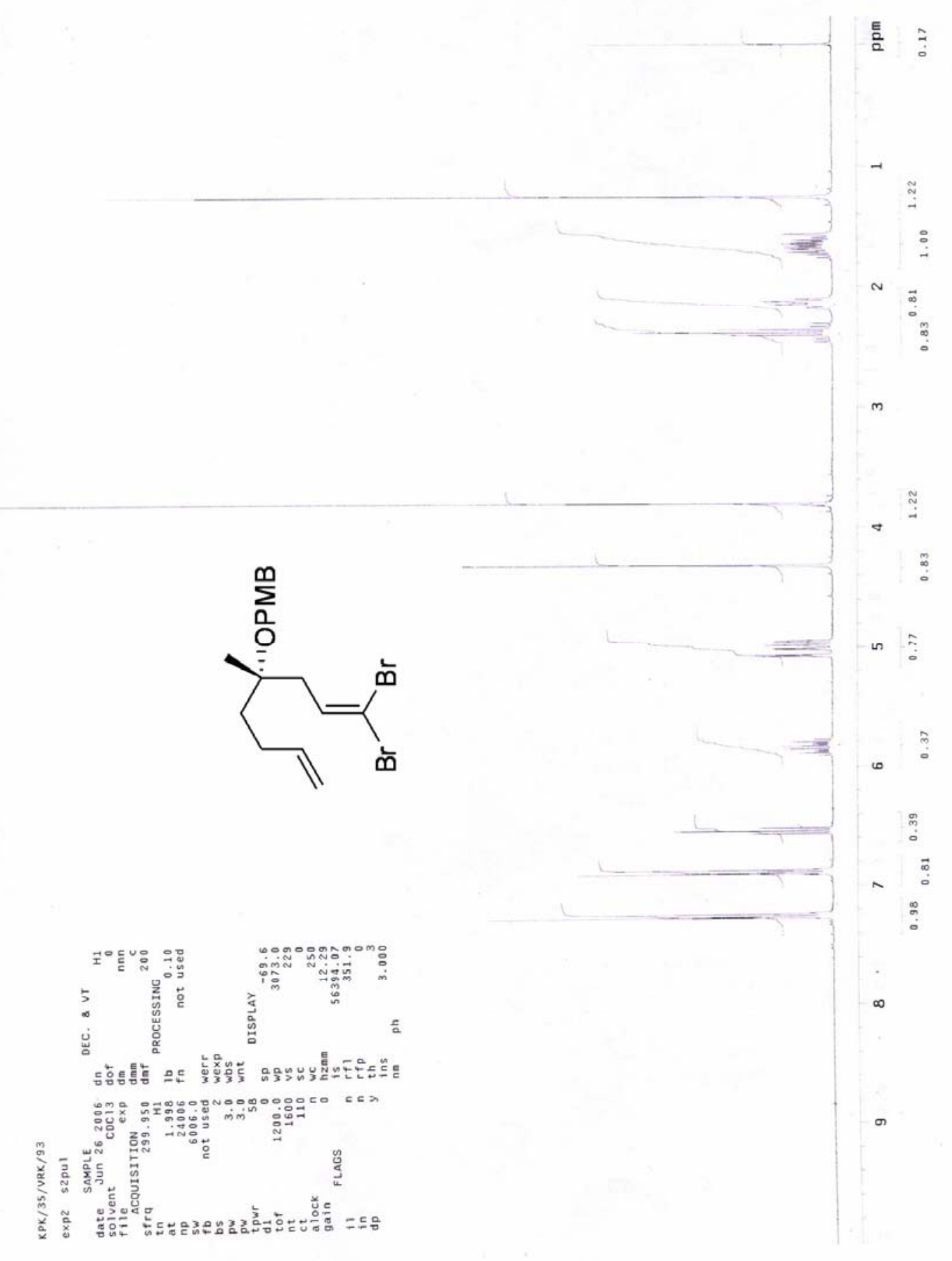




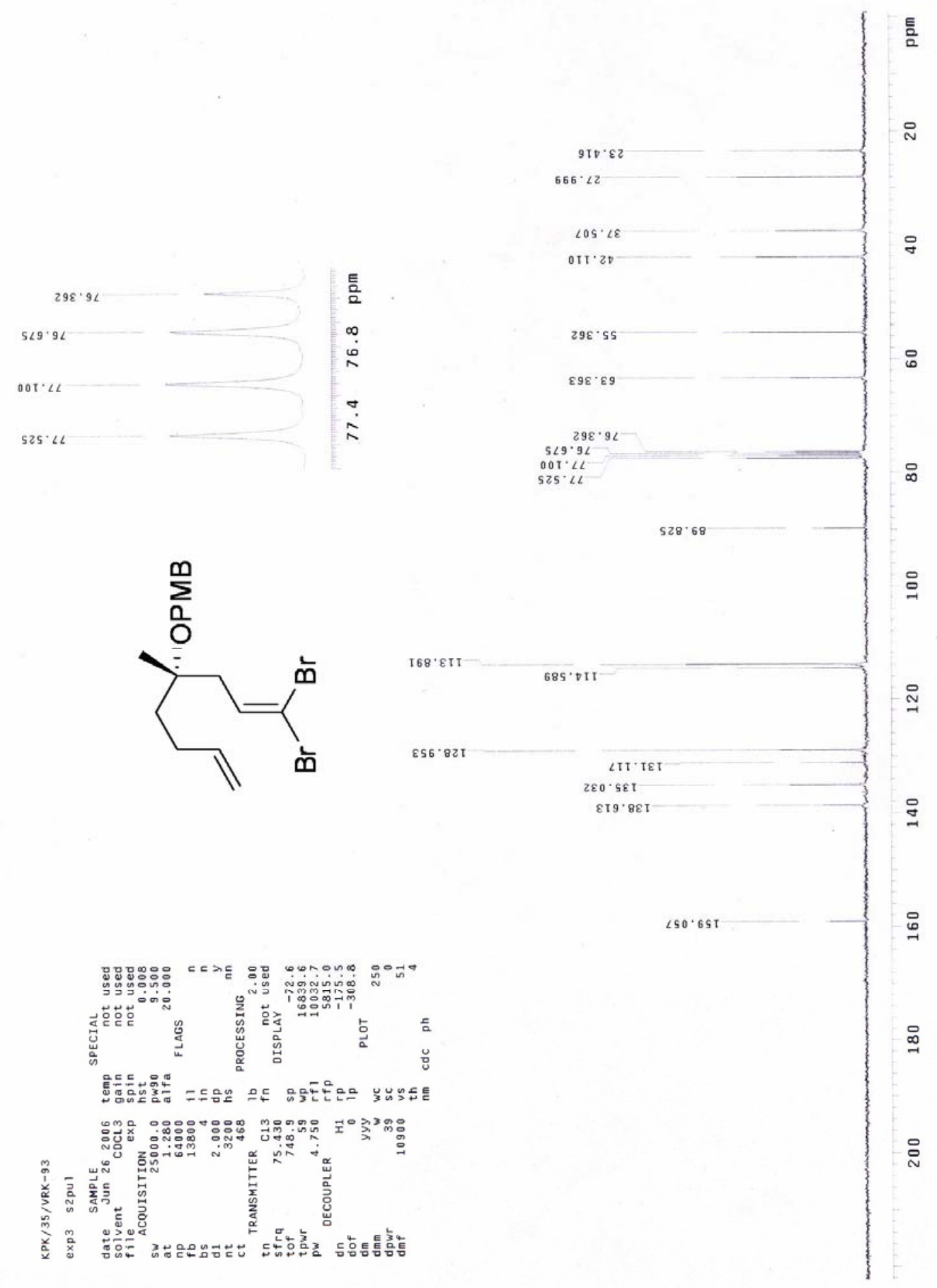




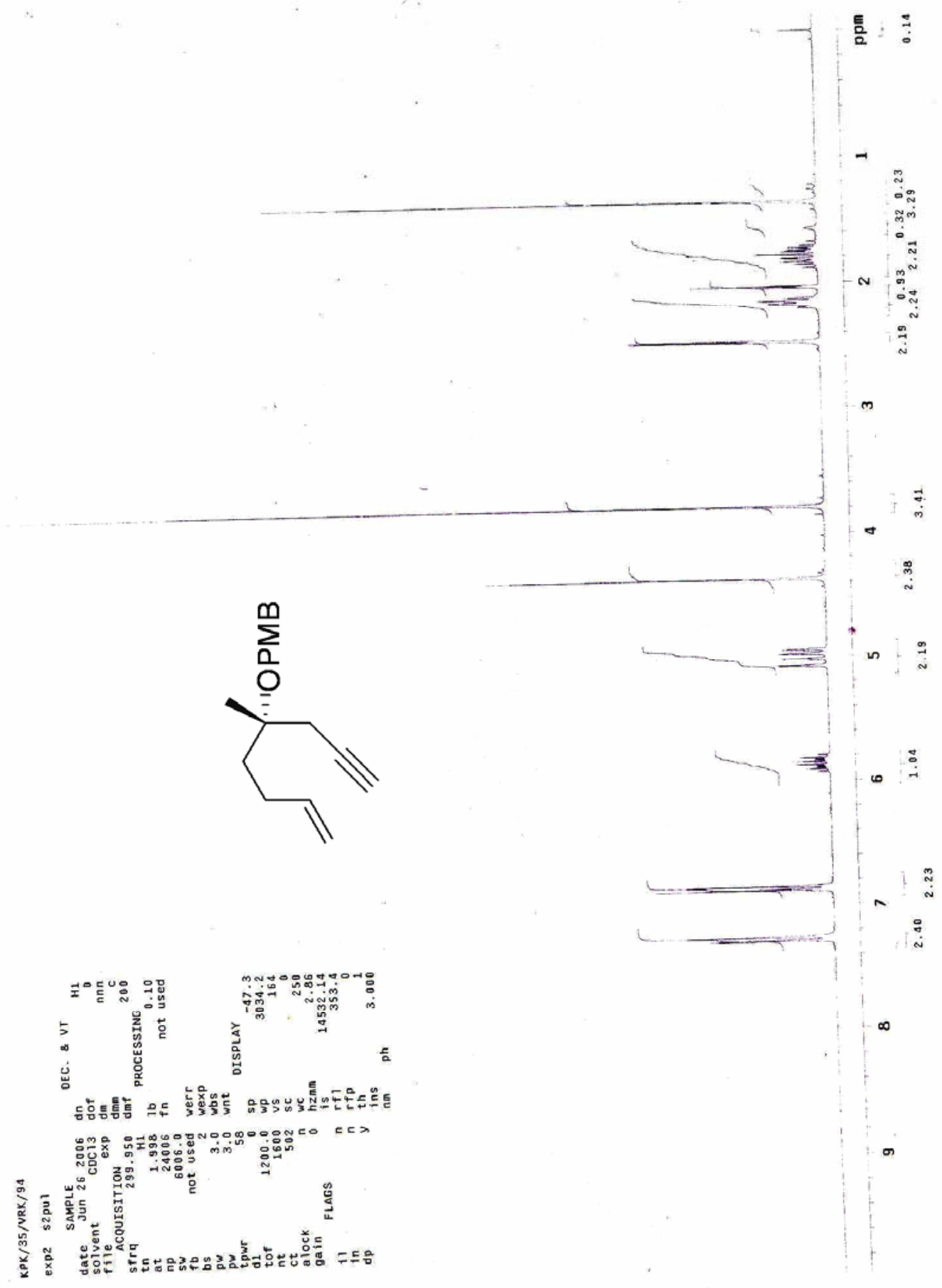




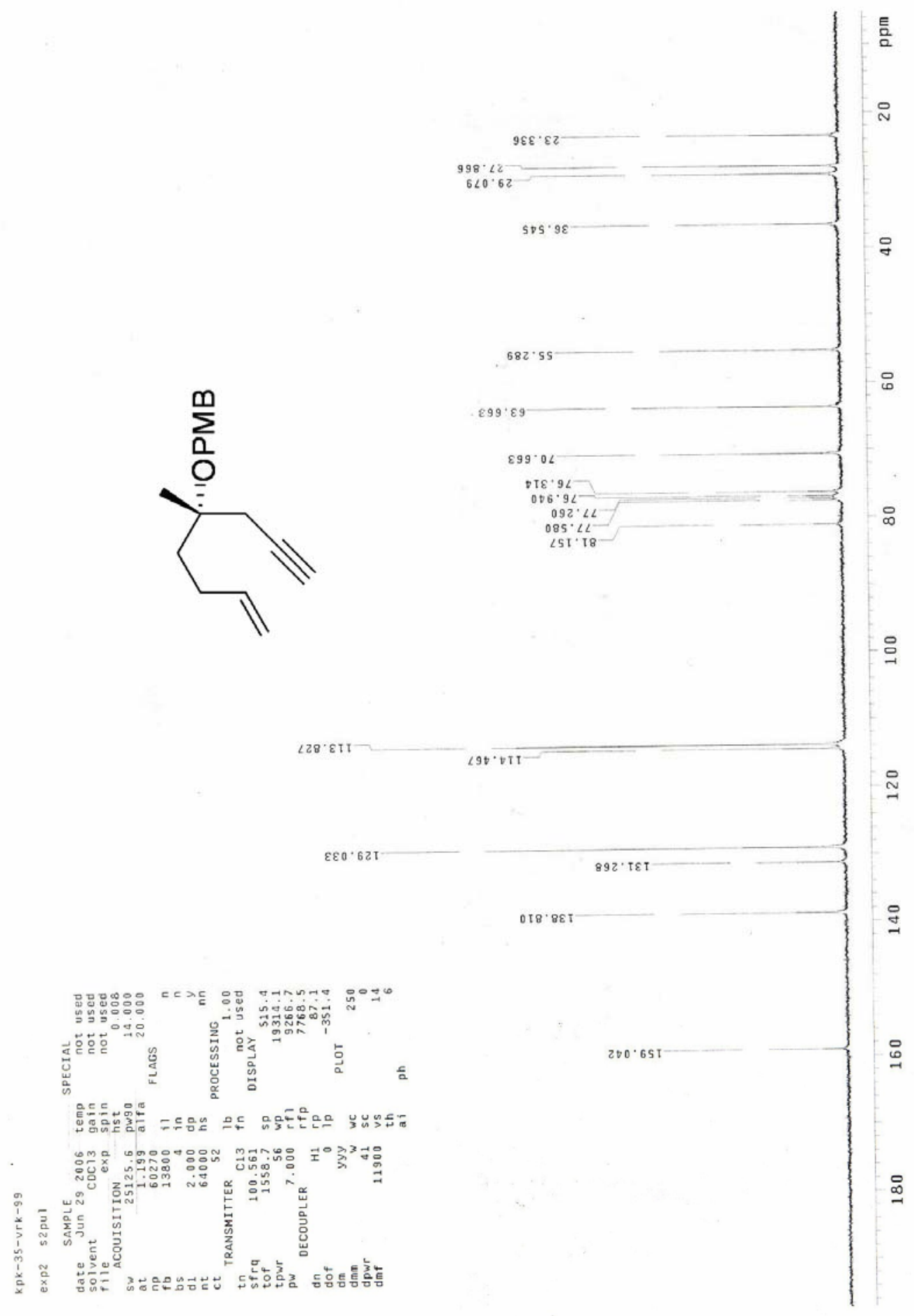




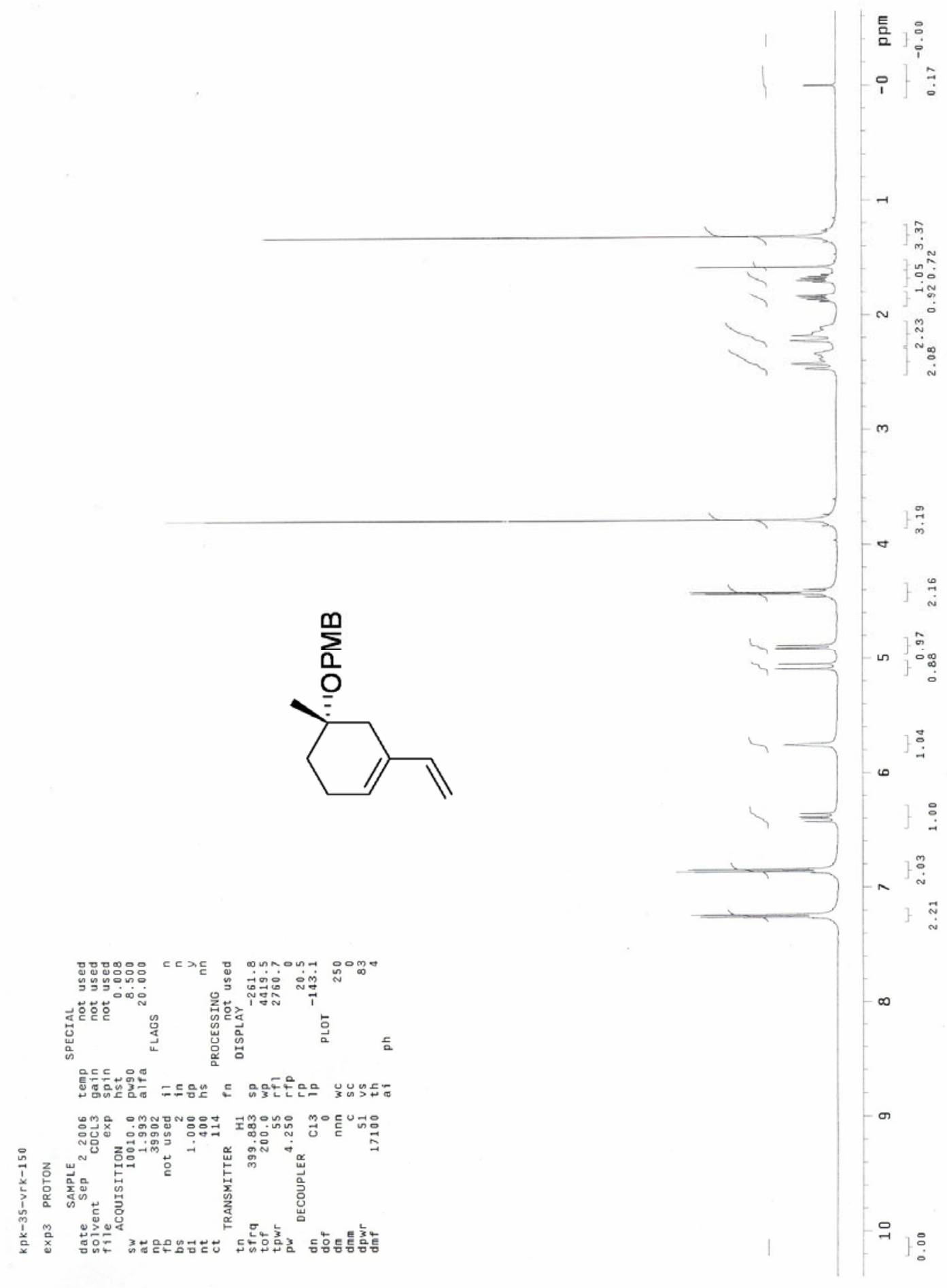




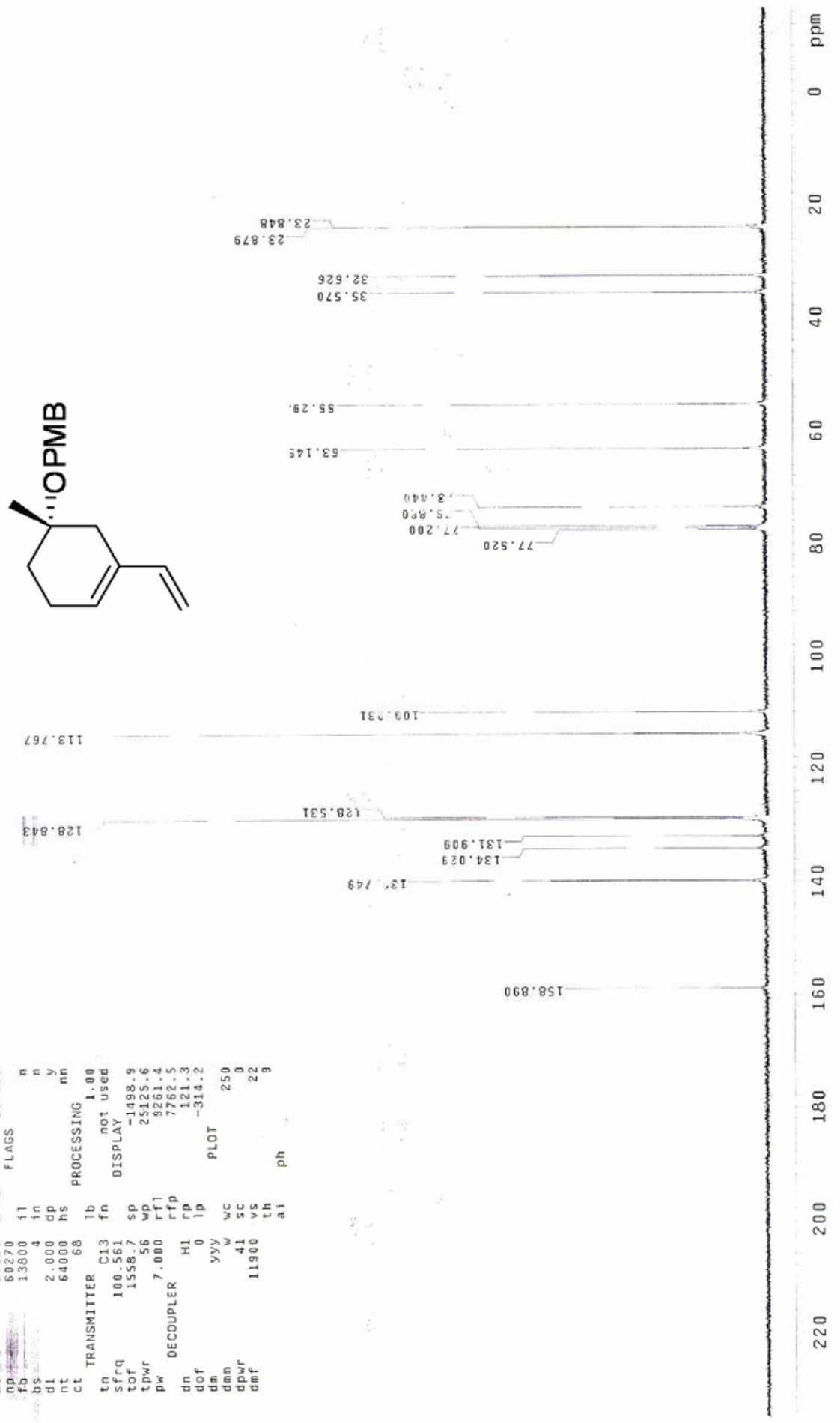




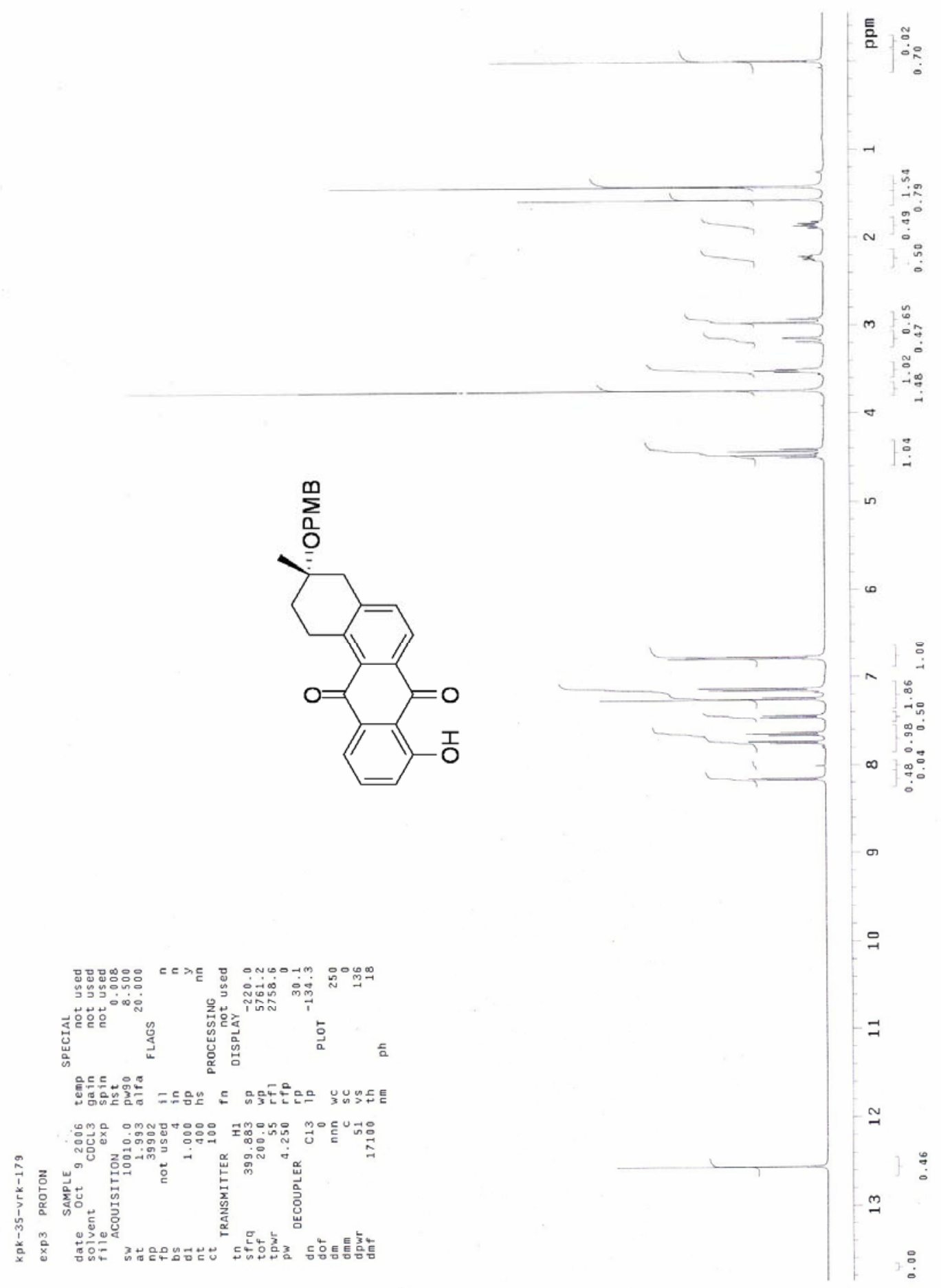




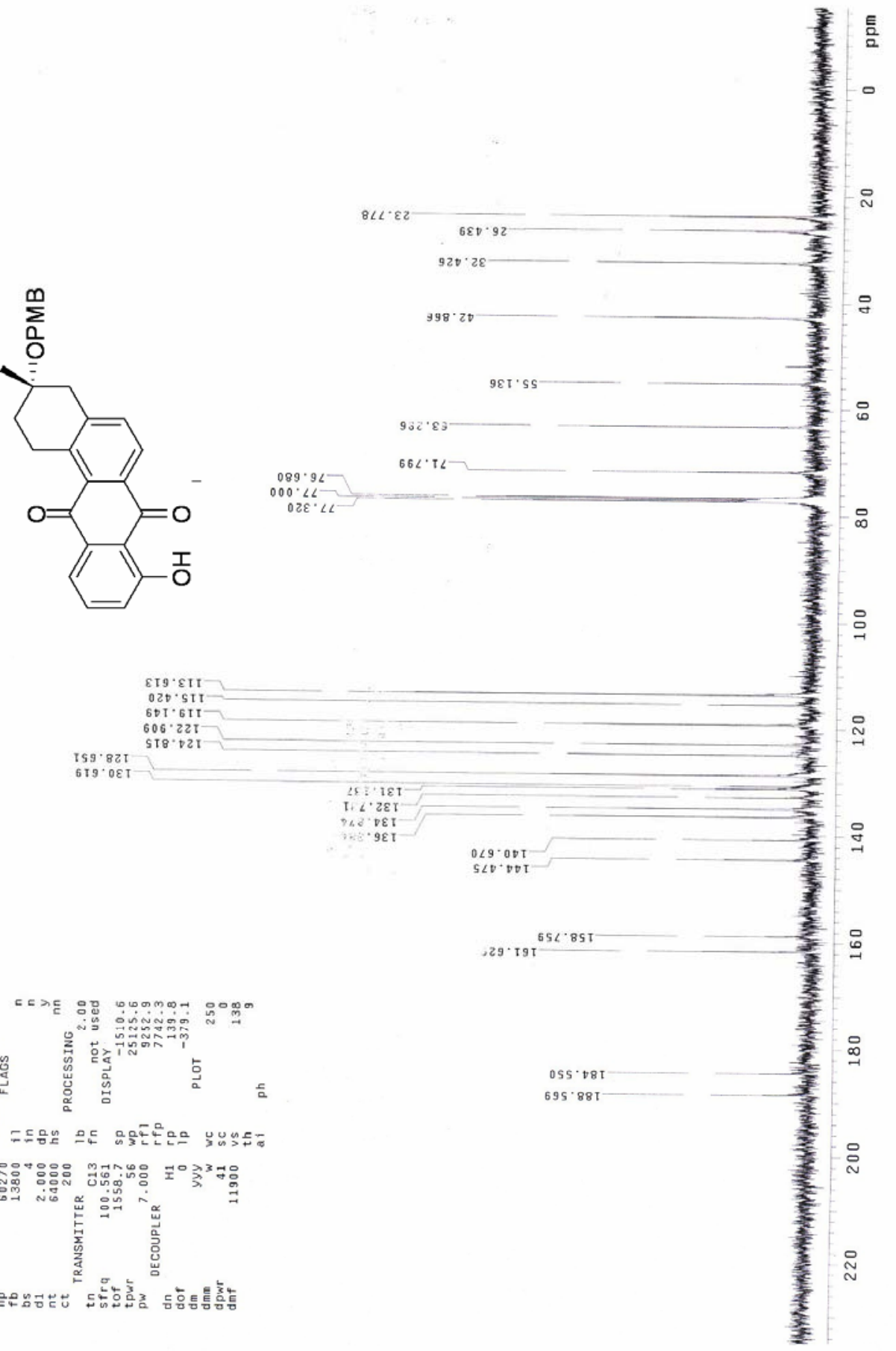




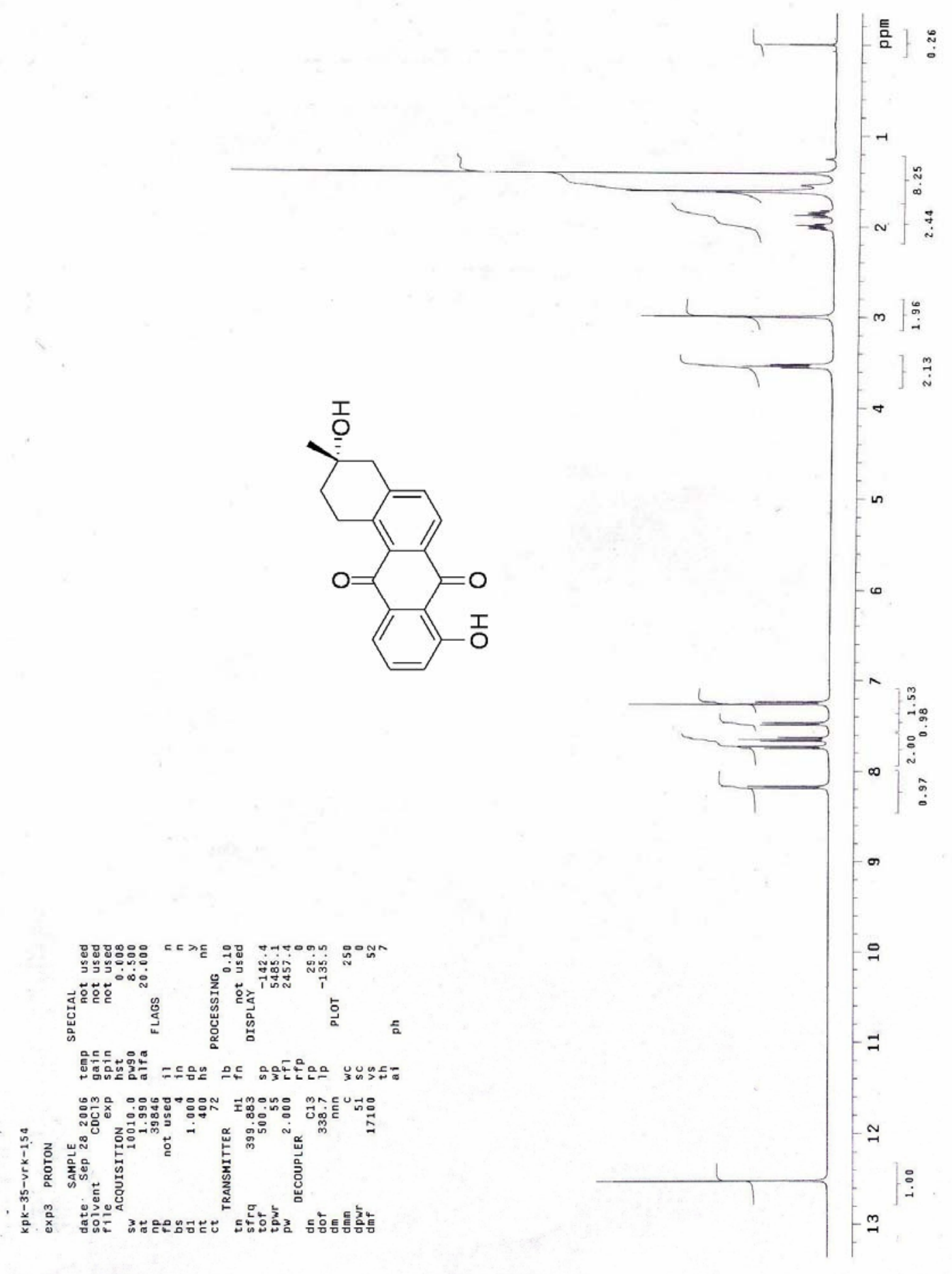




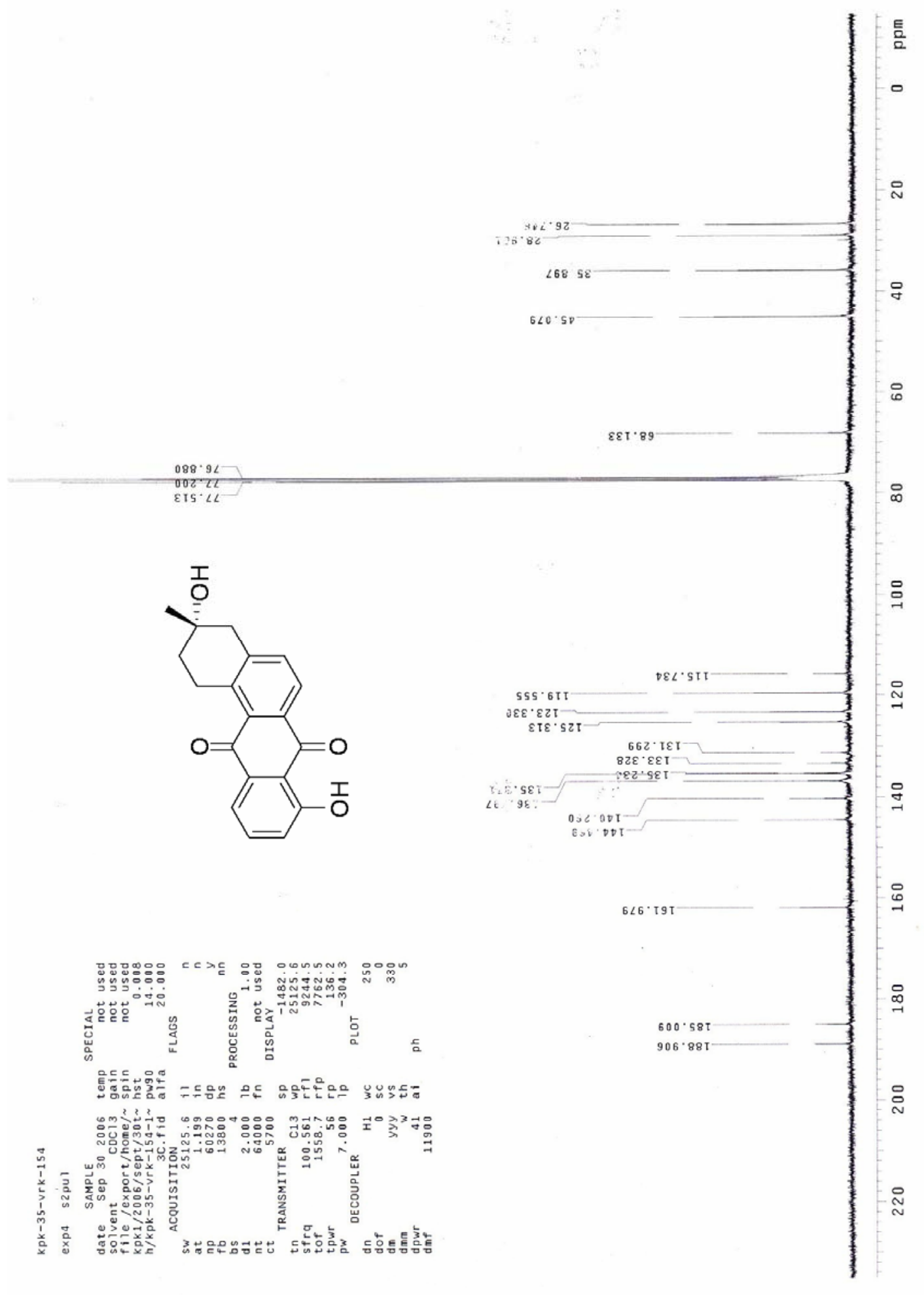




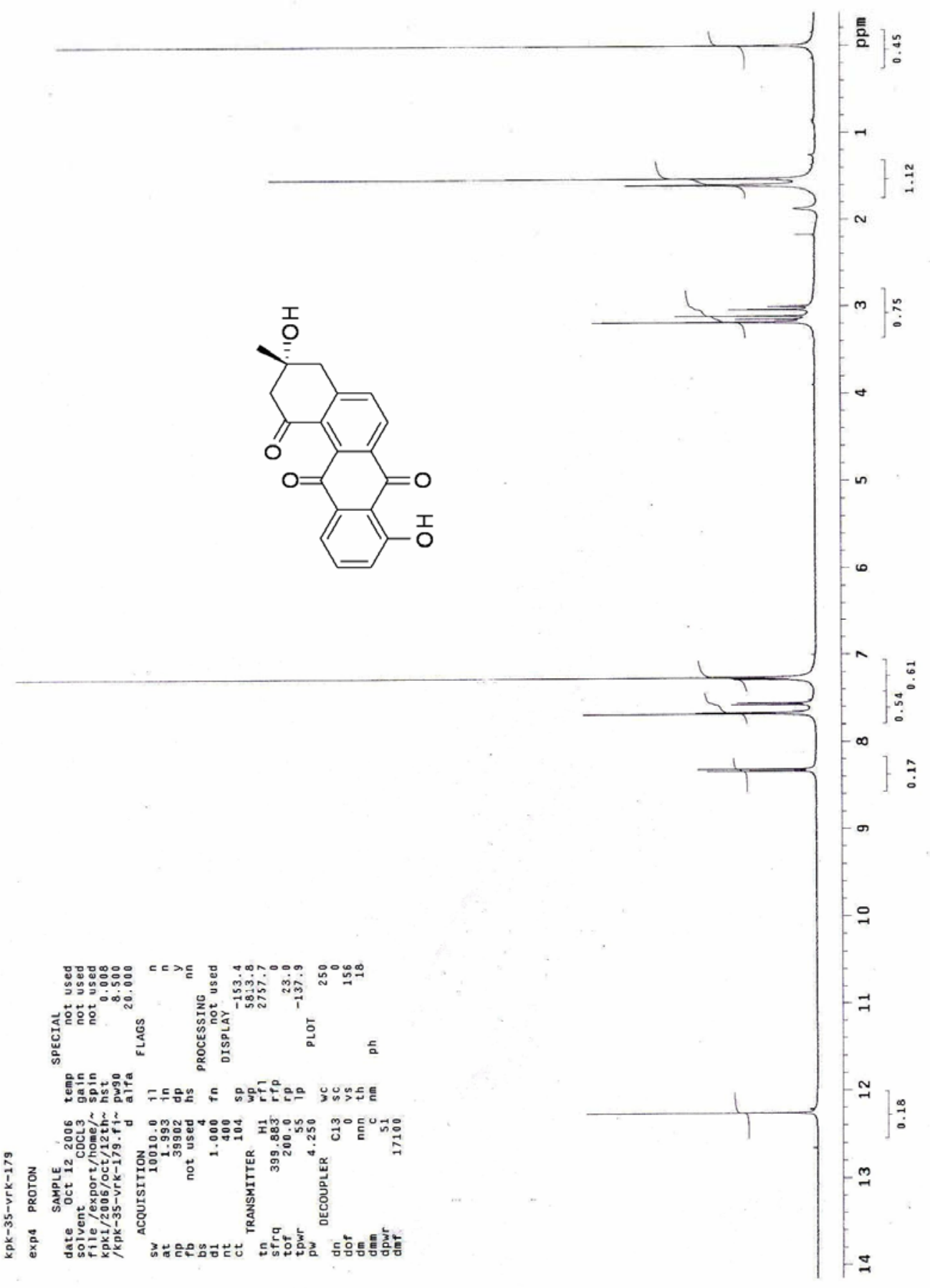




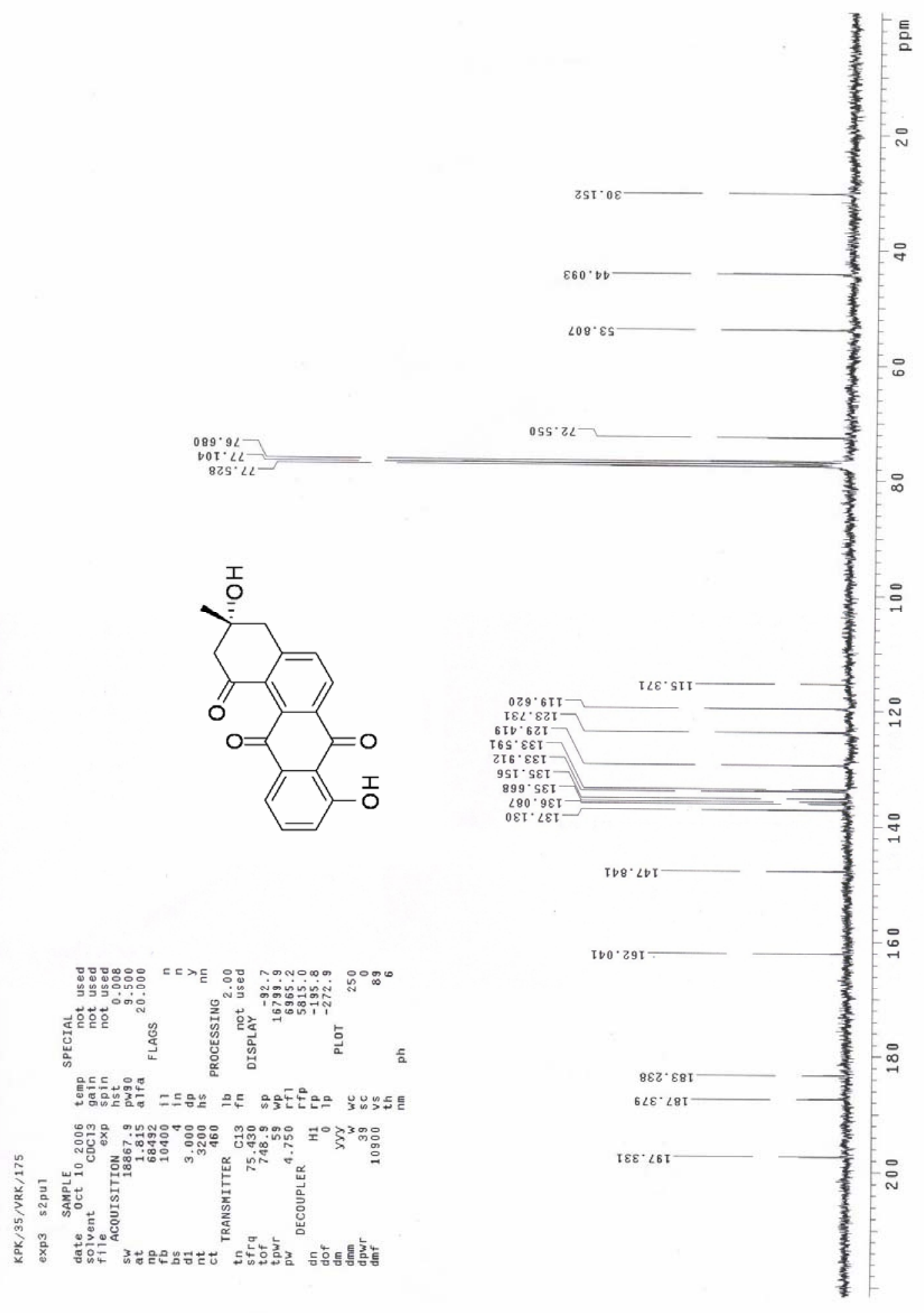




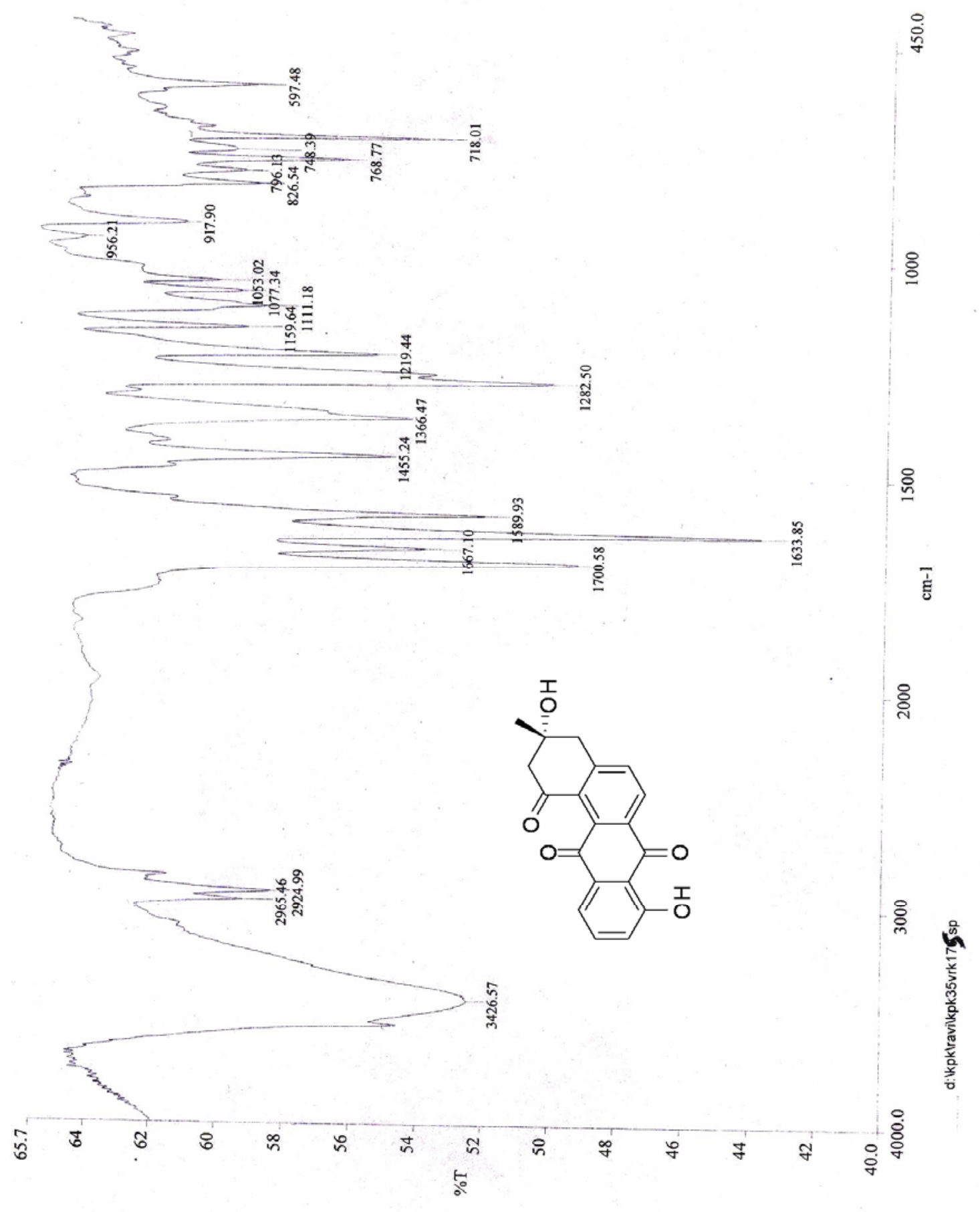



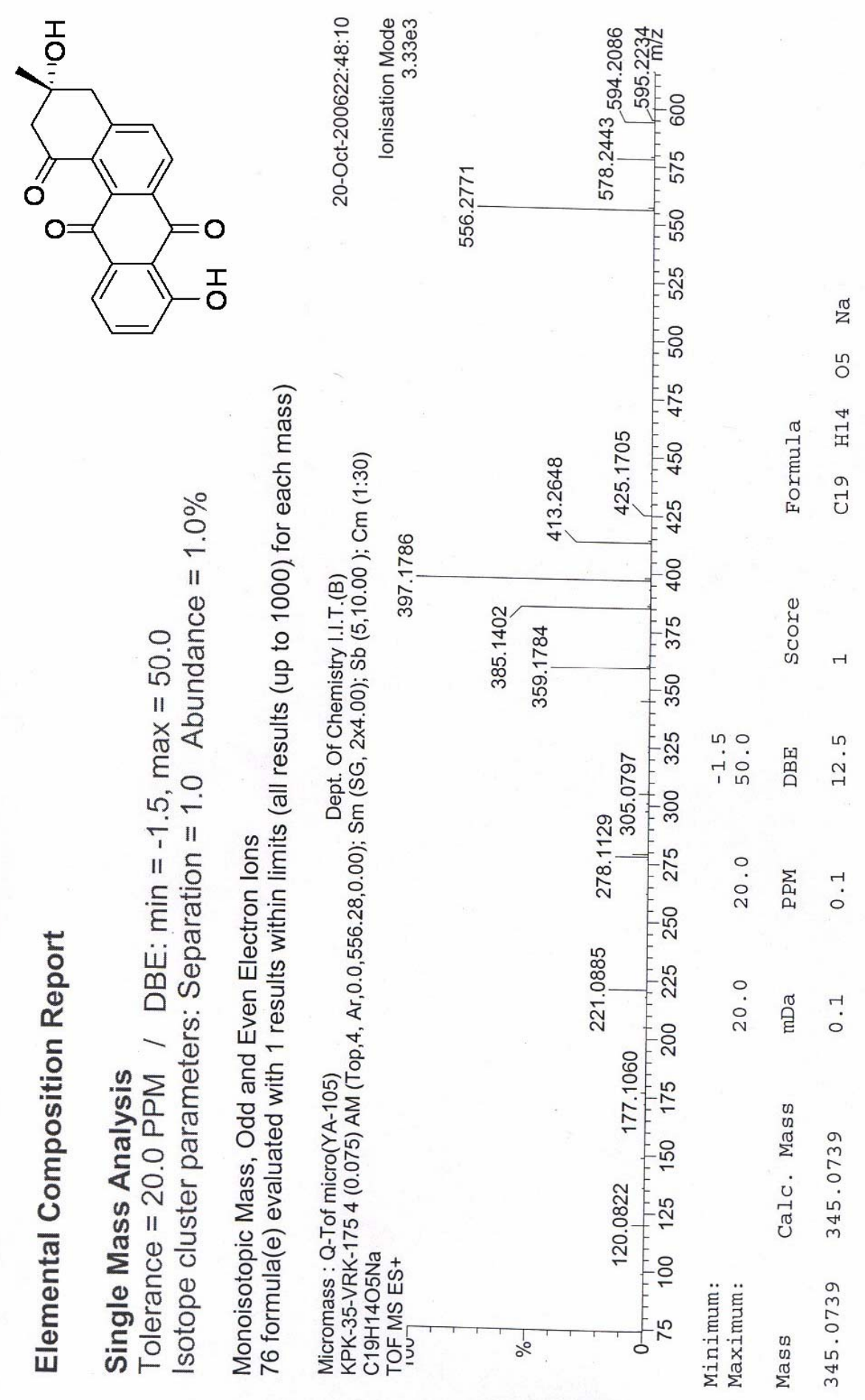


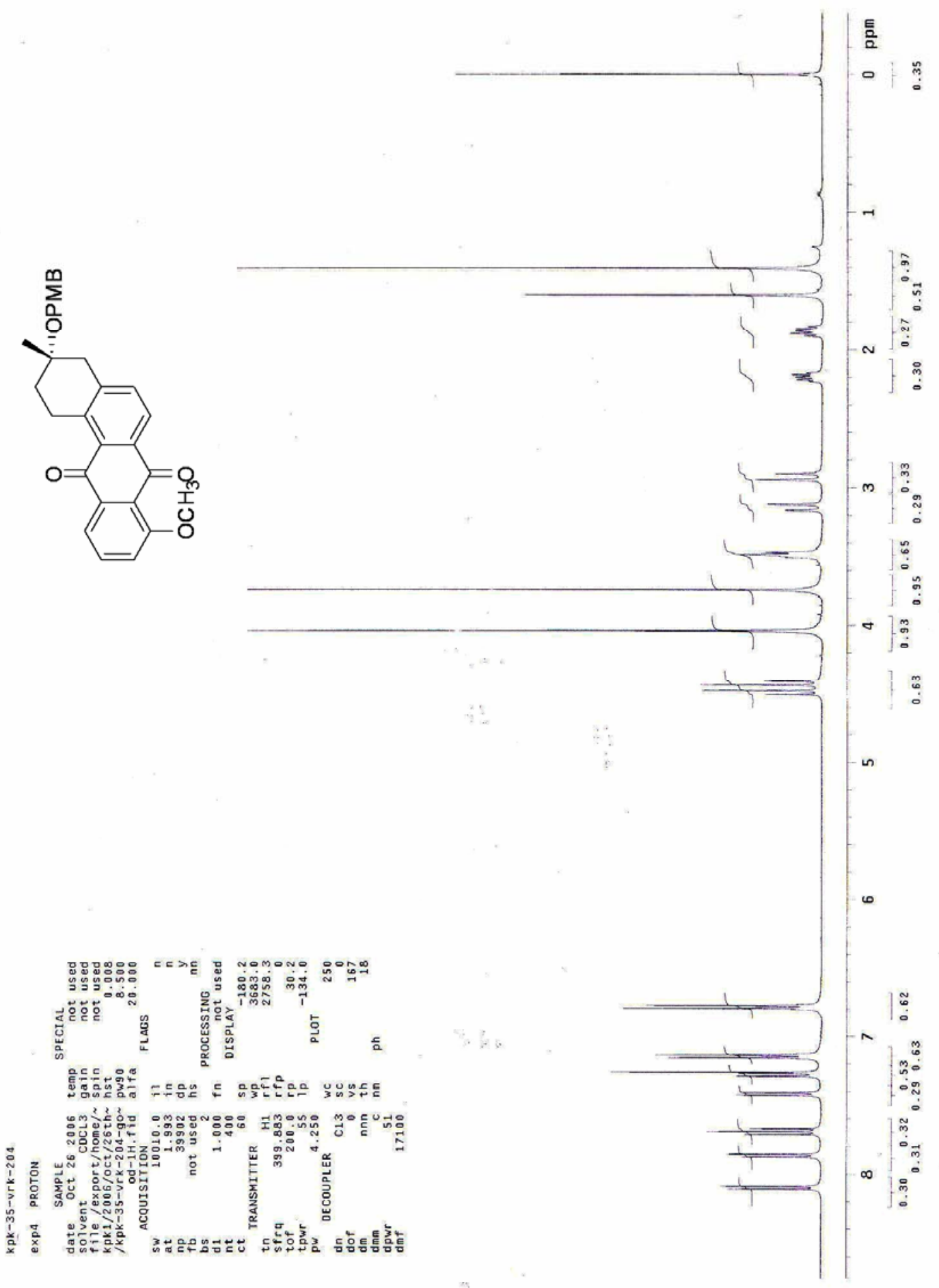




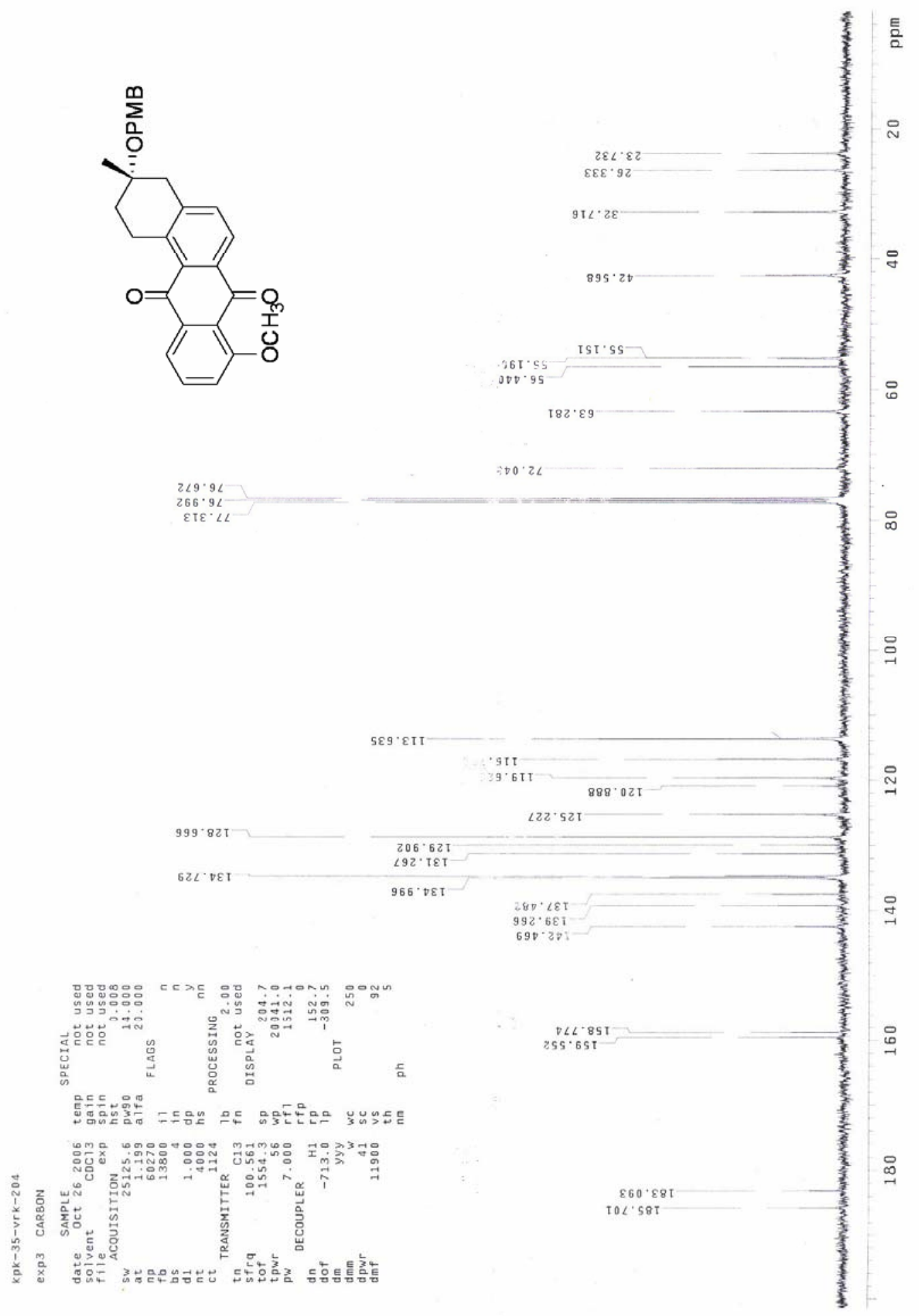




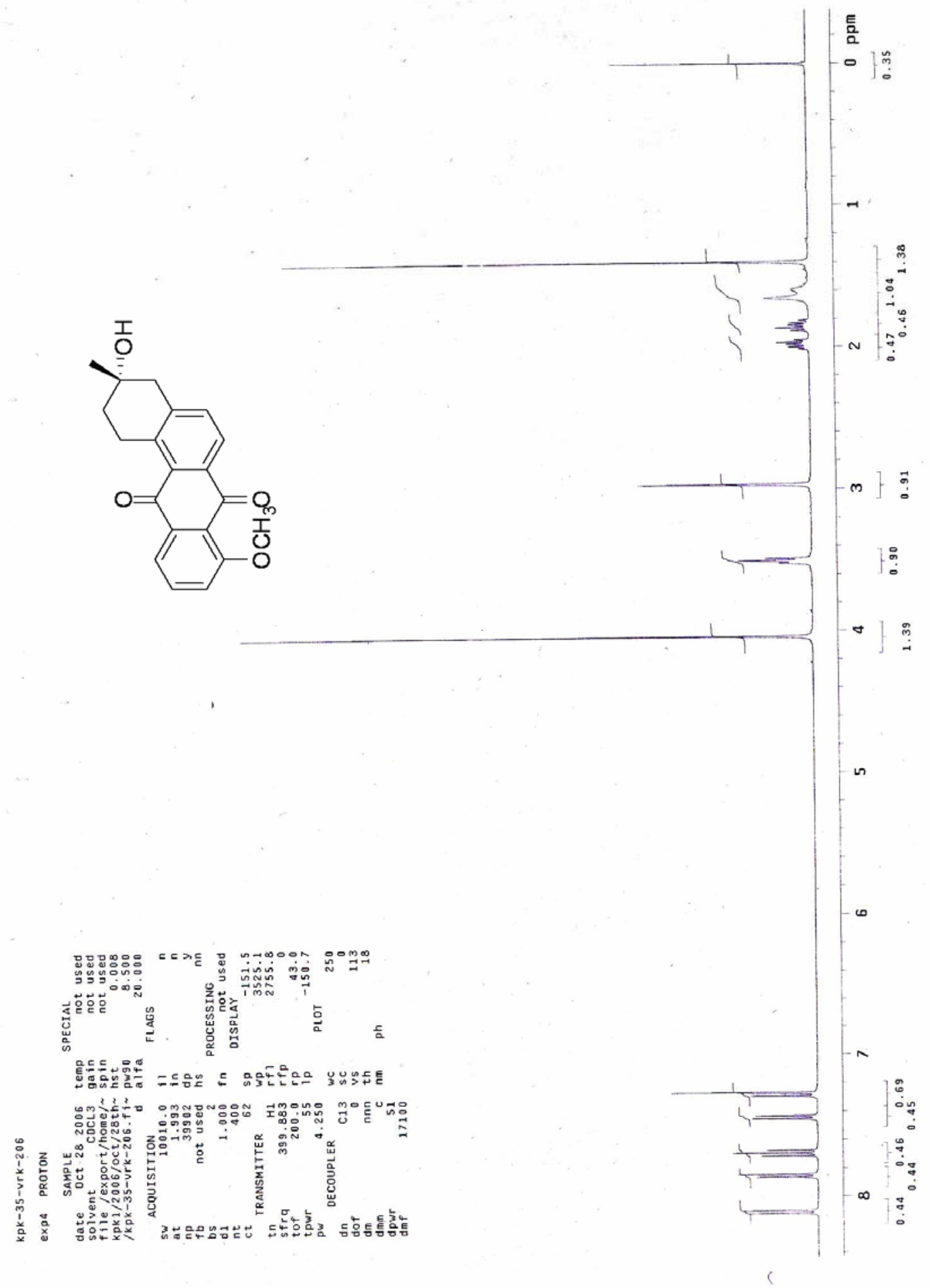




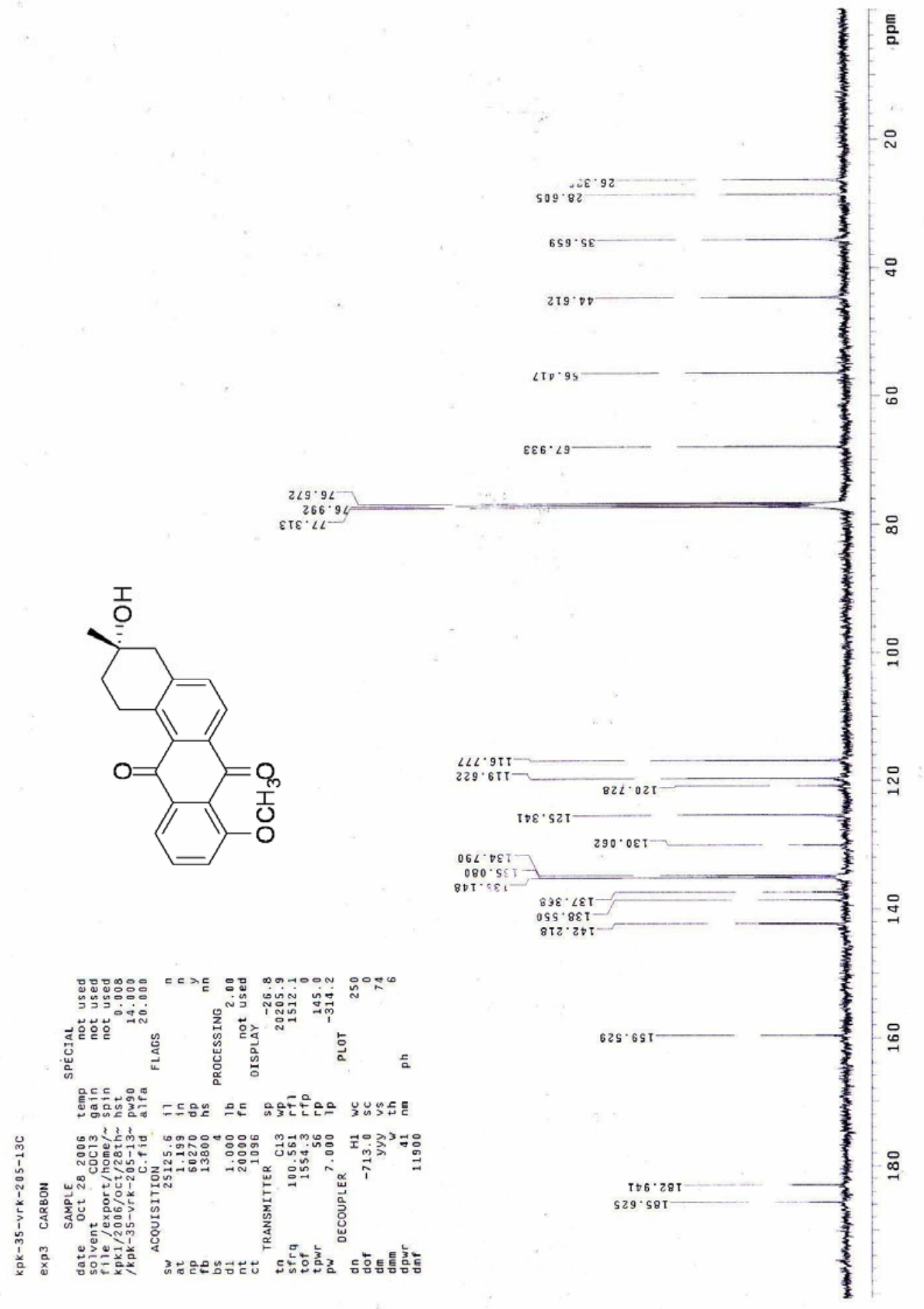




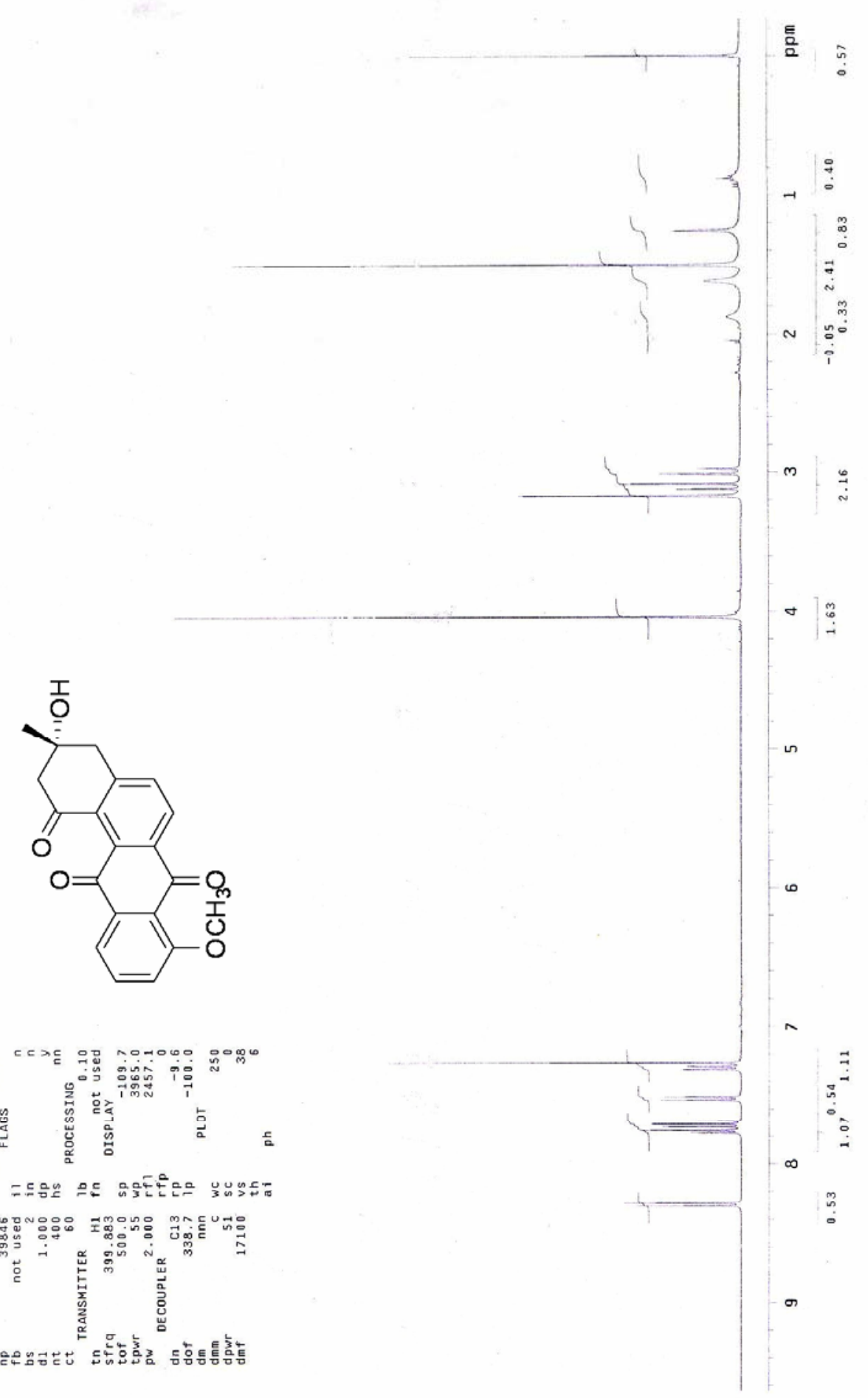




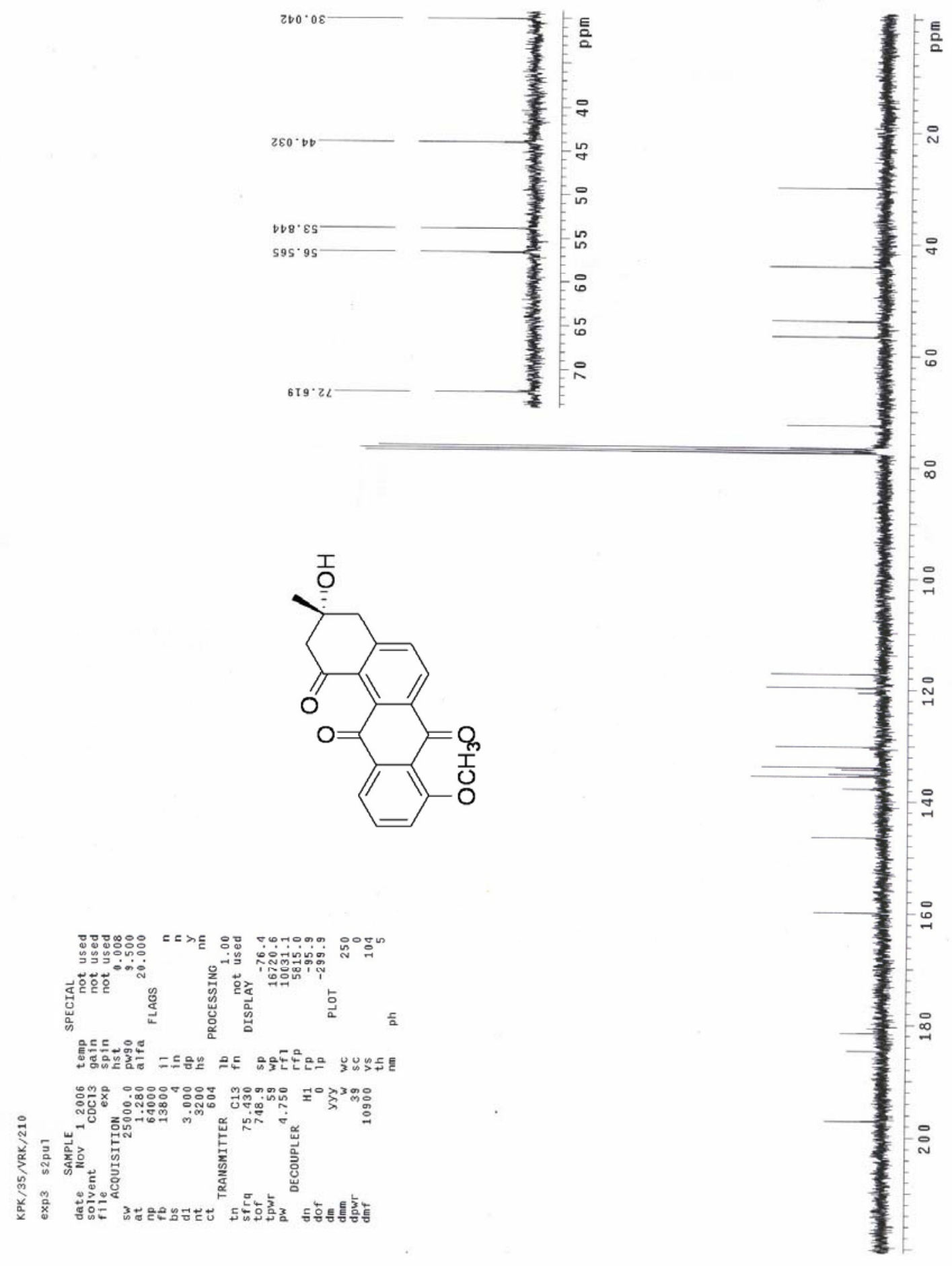




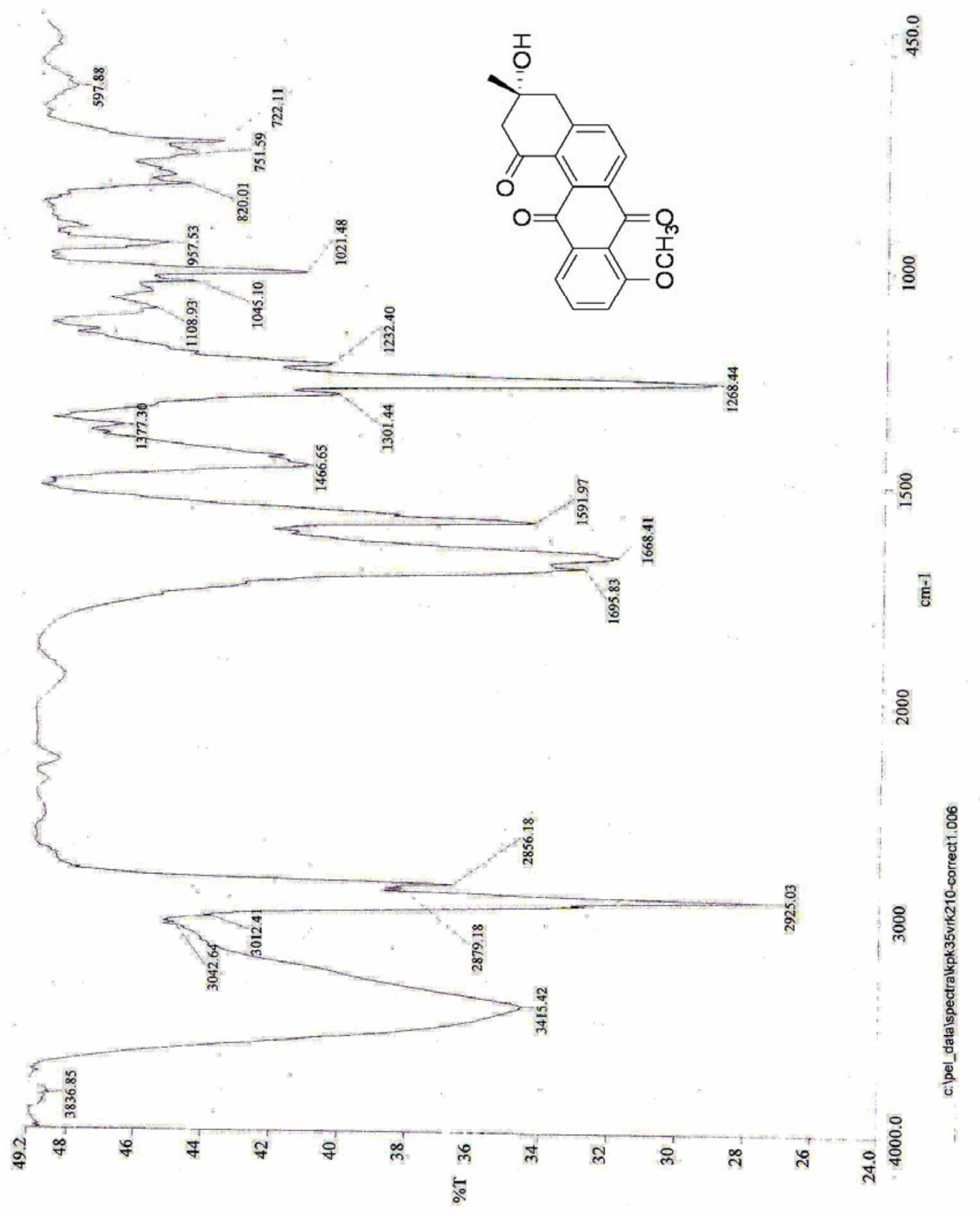



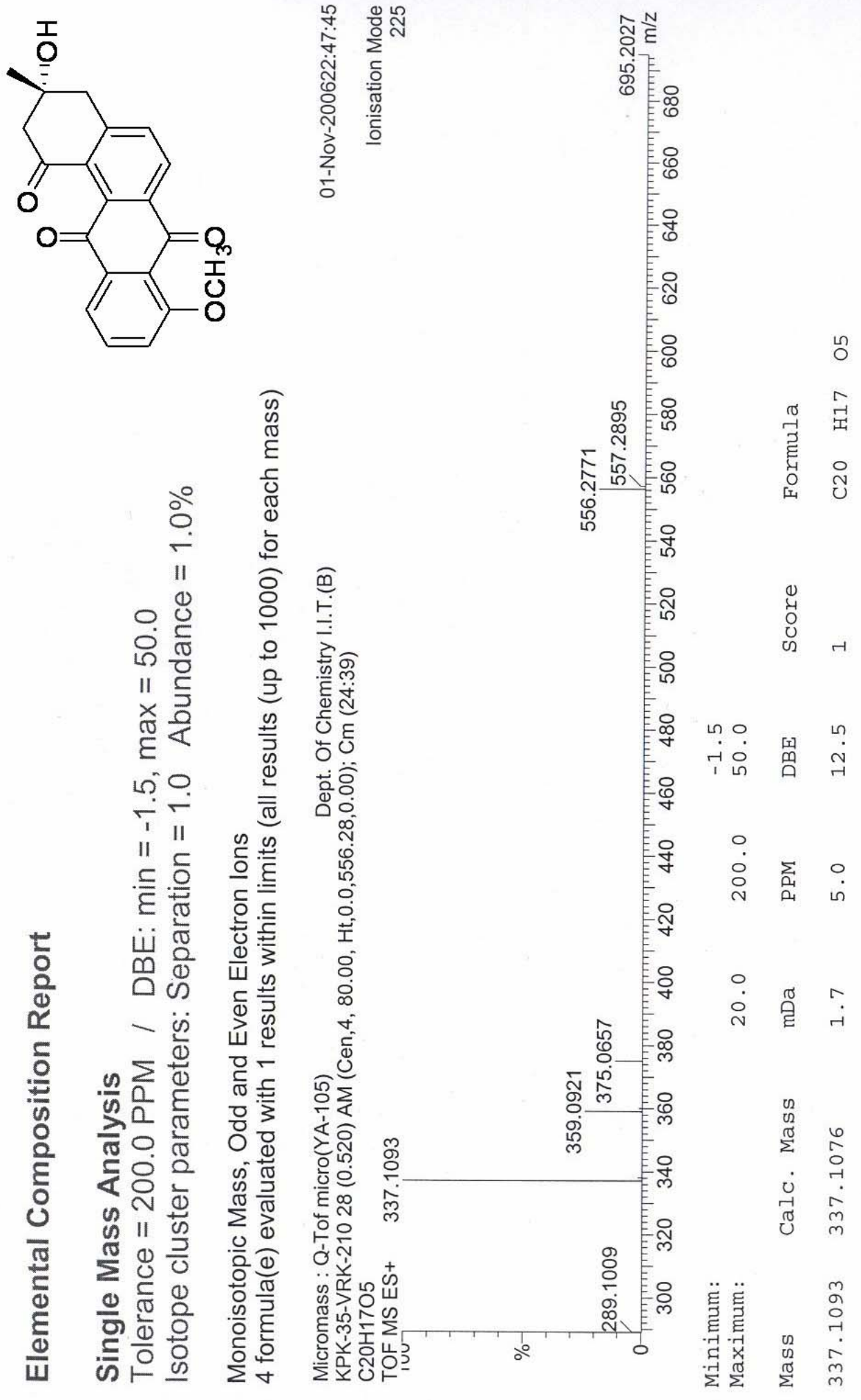